\title{
Rozdział 5 \\ Postawy kobiet i mężczyzn w różnym wieku wobec swego zdrowia
}

\subsection{Komponent poznawczy}

\subsubsection{Pojmowanie zdrowia przez kobiety i mężczyzn w różnym wieku (Krystyna Dzwonkowska-Godula)}

W wywiadach swobodnych pytano kobiety i mężczyzn w różnym wieku, jak rozumieją pojęcie „zdrowia”, co oznacza dla nich „być zdrowym”. Potoczne myślenie o zdrowiu, określane też mianem „świadomości zdrowotnej” ma wpływ na postępowanie ludzi wobec tego ich zasobu, „choć oczywiście nie pozwala całkowicie zrozumieć naszych zachowań” (Puchalski 1997: 7). Jak podkreślała nestorka polskiej socjologii medycyny, Magdalena Sokołowska, sposób pojmowania zdrowia zależy od wielu społecznych czynników, w tym społecznego statusu człowieka:

Słowa zdrowie i choroba nie mogą być [...] precyzowane w sposób uniwersalny czy statyczny. Mają one sens tylko wtedy, gdy dotyczą określonej osoby przebywającej w określonym środowisku fizycznym i społecznym [...]. W takim ujęciu zdrowie przestaje być jakimś monolitem, jakąś uniwersalną normą dla wszystkich ludzi. Zależy od płci, wieku, rodzaju pracy zawodowej, sytuacji rodzinnej - słowem jest to »zróżnicowane zdrowie«, pojęcie względne, mające różne znaczenie dla różnych ludzi (Sokołowska 1980: 126).

Tu skupiamy się na dwóch pierwszych - kluczowych w naszym przekonaniu - cechach społeczno-demograficznych, różnicujących sposób rozumienia zdrowia przez jednostki. Interesuje nas jednak nie biologiczny, a kulturowy wymiar płci i wieku (kulturowe koncepcje płci i wieku oraz „upłciowionego wieku” zawierające społeczne oczekiwania stawiane kobietom i mężczyznom zaliczanym do określonych kategorii wiekowych, dotyczące m.in. stosunku do zdrowia).

Uczestniczki i uczestnicy omawianego badania w podobny sposób określali zdrowie, definiowali je, używając tych samych określeń. 
Charakteryzowali zdrowie ogólnie, abstrakcyjnie jako idealny stan organizmu człowieka (brak choroby, dolegliwości, problemów zdrowotnych) lub konkretnie, odnosząc się nie tyle do pojęcia zdrowia, co „zdrowego człowieka". W tym drugim przypadku stosowali obiektywne i subiektywne kryteria bycia zdrowym. A zatem zdrowy człowiek w świetle wypowiedzi badanych normalnie funkcjonuje na co dzień, jest sprawny fizycznie, ma dobre wyniki badań lekarskich, nie potrzebuje stałej opieki lekarzy i nie musi przyjmować lekarstw, ponadto dobrze się czuje i jest w dobrej kondycji psychicznej.

Ta identyczność definicji zdrowia okazuje się jednak pozorna, gdy uwzględnimy $\mathrm{w}$ analizie postaw płeć oraz „upłciowiony wiek”. W pierwszej kolejności przyjrzymy się genderyzacji sposobu pojmowania zdrowia, porównując definicje podawane przez kobiety i mężczyzn.

Rozmówczynie w swoich określeniach zdrowia wydawały się wykazywać większą wiedzą medyczną, przejawiającą się w kompleksowym spojrzeniu na ludzki organizm - podkreślaniu znaczenia zdrowia fizycznego i psychicznego („ciała i ducha”), wymienianiu dysfunkcji konkretnych organów oraz chorób, których występowanie świadczy o braku zdrowia (np. choroby stawów, serca, problemy z układem pokarmowym) oraz wskazywaniu na dobre wyniki badań lekarskich jako wskaźnik dobrej kondycji organizmu. Wypowiedzi kobiet świadczyły o tym, że są one oswojone z medyczną terminologią: „Brak takich wskaźników typowo bólowych, że coś ci dolega” (KSR_2_41); „Uwzględniłabym aspekt i ten fizyczny, somatyczny i ten psychiczny. [...] brak no, znowu jakichś poważnych dolegliwości, dysfunkcji" (KSR_5_47); „Podatność na różne rzeczy, na różnego rodzaju wirusy, bakterie, zarazki” (KSR_1_38). Może to wynikać z częstszych kontaktów kobiet (w porównaniu z mężczyznami) z lekarzami oraz szukania informacji dotyczących zdrowia także $\mathrm{w}$ innych (nieprofesjonalnych, alternatywnych) źródłach wiedzy jak Internet (Nowak, ChalimoniukNowak 2015: 38). Wiąże się to z ich rolą "domowego lekarza”, zapewnianiem przez nie opieki zdrowotnej dzieciom i innym członkom rodziny (Tobiasz-Adamczyk 200o: 61). W związku z tym „muszą” one znać określone symptomy chorobowe, rozpoznawać niepokojące objawy, umieć opisać je lekarzowi. Ponadto wskazuje się, że większe zainteresowanie kobiet własnym stanem zdrowia i ich większa świadomość zdrowotna wynika z procesu socjalizacji: „w okresie dojrzewania rodzice poświęcają więcej uwagi problemom dziewczynek niż chłopców. Powoduje to, że dziewczęta są bardziej wyczulone na wszelkie dolegliwości" (Synowiec-Piłat 2002: 90) oraz zmiany zachodzące w ich ciałach (Ostrowska20o6: 117). Co więcej, zdaniem A. Buczkowskiego, opisującego proces medykalizacji kobiecego ciała, kobiety „postrzegane 
przez pryzmat swoich organów reprodukcyjnych” podlegają „stałemu dozorowi medycznemu" (Buczkowski 2005: 144).

Uczestniczki badania więcej miejsca niż mężczyźni poświęcały w swoich wypowiedziach zdrowiu psychicznemu, bardziej szczegółowo je opisywały, wymieniając problemy związane z depresją, odczuwaniem smutku, rozdrażnienia, zdenerwowania, braku sensu itp. Pojawiały się tu uwagi, że zdrowie fizyczne (prawidłowe funkcjonowanie organizmu, jego układów i narządów, brak objawów chorobowych) nie zawsze idzie w parze ze zdrowiem psychicznym i że pożądana jest równowaga pomiędzy oboma wymiarami zdrowia: „Przede wszystkim (zdrowie - przyp. aut.) z naukowego punktu widzenia są to wyniki badań, ale nie zawsze, czasem wyniki badań są super, a człowiek chodzi i mówi, jaki jest schorowany, jak mu jest źle w życiu, że wszystko jest bez sensu, że nie wiadomo, co tam się dzieje" (KM_5_28). Miarą prawidłowo funkcjonującej sfery „duchowej” było dla respondentek poczucie życiowej równowagi, przekonanie jednostki, że jej się „układa w życiu”, brak zmartwień, optymizm, czyli ogólnie rzecz biorąc zadowolenie z życia, a także zadowolenie z siebie, energia życiowa oraz normalne relacje $\mathrm{z}$ innymi ludźmi. Mężczyźni z reguły ograniczali się do stwierdzenia, że definiując zdrowie, należy także uwzględniać kwestię psychiki, ewentualnie utożsamiali zdrowie psychiczne $\mathrm{z}$ byciem zadowolonym $\mathrm{z}$ siebie i z życia, chęcią do życia, a także sprawnością umysłową. Zwraca uwagę fakt, że używanie pojęcia „sprawności" (przede wszystkim fizycznej, ale i psychicznej) do opisu zdrowego człowieka jest charakterystyczne dla mężczyzn i odpowiada stereotypowi męskości.

To przywiązywanie wagi przez kobiety do zdrowia psychicznego i równowagi „duch-ciało” wiązać można ze stwierdzaną w badaniach naukowych subiektywnie ocenianą gorszą kondycją psychiczną przedstawicielek płci żeńskiej (CBOS 2012a: 93, 96) oraz ich większą podatnością na takie choroby psychiczne jak depresja czy zaburzenia lękowe (Tobiasz-Adamczyk 2000: 124; Ostrowska 2006: 120; Frąckowiak-Sochańska 2011: 396). Wskazuje się, że wynika to z doświadczanych przez nie społecznych stresów związanych m.in. z obciążeniem obowiązkami domowymi, problemami finansowymi (feminizacja ubóstwa), niedocenianiem ich pracy domowej i brakiem satysfakcjonującej gratyfikacji za pracę zawodową (ograniczony awans zawodowy, niższe zarobki w porównaniu z mężczyznami), mniejszymi możliwościami samorealizacji (Ostrowska 2006: 120). Jak stwierdza Antonina Ostrowska: „kobiety częściej ulegają depresji, ponieważ mają ku temu powody. Są one związane głównie z niekorzystnym układem ról społecznych i strukturą szans w społeczeństwie" (Ostrowska 2006: 120). 
Częstsze włączanie przez kobiety kwestii psychiki do ogólnych definicji zdrowia oraz wskazywanie przez nie różnych, także negatywnych aspektów kondycji psychicznej może również wynikać z faktu, że w procesie socjalizacji rozwijają one większą $\mathrm{w}$ porównaniu $\mathrm{z}$ mężczyznami umiejętność dzielenia się $\mathrm{z}$ otoczeniem swoimi problemami i szukania wsparcia, także w przypadku dolegliwości natury psychicznej (Ostrowska 2006: 121; Tobiasz-Adamczyk 2000: 127). Umieją je nazwać i mówić o nich otwarcie. W tradycyjnym modelu męskości wszelkie zaburzenia i dolegliwości, tym bardziej sfery „duchowej” traktowane są jako słabość, nie wspomina się o nich. Uczestniczący w badaniu mężczyźni, choć uwzględniali psychikę w swoich opisach zdrowia, utożsamiali je jednak raczej ze sprawnością fizyczną.

Kobiety w swoich definicjach zdrowia, gdy odwoływały się do „sprawności funkcjonalnej" (Sokołowska 1980: 126) rzadko wspominały o pracy zawodowej, odnosiły się raczej do możliwości wykonywania codziennych czynności, „robienia, co się chce”, sprawnego funkcjonowania bez ograniczeń dotyczących odżywiania się, poruszania się, także uprawiania sportu: „Robię, nie narzekam, nie meczę się" (KSR_15_62); „No być zdrowym, to nie mieć żadnych dolegliwości i móc być aktywnym, latać, biegać i bez jakichś ograniczeń" (KST_8_70). W kobiecych definicjach zdrowia pojawiło się określenie „mieć siłę” - do życia, do wstania z łóżka, do działania - odnoszące się zarówno do siły fizycznej, jak i chęci do życia:

No właśnie być zdrowym do pracy, mieć siłę do wstania rano, cieszenia się życiem. Mieć po prostu siłę do życia (KST_10_71). Czyli to, że człowiek wstaje rano bez problemu. [...] znaczy nie ma problemów, może zrobić to, co chce, czyli ma siłę, możliwość zrobienia bez problemu, np. no nie wiem pójść pograć w piłkę, na basen i wraca powiedzmy z tego basenu i ma siłę coś tam jeszcze zrobić (KM_2_24).

Traktowanie „siły” jako wyznacznika zdrowia przez kobiety mogłoby świadczyć o rzeczywistej „słabości” kobiecej płci albo poczuciu takiej słabości w obliczu obciążenia wieloma obowiązkami - żeby im podołać, potrzeba siły. Ponadto w kobiecych definicjach pojawiły się wskazania, (które nie pojawiły się w wypowiedziach mężczyzn biorących udział w badaniu), że zdrowie oznacza samodzielność, niezależność od innych w codziennej aktywności oraz możliwość pomagania innym - „bycie użyteczną dla innych” (KST_6_69). Badane obawiały się, że w związku ze złym stanem zdrowia mogłyby potrzebować wsparcia, podczas gdy ich społeczne kobiece role wiążą się z służeniem pomocą, a nie korzystaniem $\mathrm{z}$ niej.

Zapytani mężczyźni nieco częściej niż biorące udział w badaniu kobiety odwoływali się $\mathrm{w}$ tworzonych przez siebie definicjach zdrowia 
do kryterium normalnego codziennego funkcjonowania, przy czym wskazywali oni na możliwość bycia aktywnym zawodowo oraz uprawiania sportu czy realizowania innego hobby:

Bycie zdrowym [...] to można wtedy wszystko. To znaczy pracować, nie wiem, biegać, nie wiem, skakać, wszystko (MM_9_30). Możliwość rozwoju własnych hobby, zainteresowań [...]. Jeżeli pozwala nam na rozwijanie się, robienie tego, czego chcemy również w sportach, to uważam, że to jest ogólne zdrowie (MSR_4_40). Być zdrowym. Pracować, urzędować, i zabawić się i maszerować i zwiedzać, to być zdrowym (MST_12_72).

Charakterystyczne dla uczestniczących w badaniu mężczyzn określanie zdrowia przez zawodową aktywność przejawiało się także w podkreślaniu przez nich, że zdrowy człowiek nie bierze zwolnień lekarskich - pracuje i zarabia.

Wskazywanie różnych aspektów „sprawności funkcjonalnej” jako przejawu zdrowia przez kobiety i mężczyzn może wynikać z patriarchalnej dychotomii płci prywatne-publiczne. Kobiety mają być zdrowe, by wypełniać swoje role domowe, muszą być same sprawne, by nie obciążać sobą innych, a wręcz przeciwnie, móc im jak najdłużej pomagać (np. jako babcie w opiece nad wnukami). Mężczyznom z kolei zdrowie jest potrzebne przede wszystkim do funkcjonowania w sferze publicznej, co wiąże się z rolą żywiciela rodziny, ewentualnie, by móc rozwijać także inne formy pozadomowej aktywności, ukierunkowanej na zaspokojenie ich własnych potrzeb (rozwijanie zainteresowań).

Uczestniczący w badaniu mężczyźni w swoich definicjach zdrowia odwoływali się także do innego aspektu kulturowego modelu męskości - sprawności fizycznej. Wyznacznikiem zdrowia była dla nich dobra kondycja fizyczna, przejawiająca się w zdolności do różnego rodzaju aktywności ruchowej i sportowej. O byciu zdrowym świadczy w ich przekonaniu np. możliwość przebiegnięcia określonego odcinka, podniesienia ciężaru, wykonania gimnastycznego ćwiczenia:

Potrafić też bez problemu przebiec i wykonać podstawowe ćwiczenia fizyczne, które robiło się na WF-ie w sposób właściwy i w wymaganej liczbie powtórzeń (MM_5_26). Być wysportowanym (MSR_13_6o). Ja mam dobrą kondycję, ja to wytrzymuję, [...] jeżeli w swoim wieku jeszcze potrafię jeszcze wiele rzeczy, właśnie na tym parkiecie (grając w siatkówkę - przyp. aut.) sobie pozwolić, to chyba znaczy, że jestem zdrowy. No w miarę zdrowy (MST_5_64).

Zdrowie - rozumiane jako fizyczna siła i sprawność - przejawia się także w seksualnej aktywności mężczyzny: „No być zdrowym to znaczy być sprawnym. Sprawnym fizycznie i psychicznie. Już nie mówiąc o takich sprawach intymnych, jak tam seks czy coś tam tego rodzaju, ale to 
też ma wpływ" (MST_13_77). Zdrowie mężczyzny, zgodnie z patriarchalnym modelem płci, utożsamiane jest zatem $z$ fizyczną siłą, wytrzymałością oraz witalnością.

Gdy w analizie wypowiedzi kobiet i mężczyzn uwzględnimy wiek, okazuje się, że osoby młode, w średnim wieku i stare różnią się w sposobie pojmowania zdrowia. Przyjrzyjmy się najpierw definicjom zdrowia tworzonym przez respondentki w trzech kategoriach wiekowych.

W badanej zbiorowości kobiet młode uczestniczki wyróżniały się utożsamianiem zdrowia $\mathrm{z}$ dbaniem o nie, działaniami na jego rzecz. W świetle ich definicji zdrowy jest człowiek, który dba o zdrowie, prowadzi zdrowy styl życia. Badane zwracały uwagę nie tylko na takie prozdrowotne działania jak odpowiednie odżywianie się, czy aktywność fizyczna, ale także działania szkodzące zdrowiu, np. stosowanie używek. Wypowiedzi te świadczą o przekonaniu części młodych kobiet, że o „jakości” zdrowia jako zasobu człowieka decyduje on sam i jego wybory dotyczące stylu życia: „Bycie zdrowym fizycznie to wiadomo posiadanie dobrych wyników, aktywny tryb życia, zdrowy tryb życia” (KM_10_30); „[...] to jest podejście [...]. Zdrowie dla mnie łączy się ze zdrowym trybem życia i z odżywianiem, odpowiednimi produktami" (KM_5_28). Taki sposób pojmowania zdrowia przez młode kobiety wynikać może z faktu, że dorastały one w kulturze kultu zdrowia, mody na zdrowy styl życia oraz propagowanej przez media indywidualnej odpowiedzialności za zdrowie. Stąd młodzi - dotyczy to również mężczyzn - są bardziej niż osoby starsze podatni na ideologię healthismu, zgodnie z którą to jednostka ponosi odpowiedzialność za stan swojego zdrowia, a zdrowie jest nadrzędną wartością, której podporządkowane powinny być wszystkie sfery życia (Crawford 1980 za: Borowiec, Lignowska 2012). Pociąga to za sobą wymóg zdrowego stylu życia i podejmowania prozdrowotnych działań.

Charakterystyczne dla młodych uczestniczek badania było także stosunkowo częstsze niż w przypadku starszych respondentek podkreślanie znaczenia zdrowia psychicznego $\mathrm{w}$ definiowaniu zdrowego człowieka. Tylko w ich wypowiedziach pojawiły się uwagi dotyczące wpływu kondycji psychicznej jednostki na jej relacje z innymi ludźmi oraz konieczności korzystania z usług specjalisty, by określić stan zdrowia psychicznego:

Być zdrowym to czuć się dobrze, nie zagrażać sobie ani innym [...]. No tutaj bardziej mi przyszło do głowy jakieś zdrowie psychiczne, tak? No bo czuć się dobrze i jednocześnie musieć co rano dźgnąć kogoś nożem, no to już niekoniecznie jest zdrowe. Więc mam na myśli właśnie to, żeby funkcjonować sobie jak gdyby dobrze, ale jednocześnie nie ingerować w przestrzeń innych osób (KM_4_27). Zdrowie, to też zdrowie psychiczne, tego niestety sami sobie nie zbadamy (KM_2_24). 
Młode kobiety podkreślały, że określając kogoś mianem zdrowego, należy brać pod uwagę nie tylko dolegliwości i choroby ciała, ale także psychiki. Z kolei z wypowiedzi uczestniczek badania w średnim wieku oraz najstarszej kategorii wiekowej można wywnioskować, że dla części z nich pozytywny stan psychiczny jest konsekwencją dobrego zdrowia fizycznego: jeśli nic ci nie dolega, sprawnie funkcjonujesz, nie męczysz się, „masz siłę”, to nie narzekasz i cieszysz się życiem: „Jak człowiekowi nic nie dolega to myślę, że jest w porządku, ok. [...] Lepszy humor jest" (KSR_14_53); „No i jest radosny człowiek, nic nie dolega” (KST_3_65). $\mathrm{Z}$ drugiej strony, stare respondentki zwracały uwagę, że psychika odgrywa ważną rolę $\mathrm{w}$ leczeniu chorób i radzeniu sobie z licznymi w ich wieku dolegliwościami, nie pozwala „poddać się," bo „jak jest chęć życia, to i zdrowie jest" (KS_1_64).

To stosunkowo częstsze wskazywanie przez młode osoby (zaobserwowane także $w$ grupie mężczyzn) znaczenia zdrowia psychicznego dla funkcjonowania jednostki może być efektem ich większej świadomości i wiedzy w porównaniu z osobami starszymi na temat problemów psychicznych dokuczających współczesnym ludziom. Młodzi dorastali i funkcjonują $\mathrm{w}$ świecie, $\mathrm{w}$ którym negatywne skutki stresu, problemy z układem nerwowym, depresją i innymi chorobami psychicznymi są nagłaśniane przez media, oferuje się różnego rodzaju medykamenty o działaniu uspokajającym, poprawiającym nastrój, bez których „nie można się obejść", intensywnie rozwijają się usługi psychoterapeutyczne w różnych formach. Ponadto „społeczeństwo ryzyka” sprzyja pojawianiu się problemów psychicznych w związku z rosnącym poczuciem niepewności, lęku, nieradzenia sobie $\mathrm{z}$ wymogami rynku pracy, konkurencji itp.

Młode rozmówczynie zauważały, że obiektywne, „naukowe” stwierdzenie dobrego stanu zdrowia nie zawsze idzie w parze z subiektywnym poczuciem bycia zdrowym. Tym samym podkreślały złożoność i trudność określenia zdrowia, które wymaga np. uwzględnienia zdrowia fizycznego i psychicznego. Ponadto według młodych uczestniczek badania nie wszystkie dolegliwości i kłopoty zdrowotne oznaczają brak zdrowia i bycie chorym. Oznaką braku zdrowia jest ich zdaniem poważna lub przewlekła choroba, wymagająca specjalistycznego leczenia i utrudniająca życie:

Dla mnie niezdrowy, to już jak by ktoś miał, nie wiem, ciężką faktycznie taką chroniczną, trudną do wyleczenia chorobę, to jest [...]. Ale ja siebie uważam generalnie za osobę zdrową, mimo że tam mam różne hormonalne, czy miałam bardziej, problemy, takie typowo kobiece (KM_12_34). (Być zdrowym to - przyp. aut.) nie być pod opieką jakiegoś specjalisty, powiedzmy na stałe (KM_8_29). 
Uczestniczki badania $\mathrm{w}$ średnim wieku równie często definiowały zdrowie poprzez brak choroby i dobre samopoczucie. Natomiast stare respondentki wydawały się bardziej zdawać na medycynę profesjonalną w ocenie stanu zdrowia, traktując lekarską diagnozę czy wyniki badań jak wyrocznię. To relatywnie duże „zaufanie” do lekarzy przedstawicielek tej kategorii badanych potwierdzają wyniki sondażu przeprowadzonego na reprezentatywnej próbie Polaków, pokazujące że kobiety w wieku 60 lat i więcej traktują lekarzy jako autorytety w sprawie zdrowego stylu życia (Nauka w Polsce 2012). Ta „uległość wobec autorytetu” starych kobiet może być traktowana jako wyraz ich „kobiecej” - ukształtowanej w wyniku patriarchalnej płciowej socjalizacji - większej skłonności do konformizmu oraz „lokowania się” w relacji władzy na podporządkowanej pozycji.

Jeżeli chodzi o uczestniczki badania w średnim wieku, to tylko w ich grupie znalazła się respondentka, która wskazywała, że o zdrowiu człowieka „informuje” jego wygląd: „myślę że ten dobry wygląd świadczy o tym, że jest się zdrowym, bo ludzie chorzy, no jest też oznaka [...] po wyglądzie, że coś się tam dzieje" (KSR_14_53). Zwraca uwagę określenie „dobry wygląd”, który w ustach kobiety i w odniesieniu do kobiety, i to w średnim wieku (nie młodej - „z definicji” atrakcyjnej) może wskazywać na zinternalizowane oczekiwanie, że trzeba „dobrze wyglądać". Stwierdzenie takie nie znalazło się w wypowiedziach młodych uczestniczek badania, które ze względu na wiek mają prawdopodobnie poczucie, że ich młody wygląd świadczy o ich dobrym zdrowiu. Nie wspominały o tym także stare kobiety, zdające sobie sprawę, że upływający czas i odczuwane, związane $\mathrm{z}$ wiekiem dolegliwości odbijają się na ich wizerunku.

To, co zwraca uwagę w definicjach zdrowia tworzonych przez kobiety w średnim wieku, to stosunkowo częste utożsamianie bycia zdrowym z brakiem bólu. Ból był przez nie traktowany jako sygnał ostrzegawczy, informujący, że coś złego dzieje się w organizmie i że trzeba zareagować - pójść do lekarza. Był postrzegany jako ograniczenie w normalnej aktywności i wiązany często z problemami z układem pokarmowym:

No tak prozaicznie, że cię nic nie boli [...], brak takich wskaźników typowo bólowych, że coś ci dolega i nie możesz ruszyć się z domu (KSR_2_41). Ja myślę, że oznaką, że coś się dzieje to jest właśnie ból, jeżeli ten ból nie ustępuje, to idziemy, bo nie możemy sobie poradzić, idziemy do lekarza no i jest tam jakaś tego konsekwencja. Bo chyba nie ma bólu bez jakichś przyczyn chorobowych (KSR_14_53).

Stwierdzenia te świadczą o wspominanym wsłuchiwaniu się kobiet we własny organizm, wyczuleniu na symptomy choroby, związanym z ich 
większą w porównaniu z mężczyznami świadomością zdrowotną. Wynika to także $\mathrm{z}$ osobistych doświadczeń respondentek w średnim wieku, zmagających się z różnymi dolegliwościami bólowymi. Młodych kobiet w związku z lepszą kondycją organizmu ten problem nie dotyczył, czy też dotyczył w mniejszym stopniu, stąd też rzadziej pojawiał się w ich definicjach zdrowia (zdrowie definiowane było przez nie przede wszystkim jako brak problemów zdrowotnych i chorób, nie bólu). Z kolei stare respondentki wydawały się być z bólem oswojone, dlatego też rzadziej o nim wspominały, opisując zdrowie. Jak stwierdziła jedna z nich, „W moim wieku, to jest takie powiedzenie, że jak się wstaje rano i coś boli, to znaczy, że żyję jeszcze" (KST_3_65). Jeżeli wspominały one o bólu, to przede wszystkim o bólu żołądka czy brzucha.

To, co łączyło definicje zdrowia podawane przez kobiety w średnim wieku i stare, to właśnie wskazywanie braku dolegliwości i schorzeń układu pokarmowego oraz możliwości jedzenia tego, co się chce jako oznaki bycia zdrowym: „Być zdrowym to znaczy, że jem wszystko, nic mnie nie boli i robię wszystko (KSR_15_62); „Nie mam żadnych dolegliwości, że nagle zjem coś i umieram na żołądek [...]” (KSR_9_54); „Móc jeść wszystko, co ci się podoba, a nie tylko sałatkę i suchy chleb z masełkiem" (KST_7_7o). Wskazywać to może na doświadczane przez nie, związane $\mathrm{z}$ wiekiem, problemy zdrowotne i ograniczenia w sposobie odżywiania. Jak pokazuje analiza działań prozdrowotnych (zaprezentowana w dalszej części książki), fakt, że młode respondentki w ogóle o tym nie wspominały, może wynikać nie tylko z lepszej kondycji ich organizmu, $\mathrm{w}$ tym układu pokarmowego, ale także z większej wiedzy na temat właściwej diety, zasad odżywiania się itp.

Charakterystyczne dla definicji zdrowia podawanych przez stare uczestniczki badania było określanie go poprzez brak konkretnych chorób, przede wszystkim związanych $\mathrm{z}$ określonymi narządami, np. układem kostno-stawowym, sercem czy też wspominanym układem pokarmowym. Badane odnosiły się przede wszystkim do zdrowia fizycznego, które w ich wieku jest przedmiotem troski i opieki lekarskiej. Nieliczne z nich traktowały samopoczucie jako kryterium zdrowia, zdawały się raczej na diagnozę lekarską w określaniu kondycji organizmu. To zaufanie starszych do medycyny naprawczej może mieć charakter pokoleniowy. Przekonanie, że to nauka i instytucjonalna służba zdrowia jest remedium na choroby człowieka, wiąże się z biomedycznym modelem zdrowia, dominującym do lat siedemdziesiątych XX wieku, gdy „odkryto” znaczenie stylu życia i społeczno-kulturowych uwarunkowań zdrowia (Ostrowska 1998; 2009). Jeżeli stare respondentki odwoływały się do subiektywnych kryteriów, to dobre samopoczucie nie było określane przez nie w kategoriach pozytywnych, jak w przypadku respondentek młodych i w średnim 
wieku, a utożsamiane z brakiem dolegliwości: zdrowy człowiek nie tyle „dobrze się czuje”, co nie czuje bólu, dyskomfortu (nic go nie boli, nie myśli o zdrowiu, bo nie odczuwa żadnych dolegliwości).

Uczestniczki badania w trzech kategoriach wiekowych różniły się także $\mathrm{w}$ rozumieniu sprawności fizycznej jako kryterium zdrowia. Młode rozmówczynie utożsamiały ją ze sprawnym poruszaniem się, uprawianiem sportu (dostosowanego do „możliwości organizmu”), zdolnością do wysiłku fizycznego: „I mieć takie warunki fizyczne, żeby zrobić to, na co ma się ochotę, wycieczki rowerowe czy piesze. Znać możliwości swojego organizmu" (KM_9_30). W wypowiedziach badanych w średnim wieku zwracało uwagę kojarzenie sprawności z „niemęczeniem się" w trakcie wykonywania codziennych czynności i wysiłku fizycznego związanego np. z wejściem na schody. Stare uczestniczki badania wskazywały na „bycie w ruchu” na co dzień, choć zdaniem jednej z badanych miarą zdrowia (utożsamianego ze sprawnością ruchową czy fizyczną) jest także aktywność rekreacyjna (chodzenie po górach, piesze wycieczki): „Że nie mam na przykład takich ograniczeń, że nie mogę kawałek pobiec, że nie mogę wsiąść na rower, że nie mogę na jakąś górę wejść, bo wchodzę na różne góry. Nie mam takich ograniczeń w tej chwili jeszcze" (KST_4_66).

Stare respondentki wyróżniały się na tle młodszych uczestniczek badania, wskazując w swoich definicjach zdrowia na znaczenie samodzielności, niezależności od innych w codziennych domowych obowiązkach, higienie osobistej. To w tej kategorii badanych znalazła się kobieta definiująca zdrowie poprzez możliwość „bycia użytecznym”, pomocy innym, aktywne uczestnictwo $\mathrm{w}$ życiu bliskich osób. W wypowiedziach tych znajduje wyraz przekonanie, że rolą kobiety jest pomagać i służyć bliskim, a nie samej takiej pomocy oczekiwać. Kobiety mają być zdrowe nie tyle dla siebie, co dla innych, by nie absorbować ich swoją osobą, a wręcz przeciwnie, być do dyspozycji.

Różnice w definiowaniu zdrowia zaobserwowano także, analizując wypowiedzi mężczyzn $\mathrm{z}$ uwzględnieniem ich wieku. Tylko młodzi respondenci wskazywali na związek zdrowia $\mathrm{z}$ wyglądem. W ich przekonaniu zdrowy człowiek wygląda „dobrze” czy „normalnie”: „Kiedy człowiek wygląda i zachowuje się normalnie i nie odczuwa przy tym żadnego bólu, czyli nie nękają go żadne dolegliwości, to znakiem tego, że jest zdrowy" (MM_3_22); „Dobrze wyglądać też. Zdrowie to jest brak nadwagi [...]” (MM_10_31). Zwrócenie przez nich uwagi na kwestię „dobrego wyglądu” jest przejawem opisywanej wcześniej (patrz rozdział dot. postaw wobec wyglądu) androgynizacji postaw młodych ludzi wobec wyglądu - młodzi mężczyźni, podobnie jak kobiety, mają poczucie, że wygląd stanowi istotny zasób ich kapitału ludzkiego i należy o niego dbać. Przy czym, jak już 
zauważono, w grupie kobiet tylko jedna $\mathrm{z}$ respondentek w średnim wieku wspomniała o związku wyglądu i zdrowia.

To, co charakterystyczne dla definicji zdrowia tworzonych na użytek badania przez młodych mężczyzn, co pojawiło się również w wypowiedziach ich rówieśniczek, to określanie zdrowia poprzez dbanie o nie, kojarzenie go ze zdrowym stylem życia, odwoływanie się do indywidualnej odpowiedzialności za własne zdrowie. Młodzi badani obu płci zauważali również, że mianem zdrowej osoby można określić także człowieka cierpiącego na jakieś schorzenie, ale umiejącego z nim żyć, radzącego sobie ze zdrowotnymi ograniczeniami: „(Być zdrowym to - przyp. aut.) nie mieć jakichś poważnych chorób, a nawet jeżeli ludzie mają, to potrafią z tym żyć, czują się młodo, aktywni się czują, nie wykluczają się z wielu obszarów życia codziennego" (MM_10_31). Znajduje tu wyraz przeświadczenie młodych, że to w dużej mierze od człowieka zależy, jak się czuje i jak żyje, czy pozwala na to, by problemy zdrowotne go w jakiś sposób ograniczały.

Młodzi mężczyźni częściej niż starsi respondenci definiowali zdrowie poprzez sprawność funkcjonalną, normalne codzienne funkcjonowanie, związane z możliwością wykonywania różnych czynności bez ograniczeń, pełnienia ról rodzinnych i zawodowych: „Codziennie funkcjonować normalnie, być dostępny dla rodziny” (MM_13_32); „Bycie zdrowym [...], to można wtedy wszystko. To znaczy pracować, nie wiem, biegać, nie wiem, skakać, wszystko" (MM_9_30). Zwraca tu uwagę fakt podkreślenia aktywności mężczyzny nie tylko w sferze publicznej, związanej z pracą zawodową, ale także w sferze prywatnej, w rolach rodzinnych. Aspekt ten pojawił się jedynie w wypowiedziach młodych badanych, co może być wynikiem zmian zachodzących we współczesnych rodzinach, dotyczących m.in. zmiany układu ról płciowych. Przejawia się to w tzw. „nowym”, „aktywnym” ojcostwie (Dzwonkowska-Godula 2015; Grygiel 2010; Sikorska 2009). Młodzi mężczyźni są bardziej zaangażowani w życie rodzinne niż przedstawiciele wcześniejszych pokoleń.

Charakterystyczne dla młodych rozmówców było także traktowanie sprawności i kondycji fizycznej oraz możliwości uprawiania sportu jako kryteriów definicyjnych zdrowia. To oni wskazywali na konkretne „mierniki” tak określanego zdrowia:

Że jak chcę podbiec do autobusu, to mogę podbiec, że jak chcę coś podnieść, to mogę to podnieść, jak chcę wstać, to mogę wstać (MM_6_27). Bycie zdrowym oznacza brak barier do wykonania jakiejś czynności, którą sobie wymyślisz tak? Chcesz wykonać przewrót w przód, jesteś w stanie go zrobić, ok fajnie, to znaczy nie jest jeszcze z tobą tak źle, tak? (MM_7_28). 
$\mathrm{W}$ ich przekonaniu sprawny organizm i dobra kondycja fizyczna wzmacniają odporność, ograniczają ryzyko zachorowań na różnego rodzaju infekcje. Starsi uczestnicy badania (w średnim wieku i starzy) również wspominali o „byciu wysportowanym” czy aktywności sportowej, ale rzadziej i nie wymieniając szczegółowo form ruchowej aktywności.

Respondenci w średnim wieku definiowali zdrowie, przede wszystkim odwołując się do kondycji psychicznej. A zatem w ich przekonaniu zdrowy człowiek cechuje się witalnością, energią do działania i pracy, zadowoleniem z życia, optymizmem:

Zdrowie to pewnego rodzaju taka witalność. Taki zespół czynników, który powoduje, że wszystko jest we mnie w porządku [...], po prostu chce mi się (MSR_1_38). Jeśli nie mam problemu, jeśli dobrze wstaję, [...] jak otwieram oczy rano, to się budzę z uśmiechem, [...] uwielbiam wstawać rano w poniedziałek i iść do pracy. [...] takie budzenie rano jest takim fajnym osobistym cudem, że hurra. I to otworzenie oczu to jest włączenie silnika. Takiego do życia (MSR_12_58). Oprócz tych obiektywnych wskaźników to zdrowie to jest to, że jestem zadowolony z życia, z całości. Jestem optymistą, śmiało patrzę w przyszłość (MSR_3_40).

Oni także stosunkowo najczęściej w grupie objętych badaniem mężczyzn określali zdrowie, odnosząc się do subiektywnego kryterium: dobrego samopoczucia. Z drugiej strony, kluczowe było dla nich także „kryterium medyczne” (Puchalski 1997: 106), przy czym bycie zdrowym definiowali nie przez dobre wyniki badań lekarskich, ale poprzez brak konieczności chodzenia do lekarza, brania lekarstw oraz korzystania ze zwolnień chorobowych. A zatem według uczestników badania w średnim wieku zdrowy człowiek to człowiek, który dobrze się czuje, jest w dobrej kondycji psychicznej oraz nie musi chodzić do lekarza i leczyć się. Można w tej definicji odnaleźć odniesienia do patriarchalnej koncepcji męskości, w świetle której mężczyzna nie choruje, nie ma zatem potrzeby korzystania z medycyny profesjonalnej, jakiekolwiek problemy zdrowotne i dolegliwości, szczególnie natury psychicznej mu „nie przystoją", są bowiem traktowane jako przejaw słabości.

Uczestniczący w badaniu mężczyźni z pozostałych kategorii wiekowych również odnosili się do psychiki w swoich definicjach zdrowia, utożsamiając ją m.in. ze wspominanym pozytywnym nastawieniem, zadowoleniem z życia i z siebie. Jedynie młodzi mężczyźni rozumieli zdrowie psychiczne także jako brak chorób psychicznych („bycie wariatem”, depresja), co wiąże się z zaobserwowaną także u ich rówieśniczek większą świadomością zdrowotną młodych ludzi dotyczącą psychiki jednostki, jej znaczenia dla ogólnie rozumianego zdrowia oraz dolegliwości i chorób psychicznych. Starzy respondenci z kolei jako jedyni wśród objętych 
badaniem mężczyzn odnosili zdrowie psychiczne do sprawnego umysłu, np. dobrej pamięci, co z kolei wynika z obserwowanego przez nich pogarszania wraz z wiekiem zdrowia w tym wymiarze.

Ponadto tym, co wyróżniało starych rozmówców, było uwzględnianie przez nich w definicjach zdrowia ekonomicznego aspektu bycia zdrowym. Wskazywali oni nie tylko na możliwość pracy, a więc zarabiania pieniędzy przez zdrowego człowieka, ale także brak kosztów związanych z leczeniem: „Jak zaczyna już coś dolegać, zaczyna się już coś dziać to znaczy, że nie jestem zdrowy, a co za tym idzie trzeba iść do lekarza, trzeba ponieść odpowiednie koszty, tzn. leki, żeby znowu wrócić do jakiejś przyzwoitej normy" (MST_11_71). Tylko w tej grupie badanych wspomniano także o sprawności seksualnej jako wskaźniku zdrowia. Nie mówili o tym ani młodzi ani respondenci w średnim wieku, nie chcąc prawdopodobnie w żadnym razie podawać $\mathrm{w}$ wątpliwość męskiej potencji, świadczącej o byciu „prawdziwym” mężczyzną. Wypowiadający się na ten temat respondent z najstarszej kategorii wiekowej zaznaczał, że jego "już to tak bardzo nie interesuje, bo w moim wieku to już [...] nie ten" (MST_13_77). Jednak dał wyraz przekonaniu, że mężczyzna musi się także „sprawdzać w łóżku”.

Wreszcie starzy mężczyźni uczestniczący w badaniu, definiując zdrowie, mówili ogólnie o dolegliwościach („,coś dolega”), rzadziej o chorobach jako wyznaczniku bycia niezdrowym. Przypomnijmy, że ich rówieśniczki wymieniały konkretne schorzenia świadczące o braku zdrowia. Te bardziej „ogólnikowe” i lakoniczne wypowiedzi starych respondentów mogą świadczyć o ich gorszej w porównaniu z kobietami w ich wieku wiedzy na temat zdrowia i różnego rodzaju chorób, także tych związanych $\mathrm{z}$ wiekiem lub też o braku przywiązywania wagi do problemów zdrowotnych, zgodnie z zasadą "mężczyźni nie chorują?. Ponadto, co jest charakterystyczne dla starych uczestników badania obu płci, określanie zdrowego człowieka jako takiego, „któremu nic nie dolega” odnosiło się przede wszystkim do zdrowia fizycznego: sprawnego funkcjonowania organizmu, nieodczuwania bólu, braku chorób różnych narządów.

Reasumując, analiza definicji zdrowia podawanych przez kobiety i mężczyzn w trzech kategoriach wiekowych pozwala zauważyć wpływ socjalizacji płciowej i kulturowych koncepcji płci na sposób określania, co to znaczy być zdrowym. Zgodnie z kulturowymi ideałami kobiecości i męskości zdrowie jest przedmiotem troski kobiet, którym daje się większe przyzwolenie na odczuwanie, a przede wszystkim przyznawanie się do różnego rodzaju dolegliwości i problemów zdrowotnych i u których rozwija się większą świadomość zdrowotną. Wypowiadający się przedstawiciele płci męskiej dawali wyraz przekonaniu, że zdrowy mężczyzna to ten, który jest sprawny fizycznie i psychicznie, zdolny do pracy, nie korzysta z opieki lekarskiej, dobrze się czuje. 
Uwzględniając wiek badanych, można zauważyć, że młodzi są do siebie bardziej podobni $\mathrm{w}$ rozumieniu zdrowia niż kobiety i mężczyźni w starszych kategoriach wiekowych. Młodych łączyło m.in. definiowanie zdrowia poprzez odwołanie do zdrowego stylu życia, większe przywiązywanie wagi do zdrowia psychicznego i większa świadomość zdrowotna w tym zakresie. Zaobserwowane różnice definicji zdrowia formułowanych przez osoby $\mathrm{w}$ różnym wieku mogą wynikać $\mathrm{z}$ jednej strony z kulturowych koncepcji wieku: młodości, wieku średniego i starości, tworzonych na podstawie charakterystyk wieku biologicznego. A zatem np. różnice w ujmowaniu sprawności fizycznej jako kryterium definicyjnego zdrowia są konsekwencją różnic w fizycznych możliwościach młodego i starego organizmu. Z drugiej strony możemy tu mieć do czynienia $\mathrm{z}$ różnicami generacyjnymi, wynikającymi z socjalizacji kolejnych pokoleń w odmiennych warunkach społeczno-kulturowych. Na przykład częstsze wskazywanie przez młodych na znaczenie zdrowia psychicznego może być efektem ich większej wiedzy na temat problemów psychicznych dokuczających współczesnym ludziom, w wyniku nagłaśniania przez media kwestii związanych z stresem, problemami z układem nerwowym, depresją i innymi chorobami psychicznymi. Podobnie utożsamianie zdrowia $\mathrm{z}$ dbaniem o zdrowie przez młodych ludzi wynikać może z faktu, że dorastali oni w kulturze, w której propaguje się ideologię healthismu i modę na zdrowy styl życia. Wydaje się także, co potwierdzają rozważania dotyczące innych aspektów postaw wobec zdrowia, prezentowane w kolejnych rozdziałach, że dostrzeżone różnice w sposobie myślenia o zdrowiu wypowiadających się kobiet i mężczyzn ze starszych grup pokoleniowych, mogą wynikać z patriarchalnego modelu ich socjalizacji, opartego na odmiennych oczekiwaniach stawianych przedstawicielom obu płci. Podobieństwo przekonań w młodym pokoleniu może być przejawem „nowoczesnego" sposobu definiowania kobiecości i męskości, prowadzącego do depolaryzacji płci i androgynizacji (Arcimowicz 2003; Dzwonkowska-Godula 2015). Przykładem mogą tu być wypowiedzi młodych mężczyzn, niemających problemu $\mathrm{z}$ mówieniem o psychicznych aspektach zdrowia czy też zwracających uwagę na związek zdrowia $\mathrm{z}$ wyglądem, co w świetle patriarchalnej koncepcji płci można by traktować jako „niemęskie”. Można zatem uznać za zasadne postawienie hipotezy, że płeć słabo różnicuje postawy wobec zdrowia młodych ludzi, co zaobserwowano tu $\mathrm{w}$ odniesieniu do jednego $\mathrm{z}$ aspektów komponentu poznawczego tej postawy: sposobu rozumienia tego zasobu. Przekonania osób w średnim wieku i starych są zróżnicowane ze względu na płeć, co wynika $\mathrm{z}$ realizowania przez nie $\mathrm{w}$ większym zakresie patriarchalnych wzorów kobiecości i męskości. 


\subsubsection{Czynniki wpływające na stan zdrowia wedtug kobiet i mężczyzn w różnym wieku (Krystyna Dzwonkowska-Godula)}

Komponent poznawczy postaw wobec zdrowia „obejmuje przekonania i wiedzę o obiekcie postawy, jego naturze i własnościach” (Nowak 1973: 43). W wywiadach swobodnych przeprowadzanych z kobietami i mężczyznami w różnym wieku znalazło się pytanie o czynniki warunkujące stan zdrowia. Badani określali, od czego, ich zdaniem, zależy zdrowie. Przekonania na ten temat stanowią istotny element świadomości zdrowotnej i leżą u podstaw aktywności/bierności w zakresie dbałości o ten zasób kapitału ludzkiego. Jeżeli bowiem jednostki mają poczucie, że ich zdrowie zależy od nich samych, od ich stylu życia, podejmowanych działań, można spodziewać się, że będą one czuły się odpowiedzialne za stan własnego zdrowia i będą „brały sprawy we własne ręce”. Osoby przekonane, że stan zdrowia nie zależy od nich, ale jest „dany”, „zastany” oraz uwarunkowany zewnętrznymi, niezależnymi od nich czynnikami, mogą okazywać się bierniejsze w zakresie działań prozdrowotnych.

W naukowym dyskursie na temat czynników kształtujących zdrowie dominuje (od końca lat siedemdziesiątych ubiegłego wieku) koncepcja „pól zdrowia” Marca Lalonde’a, według której największy wpływ na stan zdrowia człowieka ma jego styl życia (50-60\%), następnie czynniki środowiskowe (przy czym ma się tu na względzie wpływ środowiska fizycznego na poziomie $5-10 \%$ oraz otoczenia społecznego na poziomie $25 \%$ ), czynniki genetyczne (biologiczne) (5-15\%) oraz medycyna, opieka zdrowotna (10-20\%) (Ostrowska 1998: 149; Piątkowski 2002: 23). Mówi się o „społecznej naturze zdrowia”, odchodząc od medycznej perspektywy postrzegania zdrowia i koncentrując się na społecznych determinantach stanu i ochrony zdrowia (Słońska 2010: 65). Wśród nich zwraca się uwagę na znaczenie „sfery wiedzy, poglądów, opinii i zachowań związanych ze zdrowiem”, „laickich koncepcji zdrowia, laickich poglądów na temat dbania o zdrowie i jego ochrony oraz zachowań zdrowotnych" (Słońska 2010: 66).

Czynniki, od których zależy zdrowie człowieka, wskazywane przez uczestników badania - kobiety i mężczyzn w różnym wieku - odpowiadały w większości wymienianym wyżej polom. Przedstawiciele obu płci i wszystkich kategorii wieku dostrzegali znaczenie uwarunkowań zdrowia zarówno zależnych, jak i niezależnych od człowieka, takich jak: styl życia (w tym sposób odżywiania się, aktywność fizyczna, stosowanie używek), dbanie o zdrowie, obciążenia genetyczne oraz zdrowie psychiczne (co oznacza, że zdrowie jest utożsamiane w pierwszej kolejności ze zdrowiem fizycznym, traktowanym jako zależne od sfery psychicznej, duchowej). Inne wymieniane (już nie we wszystkich grupach badanych) 
czynniki wpływające na stan zdrowia to środowisko życia (w sensie fizycznym: miejsce zamieszkania czy stan środowiska naturalnego oraz $\mathrm{w}$ sensie społecznym: rodzina, relacje z innymi ludźmi), narażenie na stres i umiejętność radzenia sobie z nim, czynniki ekonomiczne, praca zawodowa, służba zdrowia, wypadki losowe, przebyte choroby oraz wiek.

Analiza wypowiedzi badanych pokazuje, że płeć i upłciowiony wiek różnicują przekonania na temat uwarunkowań zasobów zdrowotnych. Przyjrzyjmy się najpierw poglądom kobiet i mężczyzn. Rozmówczynie nieco częściej od przedstawicieli płci przeciwnej wskazywały na znaczenie genów dla stanu zdrowia jednostki. Zaznaczały, że niektóre schorzenia, predyspozycje do określonych chorób, czy odporność na infekcje i długowieczność, są dziedziczone i człowiek nie ma na to wpływu. Niektóre z nich odwoływały się do własnych doświadczeń: „No, niezaprzeczalnie geny. Tak, że pochodzę ze zdrowej rodziny. W mojej rodzinie nie ma jakichś problemów zdrowotnych" (KM_15_35); "Jeśli chodzi o moje nogi, które bolą w nocy, to na pewno mam po ojcu" (KST_1_64). Kobiety wymieniały uwarunkowane genetycznie ( $w$ ich przekonaniu) konkretne choroby czy dysfunkcje organizmu (choroby przewlekłe jak cukrzyca, choroby nowotworowe), wykazując się wiedzą medyczną, a także poczuciem odpowiedzialności za własne zdrowie. Uczestniczki podkreślały bowiem, że świadomość takich genetycznych obciążeń pozwala na przeciwdziałanie pogorszeniu stanu zdrowia, podjęcie odpowiednich środków zaradczych (np. stosowanie określonej diety, czy regularna kontrola lekarska). Wyrażały przekonanie, że wiedza o ewentualnym ryzyku zachorowania zobowiązuje je do profilaktyki. Pojawily się jednak także uwagi, że część chorób trudno wykryć we wczesnym stadium mimo badań profilaktycznych. Ta większa świadomość zdrowotna kobiet i troska o zdrowie $\mathrm{w}$ porównaniu $\mathrm{z}$ mężczyznami (przejawiająca się $\mathrm{w}$ różnych aspektach postawy wobec zdrowia, zarówno w komponencie poznawczym, jak i behawioralnym, co pokazują kolejne rozdziały niniejszego opracowania) wynika z procesu socjalizacji płciowej oraz roli opiekunki i domowego lekarza pełnionych przez kobiety w rodzinie.

Mężczyźni uczestniczący w badaniu, wskazujący na genetyczne wyposażenie jednostki jako czynnik wpływający na zdrowie, zdawali się bagatelizować jego wpływ (młodzi respondenci) albo podkreślali bezradność człowieka i nieuchronność choroby mimo podejmowanych działań, usprawiedliwiając tym samym bierność w dbaniu o zdrowie (badani w średnim wieku). W przypadku pierwszej grupy badanych ten lekceważący stosunek do biologicznych uwarunkowań stanu zdrowia mógł wynikać $\mathrm{z}$ tego, że młodzi respondenci nie zaobserwowali u siebie wynikających z nich dolegliwości bądź nie były to poważne schorzenia, utrudniające im życie: „Nadciśnienie u nas jest rodzinne, mój dziadek 
ma, tata ma i ja mam, to jest genetyczne, ale bez przesady" (MM_2_22). Wyrażali oni przekonanie, że to jednak przede wszystkim ich zachowania determinują stan ich zdrowia. W przypadku drugiej grupy uczestników badania podawano przykłady przegranej w walce $\mathrm{z}$ chorobami uwarunkowanymi genetycznie, dochodząc niejako do wniosku, że nie warto się starać, bądź że nie należy spodziewać się zbyt wiele po podejmowanych prozdrowotnych działaniach: „[...] Bo jak ktoś ma choroby jakieś dziedziczne w rodzinie, to musi uważać, a czasami, to, że uważa, to nic nie pomoże, bo jak ma jakieś takie tendencje, to nie ma zmiłuj” (MSR_13_60).

Tym, co odróżniało wypowiedzi kobiet od wypowiedzi mężczyzn, było także częstsze wymienianie przez uczestniczki badania miejsca zamieszkania i środowiska życia jako czynnika wpływającego na zdrowie. Respondentki mówiły o negatywnym wpływie życia w mieście, zanieczyszczonym powietrzu, zagrożeniach związanych $\mathrm{z}$ odchodzeniem od natury i wszechobecną „chemią”, elektrowniami atomowymi: „Na pewno środowisko, środowisko, to na pewno nie wpływa korzystnie. Może też to, gdzie mieszkamy czy na przykład w mieście, czy poza miastem” (KM_7_28); „[...] to może to, ogólny stan cywilizacyjny kraju, o, że to może mieć wpływ [...]. No te, te elektrownie atomowe i te różne takie, i ta chemia” (KST_14_86). Ich obserwacje potwierdzają wrażliwość kobiet na kwestie ekologiczne, przywiązywanie przez nie wagi do ochrony środowiska, wskazywane przez Geerta Hofstede, który traktował taką postawę jako jeden ze wskaźników kobiecego wymiaru kultury (Hofstede 2000; Malinowska 2003: 97).

Kobiety, wypowiadając się na temat czynników warunkujących stan zdrowia, nieco częściej niż mężczyźni mówiły także o znaczeniu zdrowia psychicznego dla ogólnej kondycji zdrowotnej człowieka. Wymienianie zdrowia psychicznego wśród czynników wpływających na stan zdrowia przez badanych (także mężczyzn) wskazuje, że zdrowie jest przez nich kojarzone w pierwszej kolejności z fizycznym dobrostanem, na który wpływa m.in. psychika. Jak zauważono we wcześniejszym podrozdziale poświęconym analizie sposobu rozumienia zdrowia przez badanych, to zaobserwowane większe przywiązywanie przez kobiety wagi do zdrowia psychicznego w porównaniu z mężczyznami może wynikać z ich subiektywnie ocenianej gorszej kondycji psychicznej oraz ich większej podatności na takie choroby psychiczne jak depresja czy zaburzenia lękowe (CBOS 2012a: 93, 96; Tobiasz-Adamczyk 2000: 124; Ostrowska 2006: 120; Frąckowiak-Sochańska 2011: 396). Odpowiadając na pytanie, od czego zależy zdrowie, respondentki z jednej strony wskazywały, że stan psychiki i nastawienie jednostki mają wpływ na zdrowie fizyczne i funkcjonowanie organizmu (np. wrzody żołądka spowodowane podatnością na stres), 
a także radzenie sobie $\mathrm{z}$ chorobą (podawano przykłady hipochondrii i wmawiania sobie chorób, mogące działać jak samospełniające się proroctwo):

Sądzę, że spokój psychiczny ma największy wpływ (KM_8_29). To na pewno jest naukowo udowodnione, że te, kiedy się uśmiechamy, to się nam wydzielają jakieś hormony, które podtrzymują nasz, nasze funkcjonowanie też, naszego organizmu, tak. Czyli to że jesteśmy radośni, śmiejemy się, jesteśmy optymistyczni, to wpływa też na stan zdrowia somatyczny, tak (KSR_5_47).

$\mathrm{Z}$ drugiej strony badane wypowiadały się na temat uwarunkowań zdrowia psychicznego, wymieniając relacje z ludźmi, ułożone życie rodzinne i zawodowe, dające poczucie komfortu psychicznego i szczęścia, dobrze wpływające na zdrowie: „[...] ogólnie relacje z ludźmi, praca, stan umysłu dookoła, to czy jesteśmy szczęśliwi, to wpływa na psychikę" (KM_10_30); „Poza tym dom, rodzina, ciepło rodzinne, dzieci udane to wszystko to wpływa na moje zdrowie fizyczne i ja to wszystko mam" (KST_5_67). W przytaczanych stwierdzeniach zwraca uwage podkreślanie przez kobiety znaczenia rodziny w ich życiu i jej wpływu na ich psychiczną kondycję. Z części wypowiedzi wynika, że choroby bliskich osób, szczególnie dzieci, stanowią dla respondentek psychiczne obciążenie, co wynika z opiekuńczej roli kobiety oraz kształtowanego w procesie socjalizacji poczucia odpowiedzialności za zdrowie członków rodziny i kobiecej empatii. Ponadto konieczność sprawnego godzenia obowiązków rodzinnych i zawodowych przez kobietę była wskazywana przez badane jako czynnik motywujący je do dbania o zdrowie: „Może to zabrzmi śmiesznie. W tym momencie mój organizm wie, że sobie nie mogę pozwolić na chorowanie, bo przy ilości rzeczy, które się dzieją w moim życiu, przy dwójce dzieci, pracy i natężeniu tego, co się dzieje w ciągu dnia, jakbym miała się rozchorować, to by było mi ciężko" (KSR_1_38). Przytoczona wypowiedź była typowa dla respondentek, stwierdzających w wywiadach, że „one nie mogą być chore, bo kto by się zajął domem i dziećmi". Odwoływały się one do przypisanych kobietom ról opiekunki domowego ogniska, żony i matki. Kobieta zatem, jeśli dba o własne zdrowie, to nie dla siebie, a dla innych, by móc odgrywać swoje społeczne role.

Nie tylko jednak kobiety mówiły o znaczeniu relacji społecznych i życia rodzinnego dla zdrowia człowieka, chociaż „orientacja interpersonalna" jest powszechnie traktowana jako kobieca właściwość (Wiliams, Best 1982, za: Miluska 1996: 75). Respondenci - mężczyźni także podkreślali, że jakość życia prywatnego, rodzinnego wpływa na samopoczucie człowieka, a tym samym jego stan zdrowia: 
Jeśli w swojej aktualnej rodzinie jest toksycznie, masz tam kiepskie relacje, no to też raczej nie wpływa (dobrze - przyp. aut.) na twoje zdrowie, tak (MSR_3_40). (Czynniki - przyp. aut.) międzyludzkie, to znaczy, żeby był głównie spokój w domu. No spokój, nie denerwować się, nie kłócić, nie czepiać się rzeczy błahych, a robić z tego wielką awanturę. No to ma bardzo duży wpływ [...]. Tak, sytuacja rodzinna [...]" (MST_13_77).

Przy czym, co można zauważyć w przytoczonych wyżej wypowiedziach, badane wskazywały raczej na pozytywny wpływ rodziny i ułożonego życia prywatnego, podczas gdy mężczyźni, przede wszystkim ci w średnim wieku i starzy, mający za sobą więcej doświadczeń niż młodzi, mówili o negatywnym wpływie na zdrowie nie najlepszych relacji w rodzinie i konfliktów z bliskimi.

Uczestniczący w badaniu mężczyźni częściej niż respondentki wymieniali pracę zawodową jako czynnik wpływający na stan zdrowia człowieka. Niektórzy wskazywali na pozytywną rolę samego faktu bycia aktywnym zawodowo, inni podkreślali znaczenie rodzaju i warunków wykonywanej pracy, w tym atmosfery i relacji międzyludzkich:

Praca, jedzenie, sposób życia i twoje zainteresowania jako hobby (mają wpływ na zdrowie - przyp. aut.) (MM_5_25). Na pewno praca, którą miałem, miała duży wpływ na stan zdrowia, bo pracowałem w warunkach szkodliwych, także chemikalia na pewno dały dużo negatywnego (MST_11_71). W pracy też były różne (stresujące - przyp. aut.) historie, bo różne donoszenia, skarżenia, niesłuszne jakieś tam donosy. Różnie to bywało (MST_13_77).

Uwzględnianie przez mężczyzn pracy zawodowej wśród uwarunkowań zdrowia świadczy o znaczeniu aktywności w sferze publicznej w ich życiu (jak wskazuje pierwsza z przytoczonych wyżej wypowiedzi, według niektórych ma ona pierwszoplanowe znaczenie dla kondycji zdrowotnej), co odpowiada patriarchalnemu modelowi męskości. Praca niektórych mężczyzn miała charakter fizyczny, wymagała siły i sprawności, co respondenci postrzegali jako atut, bo, przypomnijmy, że kryterium definicyjnym zdrowia dla wielu z nich była właśnie dobra kondycja fizyczna, którą udawało im się osiągać, po prostu wykonując swoje zawodowe obowiązki. W przypadku wypowiedzi kobiet, jeśli pojawiały się w nich wzmianki o pracy zawodowej, to dotyczyły one raczej jej negatywnego wpływu na zdrowie człowieka (a dokładnie samych rozmówczyń, bo odwoływały się one do swoich doświadczeń). Badane mówiły o pracy jako źródle stresów, niekorzystnym siedzącym trybie życia w związku z pracą przy komputerze czy zagrożeniu częstymi infekcjami towarzyszącym pracy z dziećmi. Zdaniem Beaty Tobiasz-Adamczyk: 
Relację pomiędzy karierami zawodowymi kobiet a ich stanem zdrowia (kondycją fizyczną, stresem psychicznym), można rozpatrywać w odniesieniu do narażenia na uwarunkowania środowiska pracy, przede wszystkim napięcia towarzyszącego wykonywanej pracy, szczególnie z racji wysokich wymagań i równocześnie niskiej autonomii (Tobiasz-Adamczyk 2009: 444).

Autorka wskazuje, że źródłem stresu dla kobiet może być także wielość pełnionych przez nie ról, często pozostających ze sobą w konflikcie, bo opartych na sprzecznych oczekiwaniach, wymagających „czasu, energii i psychologicznego zaangażowania” (Tobiasz-Adamczyk 20o9: 444).

W'́ród wymienianych przez wypowiadających się mężczyzn czynników wpływających na zdrowie pojawiły się także przyczyny ekonomiczne, związane bezpośrednio z pozycją na rynku pracy. Mówili o nich respondenci z każdej grupy wiekowej, w przypadku kobiet - tylko najstarsze respondentki. Przy czym wskazywały one przede wszystkim na wpływ posiadanych zasobów finansowych na dietę - „odpowiednie” czy „lepsze” odżywianie (KST_16_89; KST_9_71).

Mężczyźni natomiast podkreślali konieczność „inwestowania w zdrowie”, co wiąże się z określonymi kosztami opłacenia „specjalistów, lekarzy, rehabilitantów, SPA, basenów i różnych dziwnych rzeczy" (MM_7_28), przyspieszenia wizyty lekarskiej, wykonania badań profilaktycznych od ręki, bez czekania w kolejkach (MSR_8_53). Ich wypowiedzi świadczą o traktowaniu przez nich zdrowia jako kapitału, zasobu, o który trzeba dbać, co wymaga określonych nakładów finansowych. Wskazywali oni tym samym na istnienie nierówności społecznych w sferze zdrowia, wynikających z różnic w statusie ekonomicznym:

No i ten stan posiadania, możemy tak gadać, że nie, ale na pewno tak? No jeżeli masz ten zasób portfela trochę większy, to jesteś w stanie więcej dać sobie, tak? (MM_7_28). Niewątpliwie stan zasobów finansowych też ma wpływ na nasze zdrowie, prawda? Wtedy możemy sobie pozwolić na więcej, żeby to zdrowie zabezpieczyć w jakiś sposób (MSR_8_53).

Powyższe wypowiedzi korespondują z koncepcją „kapitału zdrowia” zaproponowaną przez Joannę M. Zabielską (Zabielska 2010: 343). Jednym z jego wymiarów jest „taka część dochodów, która wydatkowana jest na podwyższanie ogólnego stanu zdrowia (np. nieobowiązkowe, a płatne szczepienia, badania okresowe)" (Zabielska 2010: 343). Jak pokazują wyniki badania, w grupie respondentów to mężczyźni byli bardziej skłonni do „wyceniania” dbałości o zdrowie. Może to być z jednej strony przejaw ich „męskiej” racjonalności i instrumentalizmu. Z drugiej strony uzależnianie stanu zdrowia od statusu majątkowego pozwala części z nich „zrzucić winę” za złą kondycję psychofizyczną na czynniki zewnętrzne 
- „nie mam pieniędzy, to nie chodzę do lekarza, nie leczę się, nie stać mnie, by o siebie zadbać", itp.

Charakterystyczne dla respondentów było także częstsze w porównaniu z uczestniczkami badania wymienianie przez nich stosowania używek - papierosów i alkoholu - wśród czynników wpływających na zdrowie. Wynika to prawdopodobnie $\mathrm{z}$ faktu, że, jak pokazują badania społeczne, mężczyźni dominują w zbiorowości palaczy oraz osób spożywających wysokoprocentowe alkohole (Malinowska, Dzwonkowska-Godula, Garncarek 2012: 124-125). Jest to uwarunkowane kulturowo i wiąże się z mniejszym społecznym przyzwoleniem dla kobiet spożywających alkohol i palących papierosy (używki są uznawane za „niekobiece”, negatywnie wpływające na urodę), podczas gdy męskość od wieków kojarzona jest $\mathrm{z}$ używaniem tego typu substancji psychoaktywnych (Malinowska, Dzwonkowska-Godula, Garncarek 2012: 125).

Uwzględniając $\mathrm{w}$ analizie zebranego materiału upłciowiony wiek, tj. kulturowe koncepcje kobiecości i męskości zróżnicowane w odniesieniu do ludzi będących w różnych fazach życia, dostrzegamy jego różnicujący wpływ na przekonania respondentów dotyczące czynników wpływających na zdrowie. W wyniku procesu socjalizacji i odmiennych społecznych oczekiwań kobiety i mężczyźni w różnym wieku zwracają uwagę na inne aspekty determinujące zdrowie człowieka. Przyjrzyjmy się najpierw zróżnicowaniu przekonań w zbiorowości badanych kobiet, by następnie porównać poglądy dotyczące uwarunkowań zdrowia wyrażane przez uczestniczących w badaniu mężczyzn reprezentujących różne kategorie wiekowe.

Młode respondentki stosunkowo częściej niż starsze badane wyrażały przekonanie o indywidualnej odpowiedzialności człowieka za własną psychofizyczną kondycję. To one przede wszystkim mówiły o znaczeniu stylu życia dla zdrowia, wskazując różne jego elementy:

Jeśli bym cały czas siedziała w domu i po prostu opychała się fast foodami, to nie sądzę, żeby to było dla mnie zdrowe [...]. No na pewno jak ktoś pije alkohol tak często, no to też biedna wątroba też chyba nie da rady. No i jak się pali, no i jeśli ktoś nadużywa narkotyków, jeśli bierze takie inwazyjne, już nie mówię o jakiejś marihuanie, która nic nie robi w sumie, jakieś heroina itd. jak się patrzy na zdjęcia ludzi, to widać, co to z nimi robi. Też jak się człowiek prowadzi, jeśli się sypia z kim się popadnie, no to też można załapać, co się nie chce załapać. Więc sądzę, że takich rzeczy należy unikać (KM_3_24).

Młode rozmówczynie wyróżniały się przywiązywaniem wagi do sposobu odżywiania jako czynnika wpływającego na zdrowie: „Odżywiamy się niezdrowo, to jesteśmy niezdrowi” (KM_9_30). W ich wypowiedziach pojawiały się uwagi, że ,jesteśmy tym, co jemy” oraz przykłady 
stosowanych przez nie diet np. wegetarianizmu czy też określonych zasad żywienia (dotyczących wielkości oraz składu posiłków oraz częstotliwości ich spożywania). Badane zwracały uwagę, że niewłaściwa dieta wpływa niekorzystnie na wygląd, powoduje nadwagę i może prowadzić do różnych problemów zdrowotnych (podwyższenie poziomu cholesterolu, cukrzyca, ale także problemy z płodnością, o czym wspomniała jedna $\mathrm{z}$ respondentek). Biorąc pod uwagę wyniki badania dotyczące dbałości o wygląd, w których młode kobiety podkreślały znaczenie sposobu odżywiania się dla atrakcyjności fizycznej, można stwierdzić, że to priorytetowe traktowanie diety powodowane jest nie tyle zdrowotnymi względami, co chęcią bycia atrakcyjnym, tj. spełnienia ideału pięknej, czyli szczupłej kobiety. Ta „tyrania szczupłości” (Bartky2007, Wolf 2014), której poddawane są przede wszystkim młode kobiety, prowadzi do częstszego odchudzania się przez przedstawicielki „płci pięknej”, także przy pomocy różnego rodzaju środków farmakologicznych (CBOS 2009a).

Młode rozmówczynie stosunkowo częściej niż badane ze starszych kategorii wiekowych mówiły o wpływie używek na zdrowie człowieka. Może to być wynikiem częstszego ich stosowania przez przedstawicieli tego pokolenia $\mathrm{w}$ porównaniu ze starszymi osobami ${ }^{5}$, ale także zmiany modelu kobiecości, przejawiającej się m.in. w zwiększającym się społecznym przyzwoleniu dla palących i pijących alkohol kobiet w miejscach publicznych. Przedstawicielki młodego pokolenia jako jedyne w zbiorowości badanych kobiet zwracały także uwagę na konieczność dbania o zdrowie psychiczne. Wśród czynników warunkujących psychofizyczną kondycję człowieka wymieniały działania, mające na celu wyciszenie, rozwijanie sfery duchowej np. poprzez medytację: „Jakaś medytacja, którą zaczęłam się interesować w ostatnim roku, [...] czy jakaś taka potrzeba takiego wyciszenia się i takie zadbanie nie tylko o taką strefę zewnętrzną, estetyczną, ale też i duchową" (KM_15_35).

Młode badane w swoich wypowiedziach dawały wyraz przekonaniu, że to sama jednostka jest w stanie przyczynić się do zachowania, czy polepszenia swojego stanu zdrowia, bądź jego pogorszenia czy utraty. W niektórych przypadkach to poczucie odpowiedzialności za własne zdrowie przybierało skrajne formy. Wśród młodych kobiet uczestniczących w badaniu znalazły się osoby przekonane o tym, że właściwie wszystko, co robią, wszystkie dokonywane przez nie wybory i podejmowane działania w każdej sferze życia mają wpływ na ich psychofizyczną kondycję. Ich wypowiedzi świadczą o dużej refleksyjności i świadomości zdrowotnej, a także zainteresowaniu własnym zdrowiem i możliwościami wpływu

5 Dotyczy to przede wszystkim picia alkoholu oraz zażywania narkotyków (CBOS 2010; 2011; 2012d). 
na nie. Jako czynnik rzutujący na zdrowie badane wymieniały, obok stylu życia, dbanie o własną kondycję psychofizyczną, podkreślając konieczność świadomego rozwijania/utrzymywania tego zasobu przez jednostkę. Niektóre z nich wyrażały opinie, odwołując się niekiedy do wiedzy naukowej, że człowiek poprzez swoje działania - odpowiedni styl życia (dietę, aktywność fizyczną), dbanie o zdrowie - może nawet ograniczać ryzyko zachorowania na choroby, którymi jest genetycznie obciążony: „Większość chorób nowotworowych, które są dziedziczone, to też możemy przeciwdziałać. Czytałam ostatnio artykuł, że osoby, które uprawiają sport, mają mniejsze ryzyko zachorowania na nowotwory. Również na te niby genetycznie dziedziczone" (KM_9_30). Ich wypowiedzi świadczą o przenikaniu wiedzy naukowej do wiedzy potocznej o zdrowiu i jej wykorzystywaniu przez laików do analizy własnych problemów, sytuacji życiowych oraz podejmowania takich a nie innych działań (Giddens 2001: 32). Przede wszystkim wskazują one jednak, że młode uczestniczki badania szukają informacji na temat zdrowia i możliwości dbania o nie, korzystając ze specjalistycznej wiedzy. Możemy zauważyć tu zjawisko profesjonalizacji postaw wobec zdrowia. Same respondentki zwracały uwage na to, że dbanie o zdrowie wymaga wiedzy, przy czym podkreślały, że powinna ona pochodzić z wiarygodnych źródeł. Ich opinie są z jednej strony wyrazem bezradności wobec wielości często sprzecznych ze sobą głosów na temat zdrowia i efektów prozdrowotnych działań (np. rozmaitych diet), a z drugiej strony wyrazem ostrożności i sceptycyzmu wobec wszechobecnych „ekspertów”:

Bardzo duży wpływ mają media i trzeba ustosunkować się do tego, co jest $\mathrm{w}$ telewizji, Internecie. Podchodzić do tego z dystansem i znajdować wiarygodne źródła wiedzy [...]. Ja staram się unikać Internetu. Jeżeli chcę się czegoś dowiedzieć, to wolę wziąć książkę, czyli takie źródło wiedzy, które wiem, że zostało napisane przez jakiegoś profesora, doktora, magistra i jeszcze musiało przejść przez jakiegoś redaktora i zostać sprawdzone (KM_2_24).

Dla respondentek $\mathrm{w}$ średnim wieku, $\mathrm{w}$ porównaniu $\mathrm{z}$ młodszymi i starszymi badanymi, charakterystyczne było wskazywanie na znaczenie zdrowia psychicznego jako czynnika wpływającego na zdrowie człowieka. Przypomnijmy, że młode uczestniczki badania wspominały o konieczności dbania o ten aspekt funkcjonowania organizmu, podczas gdy przedstawicielki „średniego" pokolenia uznawały samo zdrowie psychiczne za jedno z uwarunkowań kondycji psychofizycznej. Może to wynikać $\mathrm{z}$ fazy życia, w jakiej znalazły się respondentki. Wiek średni jest wskazywany jako czas, w którym człowiek dokonuje bilansu dotychczasowych osiągnięć i uświadamia sobie skończoność życia (Chmura-Rutkowska, Ostrouch 2007: 41). Towarzyszyć mu może „poczucie 
przygnębienia i smutku z powodu utraty takich atrybutów młodości jak: witalność, siła, uroda, sprawność seksualna, wolność czy radość życia” (Chmura-Rutkowska, Ostrouch 2007: 43). W przypadku kobiet znaczenie ma także syndrom „pustego gniazda”, związany z opuszczaniem przez dzieci domu rodzinnego, a także niesprzyjający im (ze względu na płeć i wiek) rynek pracy (Backes 2006, za: Tobiasz-Adamczyk 2009: 442). W swoich wypowiedziach respondentki mówiły o znaczeniu umiejętności radzenia sobie ze stresem $i$,uodporniania się" na różne stresujące wydarzenia życiowe: „w moim zawodzie to są na okrągło te stresy, ale człowiek się na pewne rzeczy uodparnia. [...] znam osoby, które tak, stres jest powodem wielu chorób. Łącznie z psychicznymi. Ludzie sobie nie radzą, no tak, tak. Śmialiśmy się z Amerykanów, że mają tych analityków, a teraz sami do nich zapylamy" (KSR_14_53).

Jak już wspomniano, kobiety mają większą łatwość mówienia o odczuwanych problemach natury duchowej czy psychicznej w porównaniu z mężczyznami. W wypowiedziach badanych w średnim wieku pojawiły się odwołania do takich osobistych, negatywnych doświadczeń: „Mam stres. No wiadomo, że każdy ma. Takie doły psychiczne no wiesz. Czasami się budzę i myślę, że jestem w czarnej dziurze i mi się wyjść nie chce, jakaś depresja, ale jednak mija" (KSR_3_42). Tę kategorię wiekową respondentek łączyło ze starymi uczestniczkami badania podkreślanie znaczenia rodziny jako czynnika wpływającego na zdrowie człowieka, którego w ogóle nie wymieniały młode uczestniczki badania. Ta pokoleniowa różnica we wskazywaniu tego rodzaju uwarunkowań może wynikać z faktu, że część najmłodszych respondentek nie założyła jeszcze własnej rodziny. $Z$ kolei badane ze starszych grup wiekowych doceniały wsparcie ze strony najbliższych, zarówno w związku ze wspominanymi kłopotami natury psychicznej, jak i ze stopniową wraz z wiekiem utratą samodzielności i niezależności. One także doświadczyły negatywnego wpływu tego, co dzieje się w rodzinie (np. choroby dziecka) na własne zdrowie, stąd też wskazywanie przez nie życia prywatnego jako istotnego uwarunkowania kondycji psychofizycznej.

W grupie wypowiadających się kobiet tylko wśród badanych w średnim wieku pojawiły się uwagi dotyczące konieczności ciągłego rozwoju umysłowego, co może być przejawem lęku przed różnego rodzaju słabościami i dysfunkcjami umysłu pojawiającymi się wraz z wiekiem: „No zdecydowanie umysłowa (aktywność ma także wpływ na zdrowie - przyp. aut.), zdecydowanie umysłowa, czyli czytamy, oglądamy tyle, ile wrażeń jesteśmy w stanie skumulować, różnorodnych, czy to $\mathrm{z}$ wystaw, z wycieczek czy ze spotkań z ludźmi, to jest ważne. Czyli nasz intelektualny rozwój, czyli harmonia powinna być [...]" (KSR_11_6o). Powyższą wypowiedź respondentki, będącej u progu metrykalnej starości, można 
także odczytać jako wyraz niezgody na negatywny stereotyp starego człowieka jako biernego, niesprawnego fizycznie i umysłowo, a także na stereotyp starej kobiety mającej zajmować się wnukami, zamkniętej w domu, skupionej przede wszystkim na zaspokajaniu potrzeb najbliższych.

Przedstawicielki starego pokolenia uczestniczące w badaniu wyróżniały się wśród respondentek wskazywaniem wieku jako czynnika warunkującego zdrowie człowieka. Mówiły o „zużywaniu się organizmu”, ogólnym osłabieniu i ograniczeniu sprawności, pojawieniu się dolegliwości i schorzeń związanych z podeszłym wiekiem. Wypowiadając się na temat diety jako czynnika wpływającego na zdrowie, wskazywały głównie na konieczność zmiany nawyków żywieniowych w związku z wiekiem i związanymi z nim zmianami w przemianie materii i problemami zdrowotnymi. Wspominały o konieczności unikania tłustych, ciężkostrawnych potraw, a także słodyczy oraz o umiarze w jedzeniu, ze względu na obciążenie układu pokarmowego, ale i skłonność do nadwagi.

Ze względu na gorszy stan zdrowia (oceniany obiektywnie i subiektywnie) i związane $\mathrm{z}$ wiekiem problemy zdrowotne stare respondentki przywiązywały dużą wagę do medycyny profesjonalnej, wskazując na jej znaczenie dla zdrowia człowieka. Wspominały o badaniach profilaktycznych, systematycznym chodzeniu do lekarza, o konieczności leczenia zdiagnozowanych chorób, zażywaniu leków jako działaniach mających wpływ na zdrowie: „Uważam, że masz życie po to, żeby je przeżyć dobrze. A żeby je przeżyć dobrze, to powinnaś się leczyć. Powinnaś chodzić i sprawdzać swój stan zdrowia” (KST_7_7o); „(Zdrowie zależy - przyp. aut.) od leczenia, od leków. Biorę dużo leków też, na ciśnienie, na krążenie, na takie sprawy, bo jednak postępuje" (KST_16_89). Jak pokazują wyniki sondażu CBOS, blisko połowa (45\%) badanych Polaków w wieku 65 lat i więcej uznaje, że regularne wizyty u lekarza są jednym z najważniejszych prozdrowotnych działań (osoby młode i w średnim wieku wskazywały je znacznie rzadziej) (CBOS 2012a: 87-88). Ponadto starzy ludzie stosunkowo najczęściej przejawiają roszczeniową postawę wobec państwa w zakresie opieki zdrowotnej, wyrażającą się w przekonaniu, że „ochrona naszego zdrowia jest obowiązkiem przede wszystkim państwa, odpowiednich władz” (CBOS 2012a: 15). Ten sposób myślenia wynika z jednej strony z bycia skazanym na służbę zdrowia ze względu na pogarszające się funkcjonowanie organizmu. Z drugiej strony seniorzy dużą część swojego życia przeżyli w czasach dużego zaufania do medycyny ${ }^{6}$

6 Fala krytyki wobec instytucji medycyny miała miejsce pod koniec lat siedemdziesiątych, do czego przyczyniły się wyniki badań nad determinantami zdrowia, pokazujące, że „medycyna ma w skali ogólnospołecznej stosunkowo niewielki wpływ na przeciętną długość życia ludzkiego [...]. Te same badania wskazały 
traktowanej jako „podstawowy klucz do zdrowia i długowieczności” (Ostrowska 1999: 8). Stąd też ich wiara w medycynę naprawczą i przekonanie o jej istotnym wpływie na zdrowie człowieka. Stare respondentki, w związku z koniecznością leczenia się, stosowania odpowiedniej diety itp. mówiły także, co wyróżniało je w grupie uczestniczących w badaniu kobiet, o uwarunkowaniach ekonomicznych zdrowia (dbanie o zdrowie wymagające pieniężnych nakładów) oraz o znaczeniu sprawnej, dostępnej, przyjaznej człowiekowi służby zdrowia, umożliwiającej kontrolowanie stanu zdrowia i leczenie chorób: „Uważam, że każdy człowiek, bez względu na wiek, powinien mieć jakieś kompleksowe badania. Tylko, że nasza służba zdrowia jest taka, że cię to zniechęca" (KST_7_70).

Wiek różnicował również przekonania uczestniczących $\mathrm{w}$ badaniu mężczyzn na temat czynników wpływających na zdrowie. Charakterystyczne dla młodych respondentów było wspominane, cechujące młodych badanych bez względu na płeć, poczucie indywidualnej odpowiedzialności za własne zdrowie, wskazywanie stylu życia, w tym odżywiania jako kluczowych uwarunkowań kondycji psychofizycznej człowieka: „Jeśli dbamy o siebie, o swój styl życia, powiedzmy, kontrolujemy, co robimy danym dniu, to wydaje się, że możemy też kontrolować tym, czy będziemy zdrowi [...]. (Styl życia - przyp. aut.) przede wszystkim świadczy o [...], albo może mówić, dlaczego zachorowaliśmy na daną chorobę" (MM_4_24). Wspominali oni o konieczności ograniczania tzw. śmieciowego jedzenia, fast foodów, jedzenia na mieście, mówili o odpowiednim doborze produktów, wielkości posiłków i częstotliwości/regularności ich spożywania. Podobnie jak respondentki z ich pokolenia podkreślali znaczenie podejmowania przez jednostkę prozdrowotnych działań, co nazywali dbaniem o zdrowie. $\mathrm{W}$ ich przekonaniu to przede wszystkim zachowania człowieka determinują stan jego zdrowia: „Myślę, że można to swoje zdrowie kształtować, można mu zaszkodzić, można mu pomóc po prostu za pomocą przeróżnych decyzji i wyborów" (MM_6_27). Co ciekawe, dbanie o zdrowie w świetle ich wypowiedzi ograniczało się do ubierania się stosownie do pogody, żeby się nie złapać jakiejś infekcji, gdy młode kobiety wspominały o badaniach profilaktycznych: „Głupie założenie szalika czy rękawiczek, które uchroni mnie przed przeziębieniem" (MM_4_24). Respondenci zwracali uwagę, że poprzez swoje zachowania mogą uniknąć choroby i utraty zdrowia bądź wręcz przeciwnie przyczynić się do pogorszenia stanu zdrowia: „Naszymi działaniami

natomiast na istotny wpływ takich czynników, jak elementy stylu życia, wzory odżywiania, aktywność fizyczną, kontakt z używkami (szczególnie alkoholem i tytoniem), materialne środowisko życia i pracy, a także wpływ stresów i posiadania zasobów niezbędnych do uporania się z nimi” (Ostrowska 1999: 7). 
możemy spowodować, wpędzić się w chorobę, tak? Wystarczy, nie wiem, no używki, właśnie złe ubieranie się do pogody, przemarzanie, jedzenie jakiegoś świństwa, no to, to wszystko, nasze działanie może nas wpędzić w chorobę" (MM_1_21).

To, co charakterystyczne dla młodych mężczyzn uczestniczących w badaniu, co też czyniło ich podobnymi do rówieśniczek, to dostrzeganie związku między dbałością o zdrowie i dbałością o wygląd. Z ich wypowiedzi wynika, że takie prozdrowotne działania jak odpowiednie odżywianie czy uprawianie sportu, są motywowane przede wszystkim przez chęć bycia nie tyle zdrowym, co atrakcyjnym fizycznie: „Kwestia dbania o swoją sylwetkę" (MM_14_35). To dowodzi, że część uczestniczących w badaniu mężczyzn z młodego pokolenia przywiązuje dużą wagę do wyglądu, co jest przejawem odchodzenia od patriarchalnej koncepcji męskości, zgodnie z którą „uroda” mężczyzny ma drugorzędne znaczenie - jak głosi porzekadło może on być „trochę ładniejszy od diabła” (Malinowska 2011: 12).

Rozmówcy w średnim wieku wyróżniali się w grupie badanych mężczyzn stosunkowo częstym wskazywaniem na znaczenie genów jako czynnika wpływającego na zdrowie. Może to być efekt uświadomienia sobie przez nich predyspozycji do pewnych schorzeń np. w związku z chorobami rodziców oraz odczuwanymi dolegliwościami, pojawiającymi się wraz z wiekiem. Jednak, jak już zauważono, respondenci - mężczyźni $\mathrm{w}$ przeciwieństwie do uczestniczących w badaniu kobiet częściej traktowali takie genetyczne obciążenie chorobą jako wyrok, wyrażając przekonanie, że nic się z tym nie da zrobić i usprawiedliwiając tym samym swoją bierność w zakresie dbałości o zdrowie: „Wiadomo, że wiele chorób jest związanych z naszą strukturą organizmu. Można chcieć być bardzo zdrowym, a nie móc" (MSR_10_56). Tylko wśród respondentów w tej grupie wiekowej wspomniano także o zdarzeniach losowych - wypadkach jako niezależnych od jednostki czynnikach mających wpływ na ich zdrowie. Warto zauważyć, że częstsze uleganie wypadkom, narażanie się na różnego rodzaju urazy jest statystycznie częstsze wśród mężczyzn w porównaniu z kobietami, co wynika z kulturowej koncepcji męskości. „Ryzykowanie zdrowia i życia, prezentacja odwagi, zręczności i szybkości stanowią zachowania stereotypowo postrzegane jako męskie, natomiast ostrożność, unikanie ryzyka, dbanie o zdrowie, jako zachowania niemęskie" (Królikowska 2011: 391). Respondenci w średnim wieku wskazywali także na funkcjonowanie służby zdrowia - jakość lecznictwa i umiejętności lekarzy - jako, również niezależne od jednostki, uwarunkowania zdrowia. Zwrócili uwagę na znaczenie rozwoju medycyny, wskazując, że obecnie człowiek ma dostęp do różnego rodzaju nowoczesnych badań diagnostycznych oraz możliwości leczenia czy rehabilitacji, czego nie było przed kilkunastu czy kilkudziesięciu laty. 
Uczestnicy badania $\mathrm{w}$ średnim wieku stosunkowo najczęściej w porównaniu z mężczyznami z pozostałych grup wiekowych wypowiadali się na temat zdrowia psychicznego jako czynnika wpływającego na kondycję zdrowotną człowieka (jak już wspomniano, dotyczyło to także respondentek $\mathrm{w}$ średnim wieku). Pojawily się uwagi na temat znaczenia nastawienia do życia w radzeniu sobie z chorobą: ,ja jestem życiowym optymistą [...]. Dlatego staram się nie pieścić, staram się chodzić [...] i to mi pomaga, bo wtedy to się zapomina o tych chorobach i ta rehabilitacja tu postępuje" (MSR_15_61). Poza uwzględnianiem takich aspektów jak podejście do życia, poczucie życiowej satysfakcji i zadowolenia z siebie, wymieniali oni także znaczenie sprawnego umysłu i aktywności umysłowej, o czym nie wspominali młodsi i starsi od nich badani. Wskazywali przy tym na konieczność ciągłego stymulowania mózgu, pobudzania szarych komórek np. poprzez posiadanie jakichś pasji, rozwój zawodowy i rozwój własnych zainteresowań, co pozwala też radzić sobie ze stresem i ograniczać stosowanie używek.

Myślę też, że podejście psychiczne [...], bo ja nie uważam, że człowiek w pewnym momencie musi się zatrzymać, na czymkolwiek, czy na rozwoju zawodowym, czy hobbistycznym, czy własnych, nie wiem, zainteresowań [...]. Jeżeli się rozwija, to muszą komórki szare pracować. Czyli jest ten rozwój, jest ta fascynacja dalej albo i zawodem, albo pasją hobbistyczną. I to daje nam pewne zdrowie psychiczne, nieuciekanie właśnie w jakieś środki odurzające typu: narkotyki albo w jakąś ilość alkoholu, która powoduje, nie wiem, ucieczkę chwilową. I to uważam jest zdrowie psychiczne (MSR_4_40).

Jak wynika z powyższej wypowiedzi, ta szeroko rozumiana aktywność i samorozwój jest alternatywą dla tradycyjnego, męskiego sposobu radzenia sobie ze stresem polegającego na stosowaniu substancji odurzających (Tobiasz-Adamczyk 2000: 124; Ostrowska 2006: 121). Wydaje się, że wskazywanie przez badanych w średnim wieku na znaczenie aktywności umysłowej czy szerzej aktywnego trybu życia i ciągłego rozwoju osobistego jako czynników wpływających na zdrowie wynikać może z lęku przed starzeniem się, przejawiającym się m.in. w dysfunkcjach psychicznych (np. problemy z pamięcią). Być może także średni wiek i związane z nim zadania rozwojowe (Chmura-Rutkowska I., Ostrouch J., 2007) sprzyjają zwiększaniu aktywności na różnych płaszczyznach, podejmowaniu nowych wyzwań, po to, by przekonać samego siebie i innych, że ,jeszcze wszystko przede mną".

Tym z kolei, co wyróżniało starych respondentów wypowiadających się na temat czynników wpływających na zdrowie na tle pozostałych mężczyzn uczestniczących w badaniu, było, podobnie jak w przypadku starych kobiet, wskazywanie wieku jako jednego z uwarunkowań kondycji 
psychofizycznej człowieka. Mówiono o zwiększeniu prawdopodobieństwa pojawienia się różnego rodzaju schorzeń czy dolegliwości związanych $\mathrm{z}$ wiekiem. Co jednak nie pojawiało się $\mathrm{w}$ wypowiedziach starych kobiet, tu zwrócono uwagę na ograniczenia szeroko rozumianej aktywności starego chorego człowieka, jego „spowolnienie”: „bo na przykład nie możesz prowadzić samochodu, to też już jest pewna aktywność, która cię też ogranicza, bo nie [...]. Mając samochód, czy tego, to też możesz sobie, jak to jest świat, jak ktoś jeszcze, pojechać gdzieś, czy tego, mieć kontakty, nie? A tak też, nawet jak tutaj, do kina nie pojedziesz, na imprezę [...]" (MST_3_63). Wskazywano tu zatem na takie konsekwencje starości i pogorszenia zdrowia, które prowadzić mogą do społecznej izolacji jednostki i jej wykluczenia z pewnych obszarów życia społecznego, z kluczowej dla mężczyzny sfery publicznej.

Charakterystyczne dla starych mężczyzn biorących udział w badaniu były także wypowiedzi dotyczące odpowiedzialności jednostki za szkodzenie własnemu zdrowiu, zaniedbywanie go, wpisane w kulturowy model męskości. Respondenci z perspektywy czasu krytycznie oceniali swoje postawy wobec zdrowia, doświadczając negatywnych skutków własnych antyzdrowotnych działań: „No i takie drobiazgi jak czasami siedzący tryb życia, niezajmowanie się własnym zdrowiem, "a bo to samo przejdzie«, na tej zasadzie" (MST_11_71). Obserwowali tym samym szkodliwość patriarchalnego modelu męskości, niepozwalającego im na troskę o zdrowie, skłaniającego ich do ignorowania problemów zdrowotnych, mogących przeszkodzić im np. w aktywności zawodowej (Tobiasz-Adamczyk 2000: 62).

Podsumowując, jak pokazuje analiza wypowiedzi dotyczących czynników wpływających na zdrowie człowieka, kulturowe koncepcje płci i socjalizacja płciowa różnicują przekonania jednostek na ten temat. Uczestniczące w badaniu kobiety zdawały się wykazywać większą świadomością zdrowotną, co przejawiało się w odwoływaniu się przez nie do wiedzy medycznej (np. gdy mówiły o chorobach genetycznych), bardziej kompleksowym spojrzeniu na uwarunkowania zdrowia (np. wskazywanie środowiska naturalnego) oraz poczuciu odpowiedzialności za własną kondycję psychofizyczną. Wskazywały one na konieczność dbania o zdrowie, $\mathrm{w}$ tym zdrowie psychiczne, które $\mathrm{w}$ ich przekonaniu zależy w dużej mierze od „dobrze ułożonego" życia prywatnego, co utożsamiały z posiadaniem potomstwa. W wypowiedziach mężczyzn pojawiły się odwołania do patriarchalnej koncepcji męskości: wspominali oni o znaczeniu pracy zawodowej oraz pozycji materialnej dla zdrowia jednostki. Ponadto wskazywali na takie „męskie” zachowania, jak szkodzenie własnemu zdrowiu poprzez ignorowanie problemów zdrowotnych czy stosowanie używek. Część badanych zdawała się usprawiedliwiać niedbanie 
o zdrowie, podkreślając znaczenie niezależnych od człowieka czynników na nie wpływających (np. źle funkcjonująca służba zdrowia, brak pieniędzy, genetyczne choroby traktowane jako wyrok, z którym nic nie można już zrobić).

Przekonania na temat czynników rzutujących na zdrowie różnicuje nie tylko płeć, ale i wiek, co wiązać można $\mathrm{z}$ jednej strony $\mathrm{z}$ odmiennymi oczekiwaniami stawianymi kobietom i mężczyznom w różnych fazach życia. Z drugiej strony - z socjalizacją pokoleniową, przebiegającą $\mathrm{w}$ innych warunkach społeczno-kulturowych. Młodzi uczestnicy badania częściej niż rozmówcy w średnim wieku i starzy wyrażali przekonanie o indywidualnej odpowiedzialności człowieka za własną psychofizyczną kondycję. To oni przede wszystkim mówili o znaczeniu prowadzonego stylu życia. Osoby ze starszych kategorii wiekowych rzadziej posługiwały się tym pojęciem, mówiąc raczej o "trybie życia”, „sposobie życia”, „prowadzeniu się”, „, higienie życia” czy „higienicznym trybie życia”. Powszechne stosowanie przez młodych określenia „styl życia” świadczy o tym, że w pokoleniu najmłodszych badanych weszło ono „naturalnie" do ich codziennego języka, co jest konsekwencją m.in. obecności tego pojęcia w mediach i mody na "zdrowy styl życia”. Zjawisko to może być jednak także przejawem „prymatu stylu życia” we współczesnym świecie, jak ujmuje to Anthony Giddens (Giddens 2001: 112). Jego zdaniem w późnonowoczesnym społeczeństwie „styl życia stał się czymś koniecznym", jednostka musi dokonywać nieustannego wyboru „W co się ubrać, co zjeść, jak zachowywać się w pracy, z kim spotkać się wieczorem. Wszystkie takie wybory (wraz z tymi poważniejszymi i brzemiennymi w skutki) są nie tylko decyzjami, co robić, ale kim być" (Giddens 2001: 112, 113). Młodzi zdają się być lepiej dostosowani do takiej społecznej rzeczywistości i lepiej rozumieją (jak można by wnioskować z ich wypowiedzi), że tym, co dziś charakteryzuje człowieka, decyduje o jego społecznym statusie i tożsamości, jest właśnie określony styl życia. A ponieważ dorastali oni w czasach upowszechniania się ideologii healthismu, w świetle której zdrowie jest nadrzędną wartością, której podporządkowane powinny być wszystkie sfery życia (Crawford 1980, za: Borowiec, Lignowska 2012), jest dla nich „naturalne”, że styl życia musi uwzględniać dbałość o własne zdrowie, na co wskazuje określanie go w kategoriach „zdrowy” czy „prozdrowotny” (Szpunar 2009). Zdaniem R. Crawforda (1980 za: Borowiec, Lignowska 2012) healthism staje się narzędziem kontroli społecznej: ludzie oceniają siebie nawzajem ze względu na przejawiane postawy wobec zdrowia, „zdrowy/niezdrowy” styl życia. Internalizacja hasła promocji zdrowia "twoje zdrowie w twoich rękach” pociąga za sobą przekonanie o odpowiedzialności za chorobę i poczucia, że choruje się „na własne życzenie”. Eksperci zwracają uwagę na niebezpieczne 
konsekwencje pojawienia się koncepcji „choroby z wyboru”, powiązanej z mechanizmem obwiniania ofiary („sam jesteś sobie winny, że jesteś chory") (Słońska 2010: 218; 2015: 108).

W wypowiedziach młodych wyraz znalazło także poczucie odpowiedzialności za własny wygląd, co wynika z kojarzenia młodości z fizyczną atrakcyjnością. Zauważali oni, że dbanie o zdrowie ściśle wiąże się z dbałością o wygląd, obejmuje bowiem również higienę osobistą czy kształtowanie sylwetki poprzez odpowiednie odżywianie i aktywność fizyczną. Analizując postawy młodych respondentów wobec obu tych zasobów, można odnieść wrażenie, że w pierwszej kolejności dbają oni o atrakcyjność fizyczną, przy okazji osiągając pozytywne efekty zdrowotne.

Pokoleniową różnicę dostrzec można także w wypowiedziach przedstawicieli różnych kategorii wiekowych na temat sposobu odżywiania jako czynnika wpływającego na zdrowie. Osoby w średnim wieku rzadko, stare w ogóle, nie mówily np. o „jedzeniu na mieście”, szkodliwości fast foodów i zaletach domowego jedzenia, bo prawdopodobnie rzadziej spożywają posiłki poza domem i w ich diecie nie pojawia się pizza, hamburgery, frytki itp. Ponadto młodzi dorastali w czasach, w których w mediach, zarówno tradycyjnych (prasa, radio, telewizja), jak i nowych (Internet), wiele miejsca poświęca się zagadnieniom „zdrowego odżywiania się", co wiąże się m.in. z coraz powszechniejszym problemem nadwagi i otyłości, także u dzieci i młodzieży, a pojęcia diety i odchudzania się należą do często używanych. Ponadto, intensywnie rozwija się rynek produktów i usług z zakresu prawidłowego żywienia (produkty określane jako „zdrowe”, „fit”, „ekologiczne”, rozmaite suplementy diety, doradztwo w zakresie żywienia, dietetyki, odchudzania, wczasy odchudzające itp.). Nawet jeśli nie przekłada się to na zachowania prozdrowotne w tej dziedzinie, to na pewno przyczynia się do wzrostu świadomości i poczucia powinności w zakresie odżywiania się, czego dowodem są wypowiedzi młodych respondentów obu płci. Starsze osoby (w średnim wieku i stare), wypowiadając się na temat diety jako czynnika wpływającego na zdrowie, wskazywały głównie na konieczność zmiany wzorów odżywiania w związku z wiekiem i pojawiającymi się problemami zdrowotnymi. Ich wypowiedzi dotyczące odżywiania się (także dotyczące podejmowanych działań prozdrowotnych) są uboższe i bardziej ogólnikowe w porównaniu $\mathrm{z}$ wypowiedziami na ten temat młodych uczestników badania.

Uczestnicy reprezentujący trzy kategorie wiekowe różnie wypowiadali się także na temat ruchu jako czynnika wpływającego na zdrowie. Wynika to $\mathrm{z}$ różnych możliwości motorycznych organizmu uwarunkowanych wiekiem. Młodzi, a także osoby w średnim wieku (tu głównie mężczyźni) podkreślali znaczenie bycia aktywnym fizycznie, wymieniali rodzaje zajęć ruchowych czy sportów, jakie sami uprawiali. Starzy 
badani mówili nie tyle o podejmowaniu aktywności fizycznej, co zachowaniu fizycznej sprawności poprzez bycie w ruchu „w miarę możliwości”. Jak pokazują wyniki sondażu CBOS, osoby po 65 roku życia najrzadziej wskazywały „regularne uprawianie gimnastyki, biegi itp." jako „działanie, które w największym stopniu przyczynia się do poprawy zdrowia ludzi”, podczas gdy respondenci do 35 roku życia traktowali je priorytetowo, zaraz po „zdrowym odżywianiu się” (CBOS 2012a: 87-88). Poza biologicznymi uwarunkowaniami aktywności fizycznej należy jednak wziąć także pod uwagę negatywne stereotypy starości, w świetle których osoby w podeszłym wieku nie są sprawne, a zatem sport nie powinien leżeć w kręgu ich zainteresowań, „nie wypada” im pokazywać się na basenie czy w fitness klubach (nieestetyczne stare ciało wobec kultu młodości). Jak stwierdza Ewa Miszczak:

W Polsce pokutuje »odpowiedni« wzorzec człowieka starego: zajmującego się wnukami, działką, spędzającego wiele czasu w kościele, bez reszty poświęcającego się pomocy rodzinie i niczego w zamian nie oczekującego. $\mathrm{Z}$ obawy przed środowiskowym potępieniem i negatywnymi ocenami, wielu $\mathrm{z}$ seniorów nie podejmuje aktywności innej niż ta »z rozdzielnika" (Miszczak 2010: 26).

Osoby w średnim wieku i stare, częściej niż młodzi wypowiadały się na temat medycyny i służby zdrowia jako czynnika warunkującego zdrowie. Wynika to $\mathrm{z}$ częstszego korzystania $\mathrm{z}$ niej $\mathrm{w}$ związku z pojawiającymi się wraz z wiekiem schorzeniami, a także większego zaufania czy polegania na medycynie badanych ze starszych pokoleń. Młodzi, jak już wspomniano, to $\mathrm{w}$ sobie samych i w swoim stylu życia widzą główny czynnik „odpowiedzialny” za ich kondycję psychofizyczną.

\subsubsection{Powody dbania o zdrowie wskazywane przez kobiety i mężczyzn w różnym wieku (Emilia Garncarek)}

Kontynuując rozważania nad postawami kobiet i mężczyzn wobec zdrowia, $\mathrm{w}$ niniejszym podrozdziale poruszono kwestię powodów dbania o ten zasób. Uczestnicy badania zostali zapytani między innymi o to, czy i dlaczego należy dbać o zdrowie. Wszyscy rozmówcy, bez względu na płeć i wiek odpowiedzieli twierdząco na pierwsze pytanie. Warto zauważyć, że były to pozytywne deklaracje typu: „tak”, „absolutnie”, „oczywiście”, „zdecydowanie tak”, ,jak najbardziej”. Jednak z analizy zebranych danych wynika, że pomimo pozytywnych deklaracji, można wskazać na występowanie różnic pomiędzy kobietami i mężczyznami w przywiązywaniu wagi do zasobu, jakim jest zdrowie. Kobiety, bez względu 
na wiek, wyrażały nie tylko większe zainteresowanie dbaniem o zdrowie, ale także nie wykazywały żadnych wątpliwości w tym aspekcie. U wypowiadających się mężczyzn, pomimo pozytywnych deklaracji, pojawiły się pewne wątpliwości, czy należy dbać o zdrowie. Stwierdzono również rozdźwięk pomiędzy dbaniem o zdrowie na poziomie deklaratywnym a dbaniem o zdrowie w praktyce: „Myślę, że tak, chociaż póki co nie przykładam do niego tak dużej wagi" (MM_3_22). Tylko wśród mężczyzn pojawiły się stwierdzenia zawierające pewne zastrzeżenia, dotyczące tego, czy i jak należy zdrowie pielęgnować. Część z nich zaznaczyła, że oczywiście należy dbać o zdrowie, ale nie mają oni na myśli takiej troski, którą można uznać za przesadną: „Tak (należy dbać o zdrowie - przyp. aut.), ale nie należy popadać w przesadę [...]. No, bo wtedy można wylądować w wariatkowie” (MSR_6_47); „Dbać trzeba, ale bez przesady. Ja po lekarzach nie chodzę, a zdrowy jestem" (MSR_13_60).

Jak już wspomniano, kobiety podkreślały ważność kapitału, jakim jest zdrowie, a także wyrażały większe zainteresowanie dbaniem o nie w praktyce. Ta świadomość znaczenia zdrowia może wynikać m.in. ze specyfiki socjalizowania kobiet, którym to od najmłodszych lat wpaja się jego znaczenie. Kobiety mają być zdrowe, m.in. aby wypełnić przypisane im w patriarchacie role - żony, matki, opiekunki domu. W myśl tego schematu dbanie o zdrowie to domena kobiet, które powinny zajmować się nie tylko własnym zdrowiem, ale także dbaniem o zdrowie swoich najbliższych (dzieci, partnera/męża, starszych rodziców), o czym wspominała większość rozmówców i rozmówczyń, którzy wzięli udział w badaniu (kwestie te będą szerzej omówione w kolejnych podrozdziałach). Pomimo tego że mężczyźni mieli świadomość, że o zdrowie należy dbać, to można tu wskazać na pewną powściągliwość i umniejszanie przez nich tego zasobu kapitału ludzkiego dla funkcjonowania człowieka. Zgodnie z patriarchalnym schematem mężczyzna powinien być silny i sprawny fizycznie, nawet gdy dokuczają mu jakieś dolegliwości zdrowotne. Zatem w pierwszej kolejności powinien dbać o tężyznę fizyczną, która umożliwi mu aktywność zawodową, pozwoli na bycie opiekunem rodziny czy też rywalizowanie z innymi mężczyznami (na niwie zawodowej bądź sportowej), a nie o zdrowie (m.in. Mandal 2003, Renzetti, Curran 2005).

Realizując badanie, zapytaliśmy uczestników nie tylko o to, czy należy dbać o zdrowie, ale również o powody tej troski. Ze szczegółowej analizy wypowiedzi, uwzględniającej płeć badanych, ich wiek oraz „upłciowiony wiek" wynika, że podobnie jak w przypadku poprzednich aspektów składających się na postawy wobec zdrowia, także tutaj wystąpiły różnice pomiędzy poszczególnymi kategoriami badanych. W pierwszej kolejności wskażemy na powody dbania o zdrowie podawane przez kobiety (bez względu na wiek). Będą one przedstawiane według częstotliwości 
występowania - od najczęściej wskazywanych, po te, które były wymienione przez nieliczne badane (analogicznie zostaną przedstawione powody dbania o zdrowie podawane przez mężczyzn).

Odpowiadając na pytanie „dlaczego należy dbać o zdrowie”, rozmówczynie najczęściej wskazywały na strach przed chorobą, która może uniemożliwić normalne, codzienne funkcjonowanie człowieka. Przykładowe wypowiedzi wskazujące na tę przyczynę dbania o zdrowie: „Żeby mieć możliwość normalnego funkcjonowania, tak? Wszystkie uszczerbki na zdrowiu nas ograniczają” (KSR_3_42); „Zdrowie jest dla mnie elementarną sprawą związaną z moim funkcjonowaniem w życiu" (KSR_9_54). Kolejną ważną przyczyną dbania o zdrowie wskazywaną przez badane było zachowanie sprawności fizycznej i niezależność od innych:

Dla mnie to jest bardzo ważne, żeby być zdrowym, bo przeraża mnie wizja bycia chorym. Przeraża mnie wizja, że kiedyś w jakiś sposób mogę doprowadzić do tego, że będę przykuta do łóźka i zależna od kogoś [...]. Widzę, w jaki sposób osoby w moim otoczeniu mają problem ze zdrowiem, są zależne od innych i to mnie przeraża, że za każdym razem będę musiała dzwonić do kogoś po pomoc, żeby ktoś mi kupił leki, bo nie będę mogła wyjść z domu albo żeby ktoś mi coś pomógł, bo nie będę mogła tego zrobić (KM_3_24).

Kobiety podkreślały, że dbanie o zdrowie pozwala zachować niezależność, jednocześnie, zachowując zdrowie nie przysparzamy kłopotów innym - zarówno osobom najbliższym, jak i społeczeństwu: „[...] A jeżeli już zachodzą takie zmiany zwłaszcza w mózgu jakaś kompletna skleroza czy Alzhaimer, że się nikogo nie poznaje, nic się nie wie. No to jest taki ciężar dla społeczeństwa, nie mówiąc już o rodzinie. A jeżeli ktoś nie ma, to jest jeszcze gorzej. Przecież w tych domach opieki też nie jest za przyjemnie" (KST_16_89). Równie ważną przyczyną dbania o zdrowie wskazywaną przez badane było postrzeganie omawianego zasobu jako najwyższej wartości w życiu człowieka: „No bo zdrowie to podstawa. Jak człowiek jest chory, to mu się nic nie chce. Chory, to słaby. No trzeba o nie dbać" (KSR_15_62).

Rozmówczynie podkreślały także, że należy pielęgnować zdrowie, ponieważ nie jest ono dane człowiekowi raz na zawsze. Charakteryzował je pewien rodzaj refleksyjności jeśli chodzi wskazywanie powodów dbania o zdrowie. Ich zdaniem zdrowie jest zasobem, który się wyczerpuje, w związku z tym należy się nim przejmować już w młodym wieku, nawet kiedy nic nam nie dolega:

Zdecydowanie tak, bo jeżeli się o nie (zdrowie - przyp. aut.) nie dba, to bardzo łatwo je stracić (KM_2_24). Myślę, że bardzo trzeba dbać, tylko trzeba mieć świadomość. Szczególnie ludzie młodzi powinni mieć świadomość, 
bo nie wiedzą, nie rozumieją tego, tak, że, że trzeba dbać o zdrowie. Czyli trzeba prawidłowo się odżywiać, wysypiać, nie używać różnych używek, no powiedzmy. Bo gdzieś tam w przyszłości daje efekt jakiś negatywny. Jeżeli będziemy źle postępować w młodości, to na pewno (KSR_10_56).

Badane zaznaczały także, że świadomość ważności tego zasobu pojawia się wraz z wiekiem: „Jak najbardziej (zdrowie jest czymś, o co należy dbać - przyp. aut.). Ale to $\mathrm{z}$ wiekiem przychodzi. Bo jak jesteśmy młodzi, to jesteśmy wszyscy zdrowi, nic się nie dzieje i specjalnie się tym nie przejmujemy, a $z$ wiekiem faktycznie uświadamiamy sobie, że zdrowie jest bardzo istotne i należy o nie dbać" (KM_15_35). Równocześnie wskazywały na znaczenie działań profilaktycznych mających wpływ na utrzymanie zdrowia, były przekonane, że należy brać odpowiedzialność za własne zdrowie, m.in. korzystać z porad lekarzy i kontrolować je poprzez badania profilaktyczne. Ich zdaniem, takie zachowania wpływają także na dobrostan jednostki:

Uważam, że masz życie po to, żeby je przeżyć dobrze. A żeby je przeżyć dobrze, to powinnaś się leczyć. Powinnaś chodzić i sprawdzać swój stan zdrowia (KST_7_70). No bo jeżeli coś zaniedbujemy, to w przyszłości [...]. Jeżeli w coś inwestujemy, to procentuje. Jeżeli zaniedbamy jakieś objawy, to potem może się okazać, za rok, czy za dwa, że jest to coś niebezpiecznego. Czyli lepsza profilaktyka niż leczenie (KSR_6_48).

Następną w kolejności przyczyną dbania o zdrowie wskazywaną przez kobiety było planowanie macierzyństwa lub pełnienie roli matki. Badane podkreślały, że chcą i powinny być zdrowe także dla swoich dzieci, żeby móc wywiązywać się z roli macierzyńskiej, ale także by przekazywać dzieciom „prozdrowotną” postawę: „Teraz odkąd mam dzieci doszedł jakby kolejny argument, dodatkowo jakby powinnam dbać o zdrowie dla dzieci [...]. Poza tym też jestem przykładem dla nich. I to jest też ważne. Bo to jak ja się zachowuję, to jednocześnie uczę ich" (KM_14_35); Zdaniem kobiet troska o zdrowie jest wręcz obowiązkiem, nie tylko wobec siebie. Należy o nie dbać, ponieważ kiedy jest się zdrowym, można pomagać bliskim: „[...] żeby mieć siłę dla dzieci też, dla wnuka w drodze” (KSR_4_45); „No bo chociażby samo to związane z tym, że jeżeli mamy dzieci, to nie możemy niszczyć swojego zdrowia. Czyli uważam, że powinniśmy o niego dbać, dlatego, że jesteśmy potrzebni naszym dzieciom, tak, czy naszym bliskim" (KSR_5_47).

Powyższe cytaty wskazują na odwoływanie się kobiet do genderowo określonej kobiecej powinności/obowiązku dbania o zdrowie, nie tylko swoje, ale także najbliższych. Zgodnie z nią kobiety powinny pielęgnować swoje zdrowie, aby wypełniać przypisane im $\mathrm{w}$ patriarchacie role - matki i opiekunki „ogniska domowego". Jak wynika z analizy 
zebranych danych, kobiety mają silnie zinternalizowane poczucie powinności dbania o nie. Bardziej aktywna postawa zdrowotna kobiet wynika $\mathrm{z}$ wspomnianej już socjalizacji płciowej. Ich częstsze kontakty ( $\mathrm{w}$ porównaniu $\mathrm{z}$ mężczyznami) z lekarzami oraz pogłębiona wiedza dotycząca zdrowia wiąże się także z realizowaną rolą „domowego lekarza", zapewnianiem przez nie opieki zdrowotnej dzieciom i innym członkom rodziny, które przypisane są do tradycyjnego wzorca kobiecości (Tobiasz-Adamczyk 200o). Nieliczne rozmówczynie wspominały, że dbają o zdrowie, żeby dobrze się czuć. Ich zdaniem, zdrowie fizyczne jest podstawą dobrego samopoczucia i zdrowia psychicznego („W zdrowym ciele, zdrowy duch" - KM_7_28), co pociąga za sobą pozytywne nastawienie do życia oraz dobre relacje z innymi ludźmi (KM_7_28). „[...] dbanie o zdrowie procentuje nam tym, że czujemy się dobrze, że mamy energię, siły, chęci do życia po prostu. Do robienia różnych rzeczy" (KM_14_35). Kobiety podkreślały także, że należy dbać o zdrowie również ze względu na fakt, że stanowi ono warunek życia, a także chęć życia jak najdłużej: „Jeśli jesteśmy zdrowi, i fizycznie i psychicznie, to chce się nam żyć, to chce się nam iść do przodu, jakoś myśleć o przyszłości” (KSR_4_45).

W odróżnieniu od mężczyzn, którzy wzięli udział w badaniu, tylko nieliczne kobiety wskazały na konieczności troski o zdrowie ze względu na realizowanie różnych ról w życiu publicznym. Część z nich wspominała o dbaniu o zdrowie ze względu na studiowanie oraz pracę zawodową (kobiety młode) lub w kontekście różnego rodzaju prac wykonywanych w domu oraz w kontekście pracy zawodowej: „Dlaczego należy o nie dbać? Bo jak człowiek jest zdrowy to wszystko może. Dobrze pracować, dobrze funkcjonować w domu, w pracy, no wszystko może" (KSR_14_53). Pojedyncze wypowiedzi dotyczyły przyczyn ekonomicznych. Badane wspomniały, że należy dbać o zdrowie, ponieważ chorowanie wiąże się z wydatkami: „Głównie to, żeby nie być zależną od innych, żeby nie mieć problemu, żeby nie wydawać multum pieniędzy na lekarstwa, żyjemy w takim kraju, że one są cholernie drogie, więc wolałbym pozostać jak najdłużej w pełni sił" (KM_3_24). Należy tu zwrócić uwagę na wskazania, które pojawiły się tylko w wypowiedziach kobiet. Dotyczyły one konieczności pielęgnowania swojego zdrowia ze względu na to, że życie i zdrowie są darami od Boga. W związku z tym człowiek zobligowany jest dbać o zdrowie, by z tego daru korzystać jak najdłużej, by go nie zmarnować: „O zdrowie należy dbać $\mathrm{z}$ różnych względów. Zaczynając od względów religijnych, że dostaliśmy to życie od Boga i jest naszym obowiązkiem dbanie o to, żeby to ciało było w dobrej kondycji, to po pierwsze" (KM_14_35). W porównaniu do mężczyzn kobiety nie wspominały o dbaniu o zdrowie, aby 
ustrzec się konieczności kontaktowania się ze służbą zdrowia. Jak wyni$\mathrm{ka} \mathrm{z}$ analizy wypowiedzi badanych, są one przyzwyczajone do tego typu kontaktów i korzystanie z porad lekarskich nie jest dla nich tak problematyczne jak dla mężczyzn.

Jeśli chodzi o mężczyzn, którzy odpowiadali na pytanie „dlaczego należy dbać o zdrowie", to należy podkreślić, że częściej niż kobiety odwoływali się do sloganów typu „zdrowie jest najważniejsze”, „człowiek ma tylko jedno zdrowie". Rozmówcy zwracali uwagę na znaczenie zdrowia w kontekście wartości, życiowego priorytetu, jednakże nie wskazywali tak szczegółowo jak kobiety, dlaczego należy dbać o ten zasób: „No w sumie zdrowie jest najważniejsze. Bo jak zdrowia nie ma, to nic nie ma" (MM_9_33); „Myślę, że jest ważne, ale mam podejście jak we fraszce Kochanowskiego, nie wiesz, czym jest zdrowie, póki go nie stracisz, i to tak chyba u mnie jest, szczerze mówiąc" (MSR_3_40). Podobnie jak kobiety, które wzięły udział w badaniu, większość $\mathrm{z}$ wypowiadających się mężczyzn deklarowała, że należy dbać o zdrowie, aby uniknąć chorób i problemów zdrowotnych, które mogą utrudnić normalne funkcjonowanie człowieka. Jednak to kobiety, częściej niż mężczyźni, wskazywały na ten powód dbania o zdrowie. Charakterystycznym jest również to, że kobiety zwracały uwagę na inne aspekty tzw. „normalnego” działania człowieka niż mężczyźni. U mężczyzn pojawiły się uwagi dotyczące funkcjonowania $\mathrm{w}$ środowisku zawodowym, na co wskazywały jedynie nieliczne rozmówczynie. Normalne, codzienne działanie było wiązane przez mężczyzn przede wszystkim $\mathrm{z}$ funkcjonowaniem $\mathrm{w}$ środowisku pracy, a także wiązało się z realizowaniem różnych planów życiowych:

Myślę, że zdrowie to jest podstawa, bo jeżeli człowiek jest chory, to wszystko się wiąże z tym. Nie może pracować, nie może w koło siebie robić, nie może pracować w domu, pomagać rodzinie, jest zależny od drugiego człowieka” (MSR_2_39). „[...] np. żeby gdzieś pojechać, gdzieś pójść, do tego wszystkiego jest potrzebne ogólne zdrowie, jakieś takie. Nie mówię już do przesady, ale aby cokolwiek zrealizować np. pojechać na wakacje, to też jest potrzebne zdrowie (MSR_6_47).

Charakterystyczne dla tej grupy badanych było podkreślanie, że dbają o zdrowie nie tylko dla samego zdrowia, lecz dla przyjemności i satysfakcji z działań podejmowanych na rzecz swojego zdrowia. Dla niektórych mężczyzn dbanie o zdrowie stanowiło źródło lepszego samopoczucia, nie tylko fizycznego, także psychicznego. Warto w tym miejscu przypomnieć, że badani mężczyźni kojarzyli troskę o zdrowie przede wszystkim z dbaniem o sprawność fizyczną. Wskazywali, że należy pilnować zdrowia, by móc jak najdłużej prowadzić aktywny tryb życia, uprawiać sport, a także mieć siłę do rywalizacji z innymi (na niwie zawodowej i/lub sportowej): 
Także do tych wszystkich diet i ćwiczeń jestem bardziej motywowany chęcią takiego selfesteemu niż zdrowiem. Zdrowie jest dużo mniejsze dla motywacji. Bardziej żeby się lepiej czuć (MSR_3_40). Lepiej się czuję, jak pójdę na basen. No po prostu moje ciało mówi mi: »Wymęczony jesteś człowieku, ale zobacz, jak fajnie teraz jest«. I rzeczywiście tak jest. Jak załatwię jakąś rzecz, z którą mam problem, to znowu psychika mówi: »Daliśmy sobie radę! I kolejnym razem też damy radę!«" (MSR_4_40).

Zdaniem mężczyzn należy dbać o zdrowie również dlatego, że od jego stanu zależy życiowa satysfakcja: „Będąc zdrowym, wysportowanym, atrakcyjnym ta ochota do życia i do wyjścia do ludzi jest chyba zdecydowanie większa, a chyba o to chodzi w naszej egzystencji, żeby no jednak się socjalizować i w ogóle w tym całym [...]” (MM_7_28). O ile kobiety charakteryzowała większa refleksyjność w odniesieniu do omawianego aspektu, o tyle postawy mężczyzn były bardziej reaktywne. Dbanie o zdrowie wiązali przeważnie z działaniami służącymi przezwyciężeniu zaistniałych problemów, a także odczuwaniem dyskomfortu psychofizycznego. Warto tu jeszcze dodać, że pojedyncze wypowiedzi badanych dotyczyły powiązania pielęgnacji zdrowia z funkcjonowaniem w życiu rodzinnym. Nieliczni mężczyźni zaznaczyli, że kiedy jest się sprawnym, można być aktywnym w życiu dzieci, bawić się z nimi, np. grać z nimi w piłkę:

[...] żeby dalej uczestniczyć aktywnie w życiu dzieci to myślę, że takie coś jest ważne” (MM_12_32). [...] będąc dłużej w zdrowiu, na przykład będąc już starszy, będę mógł dzieci uczyć gry w piłkę, nauczyć ich wielu innych rzeczy, na które pozwala właśnie zdrowie, a nie leżeć w łóżku i chorować na jakieś choroby. Tylko po prostu będę mógł aktywnie spędzać czas ze znajomymi, z dziećmi (MM_3_22).

Również w przypadku tych wypowiedzi zaobserwowano różnice pomiędzy postawami kobiet i mężczyzn - kobiety częściej dbają o zdrowie, żeby móc pomagać dzieciom bądź wnukom, natomiast mężczyźni - by móc się z nimi bawić, uprawiać z nimi sport. Zgodnie z płciowym podziałem ról i sfer aktywności w polskich rodzinach to kobiety przede wszystkim zajmują się prowadzeniem domu i opieką nad dziećmi, natomiast mężczyźni w dużej mierze skupiają się na obszarze życia zawodowego, a opiekę nad potomstwem powierzają żonie/partnerce. Zaangażowanie ojców pojawia się dopiero wtedy, kiedy dziecko jest starsze, nie ma problemu z komunikowaniem się, wtedy też ojcowie zaczynają budować z nim relację, bardzo często opartą na wspólnej zabawie (m.in. Titkow, Duch-Krzysztoszek, Budrowska 2004, Sikorska 2009, 2012, CBOS 2013b, Dzwonkowska-Godula 2015). Z analizy zebranych danych wynika, że wskazując na powody dbania o zdrowie, badani odwoływali się 
do stereotypowego podziału, w którym to mężczyzna/ojciec jest „od zabawy" (gra z dzieckiem w piłkę, chodzi z nim na basen, jeździ na rowerze itp.), a kobieta/matka od „wychowywania/opieki nad dzieckiem” (przygotowuje posiłki, karmi, dba o czystość, pilnuje szczepień oraz wizyt lekarskich itp.). Nieliczni mężczyźni podkreślali również, że dbając o zdrowie, unikamy problemów zdrowotnych, możemy jak najdłużej prowadzić aktywny tryb życia i tym samym być niezależnym od innych. Zachowanie dobrej kondycji psychofizycznej stanowi podstawę zachowania niezależności. Choroba, zdaniem mężczyzn, powoduje, że stajemy się ciężarem dla innych osób, jesteśmy obciążeniem dla najbliższych. W przypadku choroby bądź niedołężności obarczamy ich obowiązkiem fizycznej opieki nad nami, tym samym przysparzamy członkom rodziny zmartwień: „Myślę, że zdrowie to jest podstawa, bo jeżeli człowiek jest chory, to wszystko się wiąże z tym. Nie może pracować, nie może w koło siebie robić, nie może pracować $\mathrm{w}$ domu, pomagać rodzinie, jest zależny od drugiego człowieka. Myślę, że zdrowie jest dla każdego, przynajmniej powinno być dla każdego najważniejsze" (MSR_2_39).

Wśród powodów dbania o zdrowie wskazywano także chęć uniknięcia chorób i problemów zdrowotnych, które mogą się wiązać z ograniczeniami i koniecznością zmiany dotychczasowego stylu życia:

Jak się już raz je (zdrowie - przyp. aut.) straci, no to już jest trudno to odzyskać, tak? Generalnie nawet jest już to w pewnych momentach niemożliwe, ponieważ jak się rozwali jakoś nerkę albo wątrobę, to już potem trzeba cały czas trzymać dietę i spożywać jakieś suplementy diety i tego typu rzeczy, tak? Żeby wszystko mniej więcej działało tak jak powinno (MM_5_26).

Nieliczni rozmówcy wskazali, że należy dbać o zdrowie, ponieważ jest ono zasobem, który można stracić, jeśli się o niego nie dba. Jednakże w przeciwieństwie do wypowiadających się kobiet, które zwróciły uwagę, że świadomość zdrowotną nabywa się z wiekiem, mężczyźni zdają sobie sprawę, że należy dbać o zdrowie dopiero wtedy, kiedy je tracą, podupadają na zdrowiu: „Myślę, że powinno się o to dbać. Ja dopiero sobie zdaję sprawę, jak podupadłem na zdrowiu, to zacząłem sobie zdawać sprawę, że tego nie można, tego można, no i dążyłem do tego, żeby nie przeholować, żeby nie pogorszyć sprawy." (MST_12_72). Część badanych zwróciła także uwagę na ekonomiczne aspekty zdrowia i choroby. Ich zdaniem, jeśli nie dbamy o zdrowie, to $\mathrm{w}$ przypadku choroby leczenie może wiązać się z ponoszeniem dużych nakładów finansowych:

To jest jakby nawiązanie do finansowej strony, pomijając już sprawę zdrowotną jako taką, to na pewno koszty większe na doprowadzenie się do porządku, czyli na leki, na jakieś zabiegi, różne, rehabilitacyjne (MST_11_71). 
Należy zaznaczyć, że żaden z wypowiadających się mężczyzn nie wyraził przekonania o tym, że o zdrowie należy dbać, ponieważ jest darem od Boga, a także, żeby móc pomagać swoim dzieciom bądź wnukom (ewentualnie, aby móc spędzać z nimi wolny czas, bawić się z nimi). Mężczyźni nie wskazali również na chęć życia jak najdłużej jako przyczyny dbania o zdrowie. Jak już wspomniano, powody te wymieniały kobiety, które wzięly udział w badaniu.

$\mathrm{Z}$ analizy zebranych danych wynika, że wskazując na powody dbania o zdrowie, mężczyźni nawiązują do tradycyjnego/patriarchalnego wzorca męskości, w którym to omawiany zasób nie stanowi tak znaczącej wartości jak np. siła fizyczna i możliwość jej wykorzystania, przede wszystkim podczas aktywności zawodowej, sportowej bądź towarzyskiej. Kobiety zaś wskazywały na znaczenie zdrowia jako ważnego zasobu kapitału ludzkiego mającego wpływ na ich funkcjonowanie w różnych obszarach życia, zwłaszcza rodzinnego. Zatem wyniki analizy wypowiedzi kobiet i mężczyzn, reprezentujących różne kategorie wiekowe, na temat powodów dbania o swoje zdrowie, weryfikują postawioną przez nas hipotezę mówiącą o tym, że kobiety chętniej niż mężczyźni postrzegają zdrowie jako zasób kapitału ludzkiego mający wpływ na ich społeczne funkcjonowanie.

Istotna różnica pomiędzy kobietami a mężczyznami wypowiadającymi się na temat powodów dbania o zdrowie pojawiła się również na poziomie języka. Kobiety odwoływały się do takich określeń jak „strach”, „obawa” przed chorobą, natomiast mężczyźni - dbam o zdrowie, ponieważ chcę „uniknąć chorób” bądź „problemów zdrowotnych". Zgodnie ze schematem tradycyjnych ról kobiecych wzorzec reakcji w sytuacjach trudnych polega na analizowaniu uczuć; kobiety mają również większe przyzwolenie na jawne wyrażanie lęku, natomiast manifestowanie lęku przez mężczyzn kojarzone jest ze słabością i może być interpretowane jako niemęskie (por. Frąckowiak-Sochańska 2011).

Gdy w analizie wypowiedzi badanych, zarówno kobiet, jak i mężczyzn, uwzględnimy wiek, okazuje się, że osoby młode, w średnim wieku i stare wskazują na nieco inne powody dbania o zdrowie. W pierwszej kolejności zostaną omówione przyczyny troski o zdrowie wskazywane przez kobiety reprezentujące wyodrębnione trzy kategorie wiekowe.

Młode uczestniczki badania zwracały szczególną uwagę na możliwość normalnego funkcjonowania, jednakże „normalne funkcjonowanie” było rozumiane przez nie jako sposobność „korzystania z życia”, oznaczało również brak wydatków na leczenie oraz możliwość prowadzenia samodzielnego, niezależnego życia. Zdaniem młodych kobiet, choroba może zakłócić funkcjonowanie człowieka i przyczynić się do wielu ograniczeń (np. związanych $\mathrm{z}$ konieczności rezygnacji ze studiowania, 
świadczenia/wykonywania pracy zawodowej lub z aktywności towarzyskiej). Również kobiety w średnim wieku zwróciły uwagę na tę przyczynę dbania o zdrowie, ale powiązały „normalne funkcjonowanie” przede wszystkim z perspektywą codziennej aktywności - w życiu prywatnym (m.in. dbanie dom, opieka nad dziećmi) oraz w życiu zawodowym. Podkreślały także, że dbają o zdrowie, aby móc zachować niezależność oraz nie być zdanym na pomoc innych: „Tylko i wyłącznie w kontekście chyba tylko tego egoistycznego podejścia żebym nie musiała być zdana na łaskę i nie łaskę innych. Żebym mogła sam zrobić to co chcę" (KSR_7_49). Ta sama przyczyna była wskazywana także przez kobiety starsze. Jednakże „normalne funkcjonowanie” było przez nie rozumiane jako dobre samopoczucie oraz „korzystanie jeszcze z życia”. „Jeśli jest się zdrowym i to zdrowie zagospodarowuje na uciechy, przyjemności" (KST_6_69); „No bardzo ważne zdrowie jest, wie pani. No bo człowiek po co żyje, po to żeby umilał ten czas jeszcze, no nie?" (KST_3_65). Tylko dwie starsze kobiety zwróciły uwagę na fakt, że należy zdecydowanie dbać o zdrowie, ponieważ daje ono siłę do życia oraz pracy: „Bo to nam daje siłę do życia, do pracy przede wszystkim" (KST_10_71). Jak wskazały badane, na podejście do zdrowia i troskę o nie wpływa również fakt bycia matką. Młode kobiety podkreślały, że chcą i powinny być zdrowe także dla swoich dzieci, żeby móc wywiązywać się z roli rodzicielskiej, ale także by przekazywać im „prozdrowotną" postawę, natomiast kobiety będące w średnim wieku oraz kobiety starsze podkreślały zaś, że należy dbać o zdrowie, aby móc jak najdłużej pomagać swoim dzieciom, wnukom bądź nie być dla nich obciążeniem. Wśród wypowiadających się młodych kobiet znalazły się również pojedyncze stwierdzenia, że należy dbać o zdrowie, ponieważ jest ono darem od Boga, o który należy się troszczyć. Do tej przyczyny dbania o zdrowie nawiązywały również nieliczne reprezentantki najstarszej kategorii wiekowej kobiet (na tę przyczynę dbania o zdrowie nie wskazywały kobiet będące $\mathrm{w}$ średnim wieku). Młode rozmówczynie wspominały także, że zdrowie nie jest dane człowiekowi raz na zawsze, jest kruchym zasobem, który można stracić, jeśli nie będzie się o nie dbać. Pojawiły się tutaj uwagi, że świadomość ta przychodzi $z$ wiekiem oraz gdy zaczynają się pojawiać jakieś zdrowotne problemy czy dolegliwości. Na tę przyczynę dbania o zdrowie wskazywały również kobiety w średnim wieku, które wspominały jednocześnie, że powinno się stosować profilaktykę i dbać o zdrowie już w młodym wieku. Same jednak zaznaczyły, że świadomość i ważność profilaktyki zdrowotnej pojawia się dopiero w późniejszym wieku. Respondentki reprezentujące najstarszą kategorię wiekową nie wspominały o tej przyczynie dbania o zdrowie. Jak wynika $\mathrm{z}$ deklaracji starszych kobiet, ten kruchy zasób został już częściowo utracony, a kobiety te, w porównaniu 
do młodszych badanych, obecnie przywiązują więcej wagi do medycyny profesjonalnej. Młode kobiety podkreśliły, że należy dbać o zdrowie fizyczne, ponieważ jest podstawą dobrego samopoczucia i zdrowia psychicznego. Nieliczne reprezentantki średniego wieku również łączyły te dwa zasoby zdrowia. Zarówno kobiety w średnim wieku, jak i kobiety starsze odwołały się do pewnego rodzaju oczywistych stwierdzeń, podkreślających że zdrowie jest najwyższą wartością w życiu człowieka, jest „wartością fundamentalną" (KST_6_69); „Zdrowie jest najważniejsze w życiu, wszystko inne się nie liczy, najważniejsze jest zdrowie" (KSR_14_53); „No bo zdrowie to podstawa. Jak człowiek jest chory, to mu się nic nie chce. Chory to słaby. No trzeba o nie dbać" (KSR_15_62). Podobnie jedna $\mathrm{z}$ kobiet zauważyła, że dbanie o zdrowie stanowi warunek życia i właśnie to jest powodem, dla którego należy to robić: „Jeśli jesteśmy zdrowi, i fizycznie i psychicznie, to chce się na żyć, to chce się nam iść do przodu, jakoś myśleć o przyszłości” (KSR_4_45).

Charakterystyczne dla młodych kobiet w omawianym aspekcie postawy wobec zdrowia było niewskazywanie jako przyczyn dbałości o zdrowie chęci uniknięcia kontaktu z lekarzami czy też polską służbą zdrowia. Natomiast żadna $\mathrm{z}$ reprezentantek średniego wieku nie wyraziła przekonania o tym, że o zdrowie należy dbać, ponieważ jest ono źródłem lepszego samopoczucia lub przyjemności (takie wskazania znalazły się u młodszych i starszych kobiet oraz u mężczyzn), jak również, że dzięki dbaniu o zdrowie można uniknąć kontaktu $\mathrm{z}$ negatywnie ocenianą polską służbą zdrowia. Wskazały natomiast, że dbają o zdrowie z powodu chęci życia jak najdłużej: „Ma znaczenie, no zdrowie mi się jakoś tak kojarzy z umieraniem, więc im będę zdrowsza, tym będę dłużej żyła. Mam tyle rzeczy do zrobienia, że chciałabym bardzo długo żyć" (KSR_8_53). Jak już wspomniano wcześniej, również z chęci bądź konieczności pomagania swoim bliskim.

Należy zaznaczyć, że starsze badane miały problemy z udzieleniem szczegółowej odpowiedzi na pytanie „dlaczego należy dbać o zdrowie? Nie potrafiły one wskazać konkretnych powodów. Bardziej zrozumiałym dla rozmówczyń w tym wieku było pytanie o to, czy zdrowie jest ważne bezpośrednio dla badanej i dlaczego jest istotne (kwestia ta została omówiona w komponencie afektywnym postawy wobec zdrowia). Odpowiadając na pytanie „dlaczego należy dbać o zdrowie”, część z nich wskazała na znaczenie dbania o zdrowie w celu zapobiegania chorobom i tym samym nie przysparzania kłopotów innym - nie tylko najbliższym, ale także społeczeństwu, na co nie wskazywały młodsze badane. Również nieliczne starsze kobiety podkreśliły, że należy troszczyć się o zdrowie, ponieważ wpływa ono na dobrostan jednostki. Ich zdaniem, aby utrzymać dobre zdrowie, należy korzystać z porad lekarzy i kontrolować je 
poprzez badania profilaktyczne: „Uważam, że masz życie po to, żeby je przeżyć dobrze. A żeby je przeżyć dobrze, to powinnaś się leczyć. Powinnaś chodzić i sprawdzać swój stan zdrowia" (KST_7_70).

Analizując przytoczone powody dbania o zdrowie, można wskazać na występowanie generacyjnych różnic w postawach wobec zdrowia kobiet reprezentujących różne kategorie wiekowe. Wynikają one nie tylko ze stanu zdrowia - kobiety starsze, ze względu na gorszy stan zdrowia i związane $\mathrm{z}$ wiekiem problemy zdrowotne, więcej wagi przywiązują do kwestii związanych z samopoczuciem, odczuwaniem bądź brakiem bólu, natomiast kobiety młodsze, definiując „normalne funkcjonowanie", nawiązują do pełnionych ról społecznych, tj. pracownica, matka. Jak wynika $z$ analizy zebranych danych, przede wszystkim reprezentantki średniego wieku nawiązują do wcześniej już wskazanych genderowo określonych kobiecych powinności (obowiązku dbania o zdrowie, nie tylko swoje, ale także najbliższych, opieki nad dziećmi oraz łączenia pracy zawodowej z obowiązkami domowymi). Można je również zakwalifikować do „pokolenia przegubowego"/ „sandwich generation”. Określenie to zostało ukute przez Dorothy Miller. Pierwotnie odnosiło się do kobiet trzydziesto- i czterdziestoletnich, które dbają o swoje dzieci, ale jednocześnie dbają o potrzeby starzejących się rodziców, a także dalszej rodziny bądź przyjaciół (Miller 1981). Współcześnie to grupa czterdziesto- i pięćdziesięciolatków, żyjących niejako „w kanapce", rozdartych pomiędzy opieką nad starszymi rodzicami a własnymi dziećmi bądź wnukami. Najbardziej w tę „kanapkę" uwikłane są kobiety ok. pięćdziesiątego roku życia. To one troszczą się o zniedołężniałych rodziców i teściów, wspierają własne, dorastające dzieci, bawią wnuki, zajmują się nie tylko własnym gospodarstwem domowym - sprzątają, gotują, robią zakupy również dla starzejących się rodziców bądź nie do końca usamodzielnionych dzieci (Diller 2012). Uwikłanie w genderowo określone powinności powoduje, że niektóre z nich często zmuszone są do porzucenia pracy zawodowej, nawet na kilka lat przed planowaną emeryturą. Z powodu zaangażowania w życie rodzinne dla niektórych kobiet to również okres, w którym przestają dbać o swoje zdrowie (kwestie te zostaną omówione w komponencie behawioralnym postaw wobec zdrowia).

Również w przypadku mężczyzn wystąpiło kilka charakterystycznych powodów dbania o zdrowie, na które wskazywali reprezentanci poszczególnych kategorii wiekowych. Jeśli chodzi o młodych mężczyzn, to zaznaczali oni, że zdrowie umożliwia aktywność zawodową (powód wskazywany również przez pozostałych badanych), a także utrzymywanie kontaktów z innymi ludźmi, przede wszystkim ze znajomymi, no co nie zwracali uwagi pozostali mężczyźni, a także kobiety, które 
wzięły udział w badaniu. Młodzi mężczyźni skupiali się również na takich aspektach jak życiowa satysfakcja, energia, dobre psychiczne samopoczucie, zadowolenie $z$ siebie, a także sprawność. Zauważali, że od stanu zdrowia zależy jakość oraz długość życia. Ich zdaniem należy dbać o zdrowie, ponieważ w przypadku wystąpienia choroby jesteśmy zmuszeni do zmiany stylu życia, możemy mieć problem ze zrealizowaniem planów i marzeń. Wskazywanie przez młodych mężczyzn na psychofizyczne aspekty zdrowia oraz na styl życia jako ważnych elementów $\mathrm{w}$ omawianym aspekcie oraz wyrażanie przekonania o indywidualnej odpowiedzialności za własną kondycję psychofizyczną, może wynikać z faktu, że dorastali oni w kulturze, w której propaguje się modę na zdrowy styl życia oraz ideologię healthismu. Mężczyźni ci, w przeciwieństwie do reprezentantów starszego pokolenia, mają większą świadomość znaczenia zdrowia, a część z nich wykorzystuje tę wiedze również w praktyce. Należy podkreślić, że wśród mężczyzn tylko młodzi badani zwrócili uwagę na fakt pełnienia roli ojca jako przyczyny dbania o zdrowie. Ich zdaniem należy być zdrowym, alby móc zająć się swoimi dziećmi. Jednakże skupiali się oni przede wszystkim na wadze bycia aktywnym ojcem, tzn. takim, który ma zdrowie i siłę na zabawę z dziećmi. Tym samym młodzi mężczyźni wskazywali nie tylko na aktywność $\mathrm{w}$ sferze publicznej, m.in. związaną z pracą zawodową, ale także zaangażowanie w życie rodzinne. Analiza wypowiedzi respondentów, którzy wzięli udział $\mathrm{w}$ naszym badaniu, a także wyniki innych badań nad problematyką współczesnych wzorów kobiecości i męskości, pokazuje, że współcześni młodzi mężczyźni coraz częściej angażują się właśnie w pełnienie roli rodzicielskiej i życie rodzinne (m.in. Sikorska 2009, 2012, Szlendak 2010, Dzwonkowska-Godula 2015). Wśród powodów dbania o zdrowie młodzi mężczyźni wskazywali także na chęć uniknięcia chorób i problemów zdrowotnych, które utrudniają życie, nie tylko własne, ale także najbliższych. Wyrażono również przekonanie, że zdrowie jest zasobem, o który należy dbać, bo w przeciwnym razie się go straci. Powody te były wymieniany również przez mężczyzn będących w średnim wieku.

Charakterystycznym dla reprezentantów średniego wieku powodem dbania o zdrowie była przede wszystkim chęć zachowania dobrej kondycji psychofizycznej, umożliwiającej zachowanie niezależności od innych. Mężczyźni ci chcieliby ustrzec się przed obciążeniem bliskich osób ewentualnym obowiązkiem fizycznej opieki nad nimi oraz przed przysporzeniem członkom rodziny zmartwienia, które może negatywnie wpływać także na ich zdrowie. Takie stwierdzenia nawiązują do tradycyjnej koncepcji męskości, w której mężczyzna nie okazuje słabości. Chorowanie nie mieści się $\mathrm{w}$ tradycyjnym wizerunku mężczyzny 
- silnego, twardego, nie potrzebującego pomocy (m.in. Mandal 2003, Ostrowska 2006, Królikowska 2011). „Bo dzięki temu, że ja powiedzmy jestem zdrowy i w miarę się jakoś trzymam, nie narzekam, bo nie dosięgły mnie jakieś poważne choroby. No to nie przysparzam komuś jakichś tam problemów, kłopotów, jakichś zmartwień” (MSR_8_53). Tylko mężczyźni będący w średnim wieku zaznaczyli, że dbanie o zdrowie stanowi źródło lepszego samopoczucia (psychicznego), a także, że może być źródłem przyjemności. Jest to kategoria, która nie wystąpiła u pozostałych badanych obojga płci. Część mężczyzn reprezentujących tę kategorię wiekową wspomniała, że dba o zdrowie nie dla samego zdrowia, lecz dla przyjemności i satysfakcji z działań podejmowanych na rzecz swojego zdrowia. Należy tutaj wziąć pod uwagę jak mężczyźni rozumieją pojęcie zdrowia - przede wszystkim jako aktywność fizyczną i sportową. Analizując kwestie przyczyn dbania o zdrowie, tę przyjemność i satysfakcję z działań na rzecz zdrowia łączyli z możliwością rywalizacji, m.in. na niwie sportowej: „Ja to robię, także ja mam w tym przyjemność. Wymyślam, namawiam, proponuję, a to jakąśs siatkę do speedtona, staram się to na tyle uatrakcyjnić, żeby to był element poznawczy, stąd też rower, to jest po coś" (MSR_14_61). Reprezentanci średniego wieku zaznaczali również, że zdrowie stanowi priorytetową wartość w życiu człowieka, jest także „warunkiem życia w ogóle”, na co nie wskazywali pozostali badani mężczyźni. W dodatku u większości mężczyzn w średnim wieku pojawia się uwaga dotycząca funkcjonowania w środowisku zawodowym, na co zwracali uwagę tylko nieliczni młodzi i starsi badani:

Myślę że zdrowie to jest podstawa, bo jeżeli człowiek jest chory, to wszystko się wiąże z tym. Nie może pracować, nie może $\mathrm{w}$ koło siebie robić, nie może pracować $\mathrm{w}$ domu, pomagać rodzinie, jest zależny od drugiego człowieka (MSR_2_39). No tak, jest ważne (zdrowie - przyp. aut.). Gdybym nie był zdrowy, np. miałbym chory kręgosłup, to nie mógłbym pracować [...] (MSR_6_47).

Analizując zebrane wypowiedzi, również tutaj spostrzeżono nawiązywanie mężczyzn w średnim wieku do aktywność w sferze publicznej, zawodowej, co odpowiada patriarchalnemu modelowi męskości. Żaden z rozmówców w tej kategorii wiekowej nie wyraził przekonania o tym, że o zdrowie należy dbać, ponieważ chce się pomagać swoim dzieciom, bądź, że chce żyć jak najdłużej, na co wskazywały kobiety z tej samej kategorii wiekowej.

Charakterystycznym dla starszych mężczyzn było natomiast wskazywanie na lekceważenie swojego zdrowia $\mathrm{w}$ młodości i zainteresowanie się nim dopiero wtedy, kiedy pojawiły się poważne problemy 
zdrowotne: „Myślę, że powinno się o to dbać. Ja dopiero sobie zdaję sprawę jak podupadłem na zdrowiu, to zacząłem sobie zdawać sprawę [...]" (MST_12_72). Jak podkreślali niektórzy z nich, nawet kiedy zaczęli borykać się z różnymi dolegliwościami, to część z nich lekceważyła je. Dopiero dzięki namowom rodziny - żony lub córki, zaczęli diagnozować swoje zdrowie oraz stosować się do zaleceń lekarskich. Część badanych, zapytanych o to, czy i dlaczego należy dbać o zdrowie, odwoływała się do innych osób, które namawiają ich do tego działania lub zajmują się ich zdrowiem: „Tak, oczywiście. Myślę, że my dbamy. Tzn. ja z żoną. No ona może bardziej, bo na tę tarczycę też choruje, ale ja też. Ona mnie też zawsze przypilnuje. $\mathrm{Z}$ tymi ziołami, z dietą [...]" (MST_8_70). Również tylko starzy mężczyźni zwrócili uwagę na kwestie ekonomiczne związane z dbaniem o zdrowie. Nie pojawiły się one u pozostałych mężczyzn, którzy wzięli udział w badaniu. Reprezentanci najstarszego pokolenia podkreślali, że o zdrowie należy dbać, żeby ustrzec się wydatków związanych $\mathrm{z}$ leczeniem $w$ razie wystąpienia choroby/chorób: [...] to jest jakby nawiązanie do finansowej strony, pomijając już sprawę zdrowotną jako taką, to na pewno koszty większe na doprowadzenie się do porządku, czyli na leki, na jakieś zabiegi, różne, rehabilitacyjne" (MST_11_71). To, co odróżniało starszych mężczyzn od pozostałych badanych, to porównywanie swojego zdrowia oraz dbania o nie z dbaniem o samochód: „Oczywiście tylko nie dbamy. Ja to zawsze tak tłumacze. Bardziej dbamy o samochód, żeby mieć pieniądze [...]" (MST_6_66).

W analizie powodów dbania o zdrowie wskazywanych przez kobiety i mężczyzn uwzględniliśmy także „upłciowiony wiek”. Jak wynika z zebranych danych, kobiety i mężczyźni reprezentujący różne kategorie wiekowe wskazują na nieco inne powody dbania o zdrowie. O ile młodzi ludzie (bez względu na płeć) mają podobną świadomość znaczenia zasobu jakim jest zdrowie, a także wyrażają przekonanie o indywidualnej odpowiedzialności za własną kondycję psychofizyczną i częściowo podają podobne powody dbania o zdrowie (m.in. wskazują na znaczenie prowadzenia samodzielnego, niezależnego życia oraz możliwość aktywności w życiu rodzinnym i zawodowym), o tyle u starszych badanych różnice w omawianym aspekcie stają się bardziej wyraźne. Wskazując powody dbania o zdrowie, kobiety będące $\mathrm{w}$ średnim wieku podkreślały przede wszystkim, że dbają o ten zasób, aby być aktywnym w obszarze życia rodzinnego, natomiast mężczyźni w obszarze życia zawodowego oraz towarzyskiego. Różnice wystąpiły również między kobietami i mężczyznami reprezentującymi najstarszą kategorię wiekową. Starsze rozmówczynie troszczyły się o zdrowie, żeby ustrzec się chorób, nie sprawiać kłopotów innym, a także być ciągle aktywną - pomagać bliskim lub uczestniczyć w życiu towarzyskim. Ich rówieśnicy obawiali się zwłaszcza niedołężności 
i uzależnienia od innych oraz ponoszenia kosztów związanych z leczeniem.

Biorąc pod uwagę powyższe rozważania, płeć słabo różnicuje postawy wobec zdrowia młodych ludzi. Mamy tu do czynienia $\mathrm{z}$ androgynizacją w obszarze postaw wobec zdrowia, przede wszystkim w zakresie świadomość znaczenia zdrowia dla kapitału jednostki. Młodzi ludzie traktują zdrowie jako jego ważny zasób. Nieco inaczej wygląda aspekt behawioralny postawy wobec zdrowia $w$ tej kategorii wiekowej. Na zachowania zdrowotne młodych ludzi nadal wpływają patriarchalne wzorce kobiecości i męskości (aspekt ten zostanie omówiony w kolejnych podrozdziałach). Postawy wobec zdrowia osób w średnim wieku i starych są zdecydowanie silniej zróżnicowane ze względu na płeć. Wynika to z realizowania przez nie patriarchalnych wzorów kobiecości i męskości. O ile zdrowie stanowi bardzo waży zasób dla kobiet, o tyle wśród mężczyzn nie stanowi on takiej wartości, jak np. siła fizyczna, aktywność i możliwość pracy zawodowej (bez względu na stan zdrowia).

\title{
5.2. Komponent afektywny
}

\subsubsection{Ocena własnego zdrowia a płeć i wiek (Krystyna Dzwonkowska-Godula)}

\author{
Jak pisała M. Sokołowska:
}

Kryteria zdrowia są historyczne, zmieniają się wraz z sytuacją społeczną, warunkami środowiskowymi, z normami i zwyczajami określonych zbiorowości społecznych. Są też zależne od dążeń i wartości, jakie kierują życiem ludzi. $\mathrm{W}$ związku z tym ocena zdrowia i choroby zmienia się w zależności od jednostki, gdyż jest uwarunkowana bardzo indywidualnymi potrzebami subiektywnymi i reakcjami (Sokołowska 1980: 125-126).

Wyniki badań sondażowych pokazują, że między innymi płeć i wiek należą do zmiennych różnicujących zadowolenie z własnej kondycji psychofizycznej (CBOS 2012a). Kobiety stosunkowo częściej niż mężczyźni oceniają swój stan zdrowia jako zły (odpowiednio 16\% i 9\%). Tylko nieco połowa $\mathrm{z}$ nich (52\%) określa go jako dobry w porównaniu z 62\% męskiej zbiorowości badanych. Wynika to między innymi z faktu, że w populacji kobiet więcej jest osób starszych (w związku z większą umieralnością i krótszym życiem mężczyzn) i duża część z nich zmaga się z przewlekłymi 
chorobami (44\% w stosunku do $26 \%$ mężczyzn)7. Starzeniu się i związanym z nim pogarszaniu się kondycji psychofizycznej towarzyszy narzekanie na własne zdrowie, podczas gdy osoby młode deklarują powszechnie zadowolenie w tym względzie (CBOS 2012a).

Interesujące jest jednak nie tylko to, jak ludzie oceniają stan swojego zdrowia, ale dlaczego tak go oceniają, jakimi kryteriami się przy tym posługują. W realizowanym badaniu jakościowym pytano o to kobiety i mężczyzn w różnym wieku. We wszystkich grupach badanych jako czynnik decydujący o dobrej kondycji psychofizycznej wskazywano brak choroby, problemów zdrowotnych, dolegliwości, ale też radzenie sobie ze schorzeniami. A zatem cierpienie na jakąś chorobę nie wyklucza określenia siebie mianem zdrowego, jeśli schorzenie jest leczone, kontrolowane przez człowieka oraz nie utrudnia codziennego, normalnego funkcjonowania. $\mathrm{W}$ wypowiedziach respondentów obu płci w różnym wieku powtarzało się również odwołanie do samopoczucia jako podstawy autooceny stanu zdrowia, ale też poleganie na kryteriach medycznych - diagnozie lekarskiej, wynikach badań, przyjmowaniu leków - jako wyznacznikach „jakości” kondycji psychofizycznej. Powszechne, wskazywane w każdej grupie badanych, było również porównywanie własnego stanu zdrowia $\mathrm{z}$ "formą" innych osób $\mathrm{w}$ tym samym wieku bądź też $\mathrm{z}$ własną kondycją przed laty. Warto przy tym zauważyć, że te same czynniki były podstawą odmiennej oceny stanu zdrowia różnych respondentów, np. leczona choroba była dla niektórych podstawą do określania własnej zdrowotnej kondycji jako dobrej (choroba nie utrudniała życia i nie stanowiła zagrożenia, bo była pod kontrolą), w przypadku innych wpływała natomiast na obniżenie tej oceny (jeśli definiuje się zdrowie jako brak choroby, to jej istnienie nie pozwala na pozytywną ocenę kondycji psychofizycznej) (Łuczak 2015).

Analiza wypowiedzi respondentów pozwala dostrzec różnice, zarówno w ocenie zdrowia, jak i w podawanych jej uzasadnieniach przez kobiety i mężczyzn reprezentujących różne kategorie wiekowe. Przyjrzyjmy się najpierw, jak płeć różnicuje afektywny komponent postawy wobec własnego zdrowia.

Wyniki badania potwierdziły stosunkowo lepsze oceny własnej kondycji psychofizycznej mężczyzn w porównaniu z kobietami. W grupie młodych respondentów wszyscy uczestniczący w badaniu mężczyźni ocenili ją pozytywnie (mimo jednoczesnego wskazywania różnego rodzaju dolegliwości), podczas gdy wśród młodych rozmówczyń były

7 Te różnice w deklaracjach mogą wynikać częściowo z braku świadomości takich schorzeń u mężczyzn, którzy rzadziej poddają się badaniom profilaktycznym i unikają lekarzy. 
osoby określające swój stan zdrowia jako średni czy przeciętny. Przy tym zadowolenie mężczyzn ze stanu swojego organizmu rzadko oznaczało jednoznaczną bardzo dobrą ocenę, towarzyszyły mu zastrzeżenia typu: „na razie dobry”, „w miarę dobry”, „całkiem nieźle”, „nie jest najgorzej”, „jest ok, ale się pogarsza”. Wśród badanych w średnim wieku nie było mężczyzn, którzy negatywnie ocenili swoje zdrowie (dominowały oceny pozytywne wobec kilku „średnich”), takie stanowiska natomiast pojawiły się wśród uczestniczek badania w tej kategorii wiekowej. Różnic tego typu w ocenie własnej kondycji psychofizycznej nie było w najstarszej kategorii badanych: w grupie przedstawicieli obu płci znalazły się osoby określające swoje zdrowie jako dobre, średnie oraz złe (podobieństwo autooceny zdrowia starych ludzi zaobserwowali także inni badacze - por. np. Tobiasz-Adamczyk 2000: 61).

Różnice między kobietami i mężczyznami w ocenie własnego stanu zdrowia wyjaśnić można socjalizacją płciową i kulturowymi koncepcjami kobiecości i męskości. Bardziej krytyczna w przypadku kobiet autoocena kondycji psychofizycznej może wiązać się z ich większą otwartością w mówieniu o różnego rodzaju odczuwanych dolegliwościach, co z kolei wynika $\mathrm{z}$ „wyższej społecznej akceptacji faktu chorowania przez kobiety” (Tobiasz-Adamczyk 2000: 61). Jako przedstawicielkom „słabej płci” przyzwala im się na narzekanie na zdrowie, uczy się obserwacji własnego ciała i rozpoznawania dolegliwości (np. w okresie menstruacji) (Tobiasz-Adamczyk 2000: 61; Królikowska 2011: 390). Ponadto, w związku z opieką nad zdrowiem całej rodziny mają one większą wiedzę na temat chorób, towarzyszących im objawów oraz sposobów leczenia. $\mathrm{W}$ rezultacie kobiety szybciej niż mężczyźni reagują na symptomy choroby, nawet te „mało ważne”, oraz zwracają uwagę na odczuwany dyskomfort fizyczny, co może przekładać się na gorsze oceny własnego zdrowia (Tobiasz-Adamczyk 2000: 61). W przypadku mężczyzn skarżenie się na dolegliwości jest traktowane jako słabość i nie mieści się w kulturowym wizerunku silnego mężczyzny, którego zdrowie ,jest niekwestionowane, gdyż "mocna płeć» ma mieć je z definicji" (Malinowska 2011: 11). Większe niezadowolenie kobiet ze swego stanu zdrowia może również wynikać z ich obiektywnie gorszej kondycji psychofizycznej, czego dowodzą statystyki pokazujące częstsze występowanie poszczególnych chorób, dysfunkcji i zaburzeń psychicznych wśród kobiet w porównaniu z mężczyznami (Ostrowska 2006, 2012; Frąckowiak-Sochańska 2011; Renzetti, Curran 2005: 525).

Uzasadniając autooceny stanu zdrowia, respondentki dokładniej niż uczestniczący w badaniu mężczyźni opisywały dotykające ich schorzenia i odczuwane dolegliwości, co świadczy o ich większej świadomości zdrowotnej. Potwierdzają to obserwacje innych badaczy. Jak zauważyła B. Tobiasz-Adamczyk: 
Sposób opisywania zdrowia i choroby jest odmienny u mężczyzn i kobiet. Zaobserwowano, że kobiety używają innych określeń niż mężczyźni dla opisania tych samych stanów chorobowych, podają więcej szczegółowych objawów, a dodatkowo informują o swojej chorobie poprzez pryzmat emocji towarzyszących zmianom chorobowym, tzn. opis objawów chorobowych obejmuje zarówno fizyczny, jak i psychiczny kontekst choroby (Tobiasz-Adamczyk 2000: 61).

Uczestniczki badania zwracały uwagę na złożoność i trudność określenia stanu zdrowia, wskazując np. na obiektywny i subiektywny wymiar takiej oceny. Niektóre z nich dopytywały, do czego konkretnie mają się odnieść w autoocenie zdrowia: „Jaka jest skala? W jaki sposób mam określić? Jakie są kryteria oceny?” (KM_11_34); „Ale w jakichś kategoriach?” (KM_12_34). Część rozmówczyń formułowała ambiwalentne oceny własnej kondycji psychofizycznej, dostrzegając rozbieżność między obiektywnymi wskaźnikami zdrowia a własnym samopoczuciem:

[...] obawiałam, że jest niedobrze, [...] no ale zrobiłam badania i wyszły nawet spoko, no więc mój stan zdrowia na ten moment okazuje się nawet dobry" (KM_5_28). [...] nie czuję się chora, natomiast wiem, że jestem chora [...]. To są problemy związane z chorobą jelit. [...] badałam się, miałam stwierdzoną chorobę i miałam operację. (Teraz czuję się - przyp. aut.) dobrze. Nieadekwatnie do tego, co mówią lekarze (KM_14_35).

Według jednej z respondentek porównanie swojej kondycji psychofizycznej z innymi wpływa na zmianę autooceny stanu zdrowia: „Subiektywnie oceniłabym go kiepsko, natomiast porównując się do swoich znajomych w tym samym przedziale wiekowym, to nie jest źle" (KSR_7_49). Pojawiły się także uwagi, że ocena ta jest zmienna i względna: „Zależy od dnia, nieraz jest tak, że bardzo dobrze, no ale w tej chwili to psychicznie to jest taki zlepek różnych rzeczy niezależnych ode mnie" (KSR_13_61). Badane zwracały uwagę na konieczność uwzględnienia zarówno zdrowia fizycznego, jak i psychicznego w ocenie kondycji swojego organizmu: „Jeżeli chodzi o zdrowie fizyczne, to czuję się bardzo dobrze, mam kondycję, w miarę [...]. Natomiast zdecydowanie gorzej jest z moim zdrowiem psychicznym" (KST_5_67).

Takie ambiwalentne autooceny zdrowia pojawiły się także u uczestniczących w badaniu mężczyzn, ale jedynie tych w średnim wieku. Można odnieść wrażenie, że mimo wyraźnych wskaźników ich złego stanu zdrowia (o których mówili), bronili się oni przed jednoznacznie negatywną oceną, co może wynikać z kulturowej koncepcji męskości, nieprzyzwalającej mężczyznom na narzekanie na zdrowie i chorowanie traktowane jako wyraz słabości: 
Można powiedzieć tak, że jestem bardzo zdrowy i jednocześnie bardzo chory. Mój układ ruchowy odmawia mi posłuszeństwa, dotyczy to stawów, stan kolanowy, stan biodrowy, które mi uprzykrzają życie totalnie, ograniczają mnie (MSR_11_57). Chyba lepiej (oceniam swój stan zdrowia - przyp. aut.) niż jest naprawdę. Tak, że oceniam dobrze, a myślę, że nie jest tak dobrze (MSR_12_58).

Badani zdawali się szukać argumentów, że „nie jest jeszcze z nimi aż tak źle”: „No moje zdrowie bym ocenił na zasadzie takiej, że [...] jest ono słabe, ale pozwala mi na realizację mojego życia, tak jak chcę” (MSR_15_61).

Analizując wypowiedzi pytanych mężczyzn, zauważono, że potrzebowali oni konkretnych kryteriów czy miar, żeby móc wypowiedzieć się na temat stanu własnego zdrowia, co można wiązać z męską racjonalnością. Niektórzy z nich stosowali skale do oceny swojej kondycji psychofizycznej: „W skali od jednego do dziesięciu osiem” (MM_13_32); "Ja jestem w tej chwili już blisko jedynki (w skali 1-5 - przyp. aut.). Optymistycznie chciałbym powiedzieć, że dwójka, ale to pewnie jest jedynka” (MSR_11_57); „Swój stan zdrowia oceniam [...] na trójkę” (MST_14_82). Inni posługiwali się „profesjonalnymi” wskaźnikami: „Tu się pochwalę, mam 46 lat, robiłem skład masy ciała i mam 16\% tkanki tłuszczowej, 79 kg mięśni i wiek biologiczny 28 lat” (MSR_5_46).

Jak pokazały wyniki badania poznawczego komponentu postaw wobec zdrowia, wypowiadający się mężczyźni traktowali sprawność fizyczną jako definicyjną cechę zdrowia. Także pytani o ocenę stanu własnej kondycji psychofizycznej odwoływali się do sprawności i wydolności organizmu. Możliwość bycia aktywnym fizycznie, uprawiania sportu była dla nich kryterium dobrego stanu zdrowia, natomiast kontuzje i ograniczenia ruchowe wskazywały na jego pogorszenie:

Jestem w pełni sprawny i wydaje mi się, że mój organizm jest dostatecznie wydolny, wysportowany, i też dobrze się czuję z tym (MM_3_22). Nie mam żadnych problemów w sensie wydolności, możliwości (MSR_14_61). Stąd wnioskuję, że raczej moje ciało jest na tyle zdrowe, skoro mogę uprawiać sport, to jest ok (MSR_4_40). Obecnie mam tylko jedną kontuzję, która powoduje, że nie mogę regularnie uprawiać sportu (MM_15_37).

Niektórzy badani wymieniali konkretne rodzaje sportów czy ruchowej aktywności:

Jeżdżę, uprawiam aktywnie sporty, jeżdżę na rowerze, biegam, przynajmniej kilka razy w roku wyjeżdżam w góry, nie tylko po to, by pochodzić po Krupówkach, tylko żeby pochodzić po szczytach, po szlakach. Wyjeżdżam w góry po to, by popływać pontonem po rzekach, uprawiam rafting tak zwany (MSR_2_39). Powiedzmy przebiegnę i nie narzekam, że muszę za chwilę 
odpocząć [...]. Trochę popływam, tak, że nie jest najgorzej ze sprawnością fizyczną (MSR_7_49).

Wypowiedzi te potwierdzają znaczenie sportu, siły i kondycji fizycznej dla męskości. Uczestniczki badania nie odwoływały się do tych aspektów w ocenie własnego zdrowia.

Mimo pewnych podobieństw autoocen zdrowia w grupie wypowiadających się kobiet oraz w grupie biorących udział w badaniu mężczyzn, wiek różnicował zarówno zadowolenie z własnej kondycji psychofizycznej, jak i podawane uzasadnienia dokonywanej oceny. Wśród młodych respondentek nie było osób negatywnie oceniających swoje zdrowie. Tym, co wyróżniało je na tle starszych uczestniczek badania, było traktowanie dbania o zdrowie jako jego „miary”. A zatem o dobrym stanie psychofizycznej kondycji świadczy, w przekonaniu badanych, zdrowy styl życia - regularne badania profilaktyczne, aktywność fizyczna, odpowiednie odżywianie:

(Oceniam swój stan zdrowia na - przyp. aut.) dobry. Dobry plus. Że raczej kontroluję się, tzn. regularnie badania krwi, cytologię. I raczej ostatnio, jeżeli coś mnie zaniepokoi, to raczej kontroluję. Dbam o zdrowie (KM_15_35). Prowadzę taki aktywny tryb życia, który się przekłada na zdrowie, jestem aktywna, nie mam jakichś nałogów, w zasadzie żadnych nie mam nałogów, więc [...] no głównie aktywność, to jest dużo, [...] i w miarę dobra dieta (KM_10_30).

Z kolei zaniedbywanie zdrowia i antyzdrowotne zachowania były wskazywane przez młode respondentki jako podstawa obniżenia autooceny kondycji psychofizycznej „(Swój stan zdrowia oceniam jako - przyp. aut.) nie bardzo dobry, a dobry dlatego, że cały czas palę papierosy” (KM_9_30). Jak stwierdziła jedna z badanych, określająca stan swojego zdrowia jako „średni”: „Tak oceniam swoje zdrowie, bo czuję, że nie dbam o siebie tak jak powinnam i ciągle coś mnie boli” (KM_13_34). Młode uczestniczki badania wyrażały tym samym przekonanie, że to one ponoszą odpowiedzialność za swoje samopoczucie i funkcjonowanie organizmu. Tendencję tę, dotyczącą młodych respondentów (i kobiet, i mężczyzn) zauważono już, omawiając wyniki badania dotyczące poznawczego komponentu postaw wobec zdrowia (sposobu pojmowania zdrowia oraz przekonań na temat wpływających na nie czynników). Dostrzec tu można wpływ promocji zdrowia i edukacji zdrowotnej podkreślających „dominującą rolę jednostki w osiąganiu zdrowia”, a w rezultacie obarczających ją odpowiedzialnością za swoje zdrowie (Borowiec, Lignowska, Makowska 2009: 170). Młodzi respondenci, a przynajmniej część z nich, w swoich wypowiedziach dawała wyraz przekonaniu, że „zdrowie można osiągnąć przez wysiłek i samodyscyplinę, z koncentracją na doskonaleniu i chronieniu ciała, 
kształtowaniu jego masy i rozmiarów” (Crawford 1980, za: Lizak, Seń, Kochman 2014: 150).

Co ciekawe, uczestniczki badania, mimo swojej metrykalnej młodości, w którą wpisane jest niejako zdrowie i witalność, odwoływały się, podobnie jak starsze respondentki, do swojego wieku, podkreślając, że „dobrze się trzymają”, w porównaniu z innymi bądź przeciwnie, obserwując pogorszenie swojej kondycji psychofizycznej:

[...] sądzę, że tak to całkiem w porządku jak na mój wiek [...]. Znaczy moi znajomi, ale to głównie przez to, że palą, oni mają już np. problemy z płucami i to dość sporo osób ma problemy z płucami, jakieś torbiele dziwne im się porobiły, więc uważam że w mojej grupie znajomych trzymam się całkiem w porządku (KM_3_24). Mój stan zdrowia jest średni, zawsze gdzieś, coś dolega, strzyka i łamie w krzyżu. No człowiek już się trochę sypie (KM_13_34).

Uczestniczki badania w średnim wieku, co w ich przypadku wydaje się bardziej naturalne, zauważały wpływ starzenia się na kondycję psychofizyczną. Jednak dotyczyło to respondentek mających więcej niż pięćdziesiąt lat. Porównywały one swój obecny stan zdrowia do stanu wcześniejszego, zauważając spadek siły i sprawności czy pojawienie się pewnych schorzeń:

Starzeję się, [...] głos mi siada [...]. Coraz trudniej jest ze zdrowiem (KSR_8_53). [...] już nie jestem taka sprawna jak kiedyś [...]. Czyli już nie ma siły. Już człowiek przyjdzie ze sklepu, to już się zmęczę. Już usiądę i odpoczywam godzinę, co kiedyś tego nie robiłam, a teraz muszę odpocząć [...]. No nie chce mi się różnych rzeczy robić. Może mogłabym jeszcze coś zrobić więcej i ta choroba zabiera mi tę siłę. To już życie się kończy i się nie chce robić (KSR_15_62).

Charakterystyczne dla badanych z tej grupy wiekowej (nie tylko pięćdziesiąt plus) było zwrócenie uwagi na problemy z kręgosłupem czy ogólniej układem kostno-stawowym oraz zaburzenia snu: „Bolą mnie kości, kolana, biodra, ciśnienie, nie można spać” (KSR_15_62); „[...] czasami mam problem z plecami, to faktycznie bolą mnie plecy, to tak, to mnie bolą” (KSR_2_41); „Jak na przykład w nocy nie śpię albo kumulują się tematy, o których myślę, budzę się o godzinie czwartej rano i już bym zaczynała dzień” (KSR_13_61). Można odnieść wrażenie, że respondentki niejako spodziewały się pogorszenia zdrowia w związku z wiekiem i niektóre z nich wyrażały zdziwienie swoją dobrą kondycją zdrowotną:

Nie mam problemów z ciśnieniem, śpię w nocy, zasypiam, wstaję (KSR_1_38). To znaczy wszystko jest dobrze, czuję się rewelacyjnie, zastanawiam się czy jeszcze żyję, bo nic mnie boli. I coraz częściej myślę o tym, żeby zrobić jakieś badania, żeby zobaczyć, czy wszystko jest ok. [...] wydaje się że jestem zdrowa, 
aczkolwiek pewnie tak nie jest (KSR_9_54). Nic mnie nie boli, mam dobre samopoczucie, no to chyba (mój stan zdrowia - przyp. aut.) jest dobry, nie? [...] zdaję se sprawę, że coś tam w końcu [...] przyjdzie, no bo jak samochód jeździ i w którymś momencie, no niestety zużywa się część i to na pewno (KSR_14_53).

W ostatniej cytowanej wypowiedzi zwraca uwagę porównanie organizmu do samochodu, które pojawiało się także w grupie mężczyzn. Badane w autoocenach zdrowia porównywały się nie tylko ze swoimi rówieśnikami, ale także z młodszymi od siebie osobami: „Wiem, że ludzie młodsi mają dużo poważniejsze problemy zdrowotne niż ja” (KSR_6_48); „Generalnie należę do osób, którym nie dolega nic poważnego [...]. Bo niektórzy już mają tam nadciśnienie w tym wieku, tam niejeden już, takie mają różne schorzenia, a ja no nie mam i, odpukać, nie chcę mieć" (KSR_14_53).

Charakterystyczne dla starych respondentek było pogodzenie się z „normalnymi” w ich przekonaniu dolegliwościami, schorzeniami, ograniczeniami w funkcjonowaniu organizmu, przyzwyczajenie do nich. Badane, kontrolując stan zdrowia, stosując się do zaleceń lekarzy dotyczących przyjmowania lekarstw oraz trybu życia, miały poczucie radzenia sobie ze zdrowotnymi problemami, co pozwalało im na pozytywną ocenę kondycji psychofizycznej:

Mam dolegliwości, które są przynależne każdemu człowiekowi. Dokucza mi czasami jedno, czasami drugie, ale to jest wszystko do ogarnięcia (KST_7_70). (Oceniam swój stan zdrowia - przyp. aut.) jako niezły, bo tak: ciśnienie mam opanowane, od kilku lat mam opanowane [...]. Biorę leki, wspomagane też na serce (KST_14_86). [...] mam trochę słuch przytępiony w jednym uchu. [...] to przeszkadza, bo to tak buczy, buczy, ale to się tak przyzwyczaiłam tyle lat. [...] trzeba z tym żyć (KST_10_71).

Dlatego, jak zauważyła jedna z nich: „Ja nie robię z igły widły [...]. Mam te leki i używam” (KST_14_86). Respondentki wyrażały przekonanie, że muszą doceniać zdrowie, jakie mają, bo mogłoby być gorzej. Zaznaczały, że „nie mają prawa narzekać”, bo „jak na swój wiek, to nie jest źle”, „mogłoby być lepiej, ale gorzej też”. One także porównywały się z innymi, wskazując jako pewne osiągnięcie nie tylko nie najgorszą kondycję psychofizyczną, ale sam fakt, że jeszcze żyją: „[...] tak się składa, że ciągle chodzę na pogrzeby ludzi z mojej półki” (KST_16_89). Ze względu na liczbę oraz różnorodność schorzeń, w tym tych związanych $\mathrm{z}$ wiekiem, a także stosunkowo dobrze zdiagnozowany stan zdrowia w związku z regularnymi wizytami u lekarza, w wypowiedziach starych uczestniczek badania pojawiało się najwięcej szczegółów „medycznych”: nazw chorób czy rodzajów przyjmowanych leków: „Kłopoty zdrowotne, 
takie z przewodem moczowym, kamienie nerkowe. Zaćma, osteoporoza, zaczynają się kolana, stawy [...]. No to, to że w szpitalu byłam, badania robiłam w kierunku tych nerek, kamieni. U okulisty byłam" (KST_1_64). Badane zwracały uwage przede wszystkim na problemy ze zdrowiem fizycznym, powodujące dyskomfort i utrudniające normalne funkcjonowanie. Samodzielność i radzenie sobie z codziennymi obowiązkami oraz możliwość pozadomowej aktywności była w tej grupie wiekowej respondentek wskazywana jako istotne kryterium oceny kondycji psychofizycznej:

No, zdrowie, które mam, które mi pozwala w miarę normalnie funkcjonować samodzielnie, chociaż, jak już wspomniałam, nie jest ono całkiem dobre, ale dopóki jestem samodzielna i mogę brać udział w jakimś życiu takim zewnętrznym, no to jestem zadowolona z tego" (KST_9_71). [...] jest bardzo dużo osób, które gorzej się czują i zapadły na takie postępujące choroby i gorzej już chodzą albo w ogóle już nie wychodzą (KST_16_89).

Tylko w tej grupie wiekowej kobiet znalazła się respondentka podkreślająca znaczenie zdrowia psychicznego, które w jej przekonaniu jest bagatelizowane. Na własnym przykładzie pokazywała ona, że sprawność i dobre funkcjonowanie organizmu nie musi iść w parze $\mathrm{z}$ dobrą kondycją psychiczną.

W badanej zbiorowości mężczyzn młodzi rozmówcy wyróżniali się pozytywnymi ocenami swojego zdrowia, co można wyjaśniać ich wiekiem i związaną z nim prawdopodobnie dobrą kondycją psychofizyczną. Analiza ich wypowiedzi wskazuje, że część $\mathrm{z}$ nich zmagała się z różnego rodzaju dolegliwościami, jednak nie wpływały one na ich ogólną pozytywną autoocenę zdrowia. Zwraca uwagę fakt posługiwania się przez część badanych „fachowymi” nazwami schorzeń czy rodzajów badań, mimo że, jak już zauważono, to kobiety cechuje większa świadomość zdrowotna i medyczna wiedza. Jak wynika $z$ ich wypowiedzi, respondenci doświadczający jakichś problemów ze zdrowiem, pozostają pod kontrolą lekarza bądź poszukują informacji medycznych na własną rękę i są kompetentni w ocenie własnej kondycji psychofizycznej: „Mam podwyższony cholesterol, a reszta rzeczy w normie. [...] ponieważ mam alergię, wzrok mi w ciągu roku pojechał o pół dioptrii, ale jeszcze nie noszę okularów. [...] wycięto mi wyrostek robaczkowy” (MM_5_26); „Miałem problemy troszeczkę, okazało się, że niedużą mam niedoczynność tarczycy, w związku z czym też się leczę" (MM_10_31). Ponieważ miarą zdrowia jest dla nich sprawność fizyczna, jako problem zdrowotny wskazywali oni kontuzje, uniemożliwiające czy też ograniczające uprawianie sportu bądź wspominali o otyłości, również wpływającej na aktywność ruchową, ale także na wygląd, do którego młodzi mężczyźni przywiązywali dużą wagę. 
Młodzi respondenci zaznaczali, że $\mathrm{w}$ autoocenie kondycji zdrowotnej opierają się głównie na własnych subiektywnych odczuciach: „Uważam, że z moim zdrowiem jest dobrze” (MM_10_31); „Wydaje mi się, że jestem osobą zdrową” (MM_4_24); „No, myślę, że (moje zdrowie - przyp. aut.) jest [...] dobre” (MM_1_21); „Ogólnie uważam, że nie jest najgorzej, tak? Nigdy nie narzekałem na jakieś poważniejsze choroby, nie doświadczyłem jakiś większych kłopotów zdrowotnych" (MM_7_28). Niektórzy z nich wyrażali zdziwienie, że ich subiektywne oceny znajdują potwierdzenie $\mathrm{w}$ dobrych wynikach badań lekarskich, inni potrzebowali takich obiektywnych wskaźników, by móc określić stan własnego zdrowia: „(Mój stan zdrowia jest - przyp. aut.) dobry, bardzo dobry. Nawet na podstawie badań jak robiłem wszystkie wyniki były ok” (MM_12_32); „(Oceniam swój stan zdrowia jako dobry - przyp. aut.) na podstawie samopoczucia własnego i potwierdzenia tego w badaniach" (MM_14_35).

Tym, co wyróżniało młodych uczestników badania w grupie wypowiadających się mężczyzn, było traktowanie dbania o zdrowie jako podstawy jego oceny. Respondenci przyjmowali zatem, że o dobrym zdrowiu świadczy podejmowanie prozdrowotnych działań, takich jak stosowanie się do zaleceń lekarskich, kontrola stanu zdrowia, zmiana sposobu odżywiania, czy aktywność fizyczna:

Myślę, że (mój stan zdrowia jest - przyp. aut.) dobry, staram się w miarę możliwości dbać o swoje zdrowie, co jakiś czas robić badania profilaktyczne. Oczywiście z wiekiem na inne rzeczy zwraca się uwagę, bardziej na to, co się powinno jeść, na poziom cholesterolu, cukrów, na inne trochę rzeczy [...] (MM_14_35). Rzadko choruję, staram się dbać jakoś [...]. Staram się dbać o kondycję fizyczną, żeby to jakoś wyglądało (MM_9_3o). Dobre pytanie, bo rok temu miałem problem $\mathrm{z}$ ciśnieniem troszkę, ale zmieniłem trochę dietę, zacząłem jeść gorzką czekoladę i pić dużo niegazowanej wody i mi przeszło, czyli tak no stan jest dobry, nie jest bardzo dobry, jest dobry (MM_2_22).

Jak już zauważono, takie poczucie indywidualnej odpowiedzialności za własne zdrowie wyrażały, w odpowiedzi na pytanie o kryteria oceny swej kondycji psychofizycznej, także młode kobiety uczestniczące w badaniu.

Porównując wypowiedzi młodych respondentów i badanych w średnim wieku, można odnieść wrażenie, że ci drudzy lepiej oceniali swoje zdrowie. Gdy młodzi stosowali określenie „dobry” do opisu własnego stanu zdrowia, zastrzegając, że nie jest ono idealne czy też, że jest to ich osobiste przekonanie, uczestnicy badania w średnim wieku stosunkowo częściej oceniali swoją kondycję jako bardzo dobrą, nie mając żadnych zastrzeżeń: 
Myślę, że mój stan zdrowia jest dobry z naciskiem na bardzo dobry (MSR_1_38). Bardzo dobrze (oceniam swój stan zdrowia - przyp. aut.) (MSR_9_54). Nie choruję. Zdrowy jestem (MSR_13_6o). Sprawny, mobilny (MSR_2_39). Nie mam żadnych problemów w sensie wydolności, możliwości. Życzyłbym wielu osobom, żeby miały taką wydolność, takie możliwości (MSR_14_61).

Jak można zauważyć w powyższych wypowiedziach, dla części z nich podstawowym kryterium zdrowia była fizyczna sprawność organizmu. Niektórzy z rozmówców wyrażali dumę z własnej kondycji psychofizycznej, podkreślając, że „nigdy” czy „w ogóle” nie chorowali, nie cierpią na żadne przewlekłe choroby: „Nie pamiętam kiedy ostatni raz byłem u lekarza” (MSR_9_54). Istotne dla nich było porównanie z młodszymi od siebie osobami: „Widzę swoich rówieśników i młodszych ludzi, którzy się gorzej czują ode mnie. Kręgosłupy ich bolą, nogi ich bolą, a ja jakoś sobie chodzę i jakoś bardzo mnie nic nie boli, mimo że mam swoje 47 lat" (MSR_6_47). Przy czym trzeba zauważyć, że niektórzy z badanych nie wymagali zbyt wiele od własnego organizmu, by móc pozytywnie ocenić swoje zdrowie: "Jeszcze żyję w pozytywnym sensie tego znaczenia. Nie narzekam na takie wielkie problemy [...]. Co mam odpowiedzieć? Mam dwie nogi, mam dwie ręce, że nie wymiotuję, że nie boli mnie głowa, całokształt” (MSR_10_56).

Można odnieść wrażenie, że część respondentów w średnim wieku miała potrzebę podkreślenia, udowodnienia własnej witalności i dobrej kondycji fizycznej „mimo wieku”. Mógł to być wyraz tęsknoty za młodością lub też przejaw trudności pogodzenia się z upływem czasu, próby zatrzymania go (Chmura-Rutkowska, Ostrouch 2007: 69). Świadczyć może o tym wypowiedź jednego z badanych, chwalącego się w wywiadzie dobrymi wskaźnikami stanu własnego organizmu, w tym jego biologicznego wieku (ocenianego na 28 lat przy metrykalnym wieku 46 lat): „I przyznam się szczerze, że to mi sprawia największą frajdę, bo pewnej młodości nie da się zachować, no ale tym się można pochwalić i ja tak też mentalnie się czuję jako trzydziestolatek, a nie jako czterdziestopięciolatek” (MSR_5_46). Respondenci podkreślali konieczność podtrzymywania dobrej formy własnego ciała głównie poprzez aktywność ruchową. Przy czym uprawianie sportu, w tym także sportów ekstremalnych, było samo w sobie dla niektórych z nich wyznacznikiem stanu zdrowia (utożsamianego ze sprawnością fizyczną).

Ci mężczyźni w tej grupie wiekowej badanych, którzy nieco gorzej, ale nadal pozytywnie oceniali swoje zdrowie, nie zawsze wyjaśniali skąd ta „obniżona” nieco ocena: „Uważam, że jest [...], całkiem nieźle. Bardzo dobrze, bardzo dobrze to może nie, ale całkiem nieźle” (MSR_4_40); „Powiem tak - no nie jest źle” (MSR_6_47); „Jak oceniam swój stan? Jako 
dobry, może nie jako bardzo dobry, ale jako dobry" (MSR_8_53). Nie byli oni zatem tak szczerzy i otwarci w mówieniu o swoich schorzeniach czy dolegliwościach, jak młodzi respondenci. Być może świadczy to o tym, że dla młodego pokolenia mężczyzn przyznanie się do dysfunkcji własnego organizmu nie jest już oznaką słabości i „niemęskości”. Z drugiej strony wśród badanych w średnim wieku znalazł się respondent opowiadający o swoich zdrowotnych problemach natury psychicznej: „Myślę, że mam problemy na tle nerwowym. Nie cierpię na żadne choroby przewlekłe, natomiast często nie panuję nad swoimi emocjami. Też chodzę na terapię z tym związaną. [...] bardziej mam problemy egzystencjalne. [...] one wpływają na moje zdrowie, bo zastanawiam się nad sensem życia i za bardzo go nie widzę" (MSR_3_40). Jednak jako czterdziestolatek należał on do młodszych osób w tej kategorii wiekowej, pokoleniowo bliżej mu było do trzydziestolatka niż sześćdziesięciolatka, stąd może ten niemieszczący się w patriarchalnej koncepcji męskości stosunek do własnego zdrowia.

Przypomnijmy, że to w grupie mężczyzn w średnim wieku, biorących udział w badaniu, znaleźli się rozmówcy formułujący ambiwalentne autooceny kondycji psychofizycznej, co wyróżniało ich na tle pozostałych mężczyzn. Przy czym problemem dla badanych były ograniczenia sprawności ruchowej, uniemożliwiające normalne funkcjonowanie i wykluczające ich z pewnych aktywności „Ja byłem człowiekiem dość żywotnym, lubiłem grać w piłkę, lubiłem biegać, lubiłem chodzić, chodzić, a teraz [...] unikam tego, unikam tego, pewne rzeczy w ogóle są niedostępne dla mnie, jak gra w piłkę, jak jakieś tam uprawianie sportu. To w ogóle jest dla mnie niedostępne, ale jest problem $\mathrm{z}$ chodzeniem [...]. To jest lipa” (MSR_11_57). Jeden z nich, mający po wypadku trwale uszkodzoną rękę oraz problem z chodzeniem, określił się mianem „inwalidy”, pokazując na własnym przykładzie siłę determinacji i woli w pokonywaniu takich zdrowotnych problemów: „[...] staram się nie pieścić, staram się chodzić, [...] i to mi pomaga, bo wtedy to się zapomina o tych chorobach i ta rehabilitacja tu postępuje [...]. Ale, ale tak jak mówię chyba najbardziej zawdzięczam to sobie, że staram się, [...] z tym, co mam, z tymi możliwościami moimi fizycznymi robić to, co mogę robić" (MSR_15_61). Zauważył on genderowe uwarunkowanie takiej postawy, podkreślając, że „ze względu na wrodzony optymizm i umiejętność radzenia sobie $\mathrm{z}$ dolegliwościami mężczyzna jest w stanie »żyć jak chce»" (MSR_15_61). $\mathrm{W}$ przekonaniu badanego przedstawiciele jego płci nie poddają się chorobie, nie pozwalają, by cokolwiek przeszkodziło im w realizacji celów. Mamy tu odwołanie do takich stereotypowo przypisywanych mężczyźnie cech jak: aktywność, autonomiczność, niezależność czy wiara w siebie (Lisowska 2008: 76-77). 
Również starzy respondenci starali się robić dobrą minę do złej gry, tj. zapewniali, że mimo problemów zdrowotnych z ich zdrowiem „nie jest najgorzej” i starali się nie narzekać. Próbę wycofania się z jednoznacznie negatywnej oceny własnego zdrowia zaobserwować można było w jednym z wywiadów, w którym badany tak określił stan swojej psychofizycznej kondycji: „Ja to sądzę, że źle. Ani nie bardzo źle, ani nie bardzo dobrze, tylko źle. Tak, no tak średnio” (MST_13_77). Dla niektórych kryterium zdrowia było uniknięcie w ciągu swojego życia pobytu w szpitalu i operacji, co traktowali jako sukces. Badani porównywali swoją kondycję psychofizyczną do stanu własnego organizmu przed laty bądź do młodszych osób: „Ja na ten moment oceniam pozytywnie, pomimo, po tych sześciu zawałach, ale ja widzę naprawdę młodych ludzi, którzy zdrowie mają gorzej niż osiemdziesięciolatki. I to mnie przeraża” (MST_7_67). Przy czym zauważono, że to cechowało mężczyzn niezależnie od wieku, to fakt, że zdrowie utożsamiali oni często z fizyczną sprawnością. Zdolność do określonego wysiłku i ruchowej aktywności była dla nich miarą jakości tego ich zasobu: „Wiadomo, człowiek nie jest sprawny, kiedyś potrafiłem zrobić ileś tam pompek, podciągnąć się, dwadzieścia czy ileś razy na drążku, teraz jakby się udało dziesięć, to bym się cieszył” (MST_11_71). Jednak w uzasadnieniach autoocen zdrowia starych uczestników badania pojawiły się także uwagi na temat pogarszania się sprawności umysłowej - kłopotów z pamięcią, czy działania zmysłów: „I wzrok, już nie mówiąc o słuchu. Skleroza, pamięć - pamięta się to co było pięćdziesiąt lat, a nie pamięta się co było dzień czy godzinę temu się nieraz zapomina” (MST_13_77). Tym, co wyróżniało respondentów z tej kategorii wiekowej było wskazywanie na znaczenie wieku dla ich kondycji psychofizycznej: „Nie narzekam. Można to tak w skrócie powiedzieć. Aczkolwiek wiadomo, że z wiekiem to i wzrok i jakieś tam sprawy krążeniowe siadają (MST_11_71); „Nie jest tak najgorzej, ale to, niestety, już nie to zdrowie, co kiedyś” (MST_2_63). Badani nie odwoływali się natomiast do kryteriów medycznych - nie wspominali o przyjmowanych lekach czy zdiagnozowanych chorobach. W przeciwieństwie do rówieśniczek uczestniczących w badaniu, nie opisywali szczegółowo swoich problemów zdrowotnych, lakonicznie stwierdzając, że są chorzy bądź używając potocznych, eufemistycznych określeń: „[...] serce mi dokucza, idę troszkę szybciej, to strasznie mi wali” (MST_14_82). Posługiwali się porównaniami, specyficznymi „miarami” jakości zdrowia: „No, no ściachany (stan zdrowia - przyp. aut.), no tak jak ten, jak samochód po dwustu tysiącach przejazdów” (MST_3_63); „No nie jest dobrze. Mój stan zdrowia to jest jedna czwarta zdrowia” (MST_11_71). Można zatem odnieść wrażenie, że badani mówili o swoich schorzeniach i dolegliwościach niechętnie, co może wynikać z ich przekonania ukształtowanego w patriarchalnej 
socjalizacji, że mężczyźnie nie wypada narzekać na zdrowie, okazywać słabości.

Podsumowując, analiza wyników badania dotyczących afektywnego komponentu postaw wobec zdrowia, potwierdza zasadność postawienia hipotez dotyczących różnicującego wpływu płci i „upłciowionego wieku” na oceny stanu zdrowia. W grupie uczestników badania kobiety okazywały się być bardziej krytyczne od mężczyzn wobec stanu własnej kondycji psychofizycznej. Wypowiadający się mężczyźni rzadziej określali ją jako średnią czy złą, stosowali pozytywne określenia, mimo jednoczesnego wskazywania różnych odczuwanych dolegliwości bądź formułowali oceny ambiwalentne, jakby unikali narzekania na własne zdrowie, jako nieprzystającego męskości. Wpływ kulturowych koncepcji kobiecości i męskości można zauważyć w podawanych przez badanych kryteriach oceny stanu zdrowia. Uczestniczące w badaniu kobiety bardziej szczegółowo opisywały swoje problemy zdrowotne, odwołując się do medycznych określeń, co wynika $\mathrm{z}$ ich większego zainteresowania sprawami zdrowotnymi, kształtowanego w procesie socjalizacji. Charakterystyczne dla mężczyzn było traktowanie sprawności fizycznej i wydolności organizmu jako kryterium oceny własnej kondycji psychofizycznej, co można wiązać z kulturowym wizerunkiem męskości, w który wpisana jest fizyczna siła i sprawność. Z kolei ich potrzeba stosowania konkretnych miar (np. skal czy innych liczbowych wskaźników - np. liczby podciągnięć na drążku, które jest się stanie zrobić) dla określenia stanu zdrowia może być interpretowana jako wyraz męskiej racjonalności.

Potwierdzenie znalazła hipoteza o coraz gorszej ocenie własnego zdrowia wraz $\mathrm{z}$ wiekiem. Jednak jak zauważono, młodzi ludzie, choć $\mathrm{z}$ reguły wyrażali zadowolenie z własnej kondycji psychofizycznej, dostrzegali u siebie wiele różnych dolegliwości czy problemów zdrowotnych. W autoocenach zdrowia czynili zastrzeżenia, że ich stan zdrowia „jest dobry, ale nie bardzo dobry". Dotyczyło to także młodych mężczyzn, którzy wyróżniali się na tle starszych przedstawicieli swojej płci uczestniczących w badaniu brakiem oporów w mówieniu o słabościach swojego organizmu. Można tu zatem dostrzec pokoleniową zmianę w pojmowaniu męskości - młode osoby nie traktują już choroby jako czegoś, o czym mężczyźnie nie wypada mówić. Co więcej, w opisywaniu swoich dolegliwości posługiwali się oni fachowymi, medycznymi terminami, świadczącymi o ich zainteresowaniu zdrowiem i "medycznej” wiedzy. Wypowiadający się młodzi mężczyźni podobni byli do swoich rówieśniczek także w przekonaniu o indywidualnej odpowiedzialności za własne zdrowie, co można wiązać $\mathrm{z}$ ich pokoleniową socjalizacją $\mathrm{w}$ duchu ideologii healthismu, w czasach mody na zdrowy styl życia (Crawford 1980, za: Borowiec, Lignowska 2012; Szpunar 2009). A zatem można tu zauważyć słaby 
wpływ płci na sposób oceniania własnego zdrowia przez młodych uczestników badania.

W analizie komponentu afektywnego postaw wobec zdrowia badanych w średnim wieku i starych różnicujący wpływ płci jest bardziej zauważalny. W grupie respondentów w średnim wieku mężczyźni starali się podkreślać dobry czy nawet bardzo dobry stan swojego zdrowia, wskazując na utrzymywanie sprawności i kondycji organizmu mimo wieku. Wskazywać to może na ich przekonanie, że mężczyzna, zgodnie z patriarchalną koncepcją męskości, jest z definicji zdrowy i silny, a przynajmniej nie powinien narzekać na własne zdrowie, „pieścić się”, jak określił to jeden z badanych. Świadczy o tym także wyrażana przez nich duma, że „nigdy” czy „w ogóle” nie chorowali. Jeśli chodzi o starych respondentów, z których część nie mogła pozytywnie ocenić swojego zdrowia ze względu na odczuwane problemy zdrowotne, bardzo niechętnie, skrótowo i bez szczegółów wypowiadali się oni na temat swojej złej kondycji psychofizycznej. Ich obserwacje kontrastują z relacjami rówieśniczek, które dokładnie opisywały swoje schorzenia i dolegliwości, dowodząc troski o własne zdrowie oraz regularnego korzystania z opieki lekarskiej (wskazywały nazwy chorób, rodzaj przyjmowanych leków, badania, którym się poddają).

\subsection{Komponent behawioralny}

\subsubsection{Zachowania prozdrowotne a płeć i wiek (Emilia Garncarek)}

Zachowania zdrowotne definiowane są m.in. jako szeroko pojęte działania ukierunkowane na cele zdrowotne. Jeżeli wykazują one pozytywny wpływ na zdrowie, wtedy zwane są zachowaniami prozdrowotnymi, jeżeli natomiast prowadzą do powstania licznych zaburzeń w prawidłowym życiu człowieka, mówimy o zachowaniach antyzdrowotnych (Tobiasz-Adamczyk 200o). Badając postawy jednostek wobec zdrowia, postanowiono poznać nie tylko sposób myślenia ludzi o zdrowiu w powiązaniu z płcią i wiekiem, ale także ich zachowania wobec tego zasobu. W pierwszej kolejności zajmiemy się zachowaniami prozdrowotnymi.

Badacze zajmujący się problematyką zachowań zdrowotnych wskazują na różne formy aktywności celowej ukierunkowane na ochronę lub osiągnięcie poprawy zdrowia (Puchalski 1989). Beata Tobiasz-Adamczyk wyróżnia pięć klas zachowań prozdrowotnych, do których zalicza: unikanie 
używek, pozytywne praktyki zdrowotne (m.in. aktywność fizyczna, dbanie o higienę ciała, odpowiednia ilość snu), zwyczaje żywieniowe (m.in. zbilansowana dieta, unikanie podjadania pomiędzy posiłkami, przestrzeganie liczby posiłków w ciągu dnia, utrzymywanie określonej diety), bezpieczne prowadzenie samochodu; zachowania związane z działalnością prewencyjną/profilaktyką zdrowotną (m.in. regularne wizyty kontrolne u lekarzy, wykonywanie badań profilaktycznych, tj. cytologia, badanie piersi, jader, a także samokontrola organizmu) (Tobiasz -Adamczyk 2013: 27). Do ostatniej z klas, wymienionych przez autorkę, można dodać również stosowanie się do zaleceń lekarskich, co nie zawsze miało miejsce w przypadku naszych rozmówców, a na co będziemy wskazywać w dalszej części opracowania. Cytując model zachowań zdrowotnych Kasla i Cobba, Tobiasz-Adamczyk podkreśla, że autorzy przypisują znaczenie także samokontroli, która pozwala jednostce na uniknięcie czynników ryzyka (m.in. takich jak: nikotynizm, nadmierne spożywanie alkoholu, brak aktywności fizycznej czy też niewłaściwa dieta) (Kasl, Cobb 1966, za: Tobiasz-Adamczyk 2013: 26).

Realizując badanie, zapytaliśmy kobiety i mężczyzn, w jaki sposób dbają o swoje zdrowie, jakie działania prozdrowotne realizują. Większość działań sprzyjających zdrowiu podejmowanych przez rozmówczynie pokrywała się z działaniami, które podejmują mężczyźni, m.in. aktywność fizyczna, odpowiednie odżywianie się, wykonywanie badań profilaktycznych, dbanie o higienę. Ze szczegółowej analizy wypowiedzi, uwzględniającej płeć badanych, ich wiek oraz „upłciowiony wiek” wynika, że podobnie jak w przypadku poprzednich aspektów składających się na postawy wobec zdrowia także tutaj wystąpiły różnice między poszczególnymi kategoriami badanych. Część zachowań sprzyjających zdrowiu stanowiła dla niektórych kategorii płci i wieku rodzaj głównych działań prozdrowotnych i była wymieniana przez wszystkich badanych reprezentujących daną kategorię, natomiast część zachowań była wskazywana tylko przez nielicznych reprezentantów danej kategorii płci i wieku. Należy podkreślić, że te same działania prozdrowotne były również inaczej rozumiane przez poszczególnych respondentów/ki. W pierwszej kolejności zajmiemy się działaniami podejmowanymi na rzecz zdrowia przez kobiety (bez względu na wiek), następnie przez mężczyzn (również bez względu na wiek). W dalszej części opracowania zostaną przedstawione różnice w zachowaniach prozdrowotnych kobiet i mężczyzn reprezentujących poszczególne kategorie wiekowe, natomiast na zakończenie przyjrzymy się dbaniu o zdrowie w poszczególnych kategoriach wieku. Podejmowane przez naszych rozmówców/rozmówczynie działania prozdrowotne będą przedstawiane według częstotliwości ich występowania - od najczęściej wskazywanych, po te, które były wymienione przez nielicznych badanych/badane. 
Analiza zebranych danych pokazała, że większość rozmówczyń wskazywała na podejmowanie aktywności fizycznej jako ważnego działania prozdrowotnego. Kobiety deklarowały, że ćwiczą w domu lub w fitness clubach, uprawiają sport, dużo spacerują, starają się być w ruchu. Należy podkreślić, że kobiety wskazywały na nieco inne rodzaje aktywności fizycznej niż mężczyźni, którzy wzięli udział w badaniu. Badane wymieniały m.in.: pływanie, jazdę konną, jazdę na rowerze, ćwiczenia na siłowni, gimnastykę (również w domu), spacery, taniec bądź ćwiczenia oparte na elementach tańca, które wzmacniają jędrność ciała i jego elastyczność, ćwiczenia dla umysłu czy też uzyskania lepszego samopoczucia psychicznego:

Uwielbiam sport, uwielbiam pływać, jazdę konną [...]. Na rowerze jeżdżę ostatnio, lubię sobie pojechać, odpocząć, bardzo to robię świadomie, w miejsce, gdzie mogę się wyciszyć, nie myśleć o tym, co muszę, to jest dla mnie istotne. No pływanie, ale pływanie to jest dla mnie reset psychiczny, bo od zawsze trenowałam pływanie i to jest dla mnie zupełnie naturalna sprawa, że muszę iść popływać, poćwiczyć, że to jest taki dzień, tylko tego potrzebuję (KM_5_28).

Aktywność fizyczną podejmują przede wszystkim dla zachowania zdrowia bądź aby zniwelować problemy zdrowotne już istniejące, np.: basen przy problemach z kręgosłupem (KSR_3_42), zajęcia ruchowe/gimnastyczne przy siedzącej pracy (KSR_5_47), ćwiczenia w domu jako remedium na odczuwanie dolegliwości bólowych (KSR_7_49), tai chi dla większej sprawności i energii do życia odczuwanej po aktywności (KSR_8_53). Natomiast część kobiet wspomniała, że podejmuje aktywność fizyczną również na rzecz wyglądu - utrzymania zgrabnej sylwetki, bądź jej poprawy: „[...] chyba, że za bardzo przeforsuję się na rowerze, to wtedy tak, muszę wtedy sobie na trochę odpuścić. Ale tez wiem, że muszę to robić regularnie, żeby utrzymać formę i sylwetkę. [...] rower, aktywność fizyczna, trochę basen” (KSR_4_45). Jak zaznacza Sabina Królikowska, funkcjonujące w naszej kulturze stereotypy wyglądu kobiet i mężczyzn przejawiać się mogą np. „w preferowanych przez każdą z płci formach aktywności fizycznych, w sposobach odżywiania oraz w stosowaniu różnorodnych diet, a także w zaburzeniach odżywiania” (Królikowska 2011: 391). Ogólnopolskie badania pokazują, że preferowanymi formami aktywności fizycznej wśród mężczyzn są: jazda na rowerze, siatkówka, koszykówka, pływanie, piłka nożna, pływanie, tenis, sporty wodne oraz ćwiczenia na siłowni. Kobiety wybierają natomiast różne formy gimnastyki, takie jak np. aerobik, czy callanetics (CBOS 2013a). Kobiety zgodnie ze stereotypem wyglądu zewnętrznego częściej wolą ćwiczenia, które pozwolą im wymodelować i/lub wyszczuplić sylwetkę, natomiast 
mężczyźni mają potrzebę budowania masy mięśniowej, wytrzymałości, szybkości, zręczności. Podział na preferowane przez mężczyzn i kobiety formy aktywności fizycznej odzwierciedla stereotypowy podział na „silnego mężczyznę" i „słabą kobietę”. Postrzeganie ciała kobiet i mężczyzn wpisane jest wyraźnie w stereotypy płci (Królikowska 2011). Nasze rozmówczynie również preferowały aktywności, które w naszej kulturze przypisuje się kobietom, a dbanie o zdrowie łączyły z dbaniem o wygląd. Należy w tym miejscu dodać, że w nawiązaniu do aktywności fizycznej nieliczne kobiety wspomniały również, że korzystają z masaży, wizyt w SPA bądź rehabilitacji.

Kolejnym działaniem prozdrowotnym podejmowanym przez kobiety było odpowiednie odżywianie się, zamiennie nazywane „zdrowym odżywianiem się". Zwracały one uwagę na odpowiedni dobór spożywanych produktów, unikanie ciężkostrawnych potraw, lekką i nietłustą dietę, bogatą w warzywa i owoce, ograniczanie jedzenia fast foodów, unikanie lub ograniczanie chemicznych substancji w jedzeniu. Kobiety wspominały również o wartości naturalnego, zdrowego jedzenia: „Nie jem chemii prawie $\mathrm{w}$ ogóle. To znaczy nie używam ani do gotowania żadnych glutaminianów, ani jakiś przypraw gotowych miksów. Lubię sama gotować. [...] staram się zdrowo odżywiać. Co nie oznacza, że czasami nie skuszę się na coś. Ale żyje się raz" (KM_8_29). Badane zaznaczały, że starają się ograniczać słodycze i spożywać jak najmniej przetworzone jedzenie. Niektóre z nich podkreślały wartość „domowego jedzenia”, regularność posiłków, a także jedzenia odpowiednich, nie za dużych porcji (jedzenia często, ale mało). Część z nich wskazywała, że wyeliminowała ze swojej diety jedzenie, które może szkodzić zdrowiu bądź powoduje u nich jakieś dolegliwości zdrowotne, a także problemy z nadwagą, tym samym mając wpływ na ich wygląd:

Zdrowie dla mnie łączy się ze zdrowym trybem życia i z odżywianiem, odpowiednimi produktami, w moim przypadku to jest tak pół na pół, odeszłam tam od jakichś ciężkich potraw, zastąpiłam sałatkami (KM_5_28). Staram się dobrze odżywiać, mniej mięsa, staram się jeść dużo warzyw (KM_15_35). Napoje gazowane zamieniłam na soki, na aloes, uzależniłam się od aloesu totalnie, nawilża dziesięć razy lepiej niż woda i ja to czuję, czuję, że mi się poprawia cera, poprawiają mi się włosy od momentu, kiedy jadłam to samo i żyłam tak samo, ale zaczęłam pić więcej tego aloesu i nagle się okazuje, że jest jakaś tam różnica, więc jak widzę że coś działa, to sobie to zatrzymuję w moim trybie życia (KM_5_28).

W porównaniu do mężczyzn, którzy wzięli udział w naszym badaniu, kobiety opisywały wspomniane działanie prozdrowotne bardziej szczegółowo. Wskazywały na znaczenie odpowiedniego doboru spożywanych 
produktów i urozmaiconej diety, jedzenia ekologicznych produktów. Niektóre zaznaczały, że zwracają baczną uwagę na skład kupowanych produktów spożywczych. Charakterystyczne dla kobiet było również podkreślanie, że dieta może pomóc w leczeniu różnych chorób i dolegliwości, a nawet, że spożywanie specjalnych produktów żywnościowych może być lekarstwem na niektóre dolegliwości zdrowotne, na co nie wskazywali mężczyźni: „Stosuję takie, te, jak to się mówi, takie »super pokarmy«, czyli jagody goi albo jakieś tam wodorosty, ale to się wiąże $\mathrm{z}$ dietą, tak, nasiona chia [...], dodaję sobie na przykład do koktajli albo do jakichś posiłków, takie różne dodatkowe substancje (KM_12_34). Powyższe wypowiedzi nawiązują do funkcjonujących w naszej kulturze kulturowych wzorców kobiecości i męskości, w tym wybieranych przez mężczyzn i kobiety sposobów odżywiania. Jak wynika z badań CBOS, mężczyźni częściej od kobiet jedzą tłuszcze zwierzęce, w tym tłuste wędliny i mięsa, natomiast w diecie kobiet częściej znajdują się owoce i warzywa, ale także węglowodany oraz cukry proste. Idealny obiad dla polskiego mężczyzny składa się z mięsa, ziemniaków i piwa, a dla kobiety z dan jarskich: pierogów, makaronów, placków czy kasz (CBOS 2005, 2014). Dodatkowo należy tu wspomnieć, że pomimo obserwowania nieprawidłowości w sposobach żywienia Polaków, to kobiety, bardziej niż mężczyźni, otwarte są na zmiany w zachowaniach zdrowotnych, przede wszystkim w odniesieniu do odżywiania wpływającego na podnoszenie potencjału zdrowotnego człowieka (Wojnarowska 2007). Jak wynika z ogólnopolskich badań, stosowanie specjalistycznych diet, zarówno z powodów zdrowotnych, jak i dla poprawienia sylwetki, częściej cechuje kobiety niż mężczyzn (CBOS 2005, 2014). Współczesne kulturowe wzory kobiecości, w powiązaniu z „tyranią szczupłego ciała” (m.in. Melosik 1999, Wolf 2014), mają swoje konsekwencje nie tylko w stylach żywieniowych kobiet, ale również w zapadaniu przez nie na różnego rodzaju zaburzenia odżywiania (m.in. anoreksję, bulimię, ortoreksję). Jak zaznacza Królikowska, wzory zachowań propagowane przez współczesną kulturę popularną nakładają się na stereotypowe postrzeganie kobiecego ciała. Według stereotypu wyglądu zewnętrznego kobieta powinna być drobna, delikatna, lekka, co koresponduje z zachowaniami zdrowotnymi praktykowanymi przez kobiety. Wybierają one takie aktywności fizyczne, sposoby odżywiania, specjalistyczne diety, aby sprostać wizerunkowi kobiety szczupłej i zadbanej. Jak zaznacza autorka, podejmowanie różnego rodzaju diet, m.in. odchudzających, może prowadzić do problemów ze zdrowiem (Królikowska 2011).

Następnym w kolejności działaniem prozdrowotnym, które było wskazywane zarówno przez kobiety, jak i przez mężczyzn (bez względu na wiek) było unikanie bądź ograniczanie używek (m.in. papierosów, 
alkoholu). Większość rozmówczyń zadeklarowała, że stara się ograniczać wszelkiego rodzaju używki:

Nie palę, staram się nie pić w strasznie dużych ilościach ani też nie imprezować w jakiś mocny sposób, więc jak raz na jakiś czas wyjdę gdzieś i powiedzmy wypiję dwa piwa czy kilka »shotów«, to nie uważam, żeby to było w jakiś sposób strasznie negatywne dla mojego organizmu (KM_3_24). Nie palę papierosów, mam tego świadomość, (że to jest szkodliwe - przyp. aut) (KM_10_30). [...] no staram się [...] nie pić alkoholu, nie palić papierosów. To nie znaczy, że nie zdarza mi się odejście o tego, ale wiem, że nie powinnam, tak, powinnam unikać (KSR_5_47).

Niektóre rozmówczynie wspominały, że nie stosują żadnych używek, przede wszystkim, że nigdy nie paliły papierosów: „No nie palę, wręcz niedobrze mi, jak ktoś zapali, nie znoszę tego zapachu, alkohol też bardzo rzadko (KSR_9_54); „Papierosów nie palę, no alkohol, no przecież jak się pójdzie na wesele to trzeba za zdrowie młodych też wypić [...]” (KST_14_86).

Część respondentek wspomniała, że rzuciły palenie. Przede wszystkim ze względów zdrowotnych: „Nadużywałam alkoholu i papierosów. [...] bez żadnej świadomości (że to jest wbrew mojemu zdrowiu - przyp. aut.) [...]. I jedno i drugie absolutnie nie służy mi. Jedno rzuciłam znacznie wcześniej, bo 20 lat temu, papierochy, a drugie stosunkowo niedawno. Bo jedno, tamto mi nie służyło i alkohol też nie” (KSR_11_6o). Nieliczne $\mathrm{z}$ nich wspomniały, że oprócz dolegliwości zdrowotnych związanych $\mathrm{z}$ paleniem papierosów argumentem do rzucenia tego nałogu była namowa najbliższej rodziny:

[...] coraz więcej tutaj miałam muzyki w klatce piersiowej. Takie świsty, gwizdy. A i jeszcze o tego mojego wnusia. Mówił - »babcia śmierdzisz papierosami, babcia śmierdzisz papierosami«. Ja mówię, żeby dziecko mi mówiło »babcia śmierdzisz papierosami«. I wchodziłam do domu, proszę pani, smród w całym domu. Skończyłam [...]. A wie Pani z czego jestem dumna? Właśnie z tego, że nie palę papierosów i z tego, że zostawiłam mojego męża (KST_3_65).

Warto tutaj dodać, że na podstawie analizy wypowiedzi na temat zachowań prozdrowotnych oraz odpowiedzi na inne pytania zadane podczas wywiadów można było odnieść wrażenie, że wśród kobiet, które wzięły udział w naszym badaniu, więcej rozmówczyń nie stosowało używek. Prawdopodobnie jednak pytane o to, jak dbają o zdrowie, raczej myślały o pozytywnych działaniach podejmowanych przez siebie, a nie unikaniu określonego ryzyka, bądź też brak nałogu traktowały jako coś normalnego, naturalnego w ich przypadku i nie pomyślały, by wspomnieć o tym jako o podejmowanym działaniu na rzecz swojego zdrowia. Biorąc 
pod uwagę kulturowe koncepcje kobiecości i męskości, zachowania antyzdrowotne, do których należą m.in. palenie papierosów, nadużywanie alkoholu czy też ryzykowne zachowania na drodze, wpisują się bardziej w tradycyjny wzorzec męskości niż kobiecości. Przede wszystkim papieros jawi się jako stereotypowy symbol „prawdziwego mężczyzny”. Picie czy nawet nadużywanie alkoholu przez mężczyzn jest też znacznie bardziej akceptowane społecznie niż stosowanie używek przez kobiety.

Kolejne działania kobiet podejmowane na rzecz ich zdrowia, to czynności związane z profilaktyką zdrowotną, tj. regularne kontrole lekarskie, profilaktyczne badania: „Chodzę na okresowe badania i wzroku, bo noszę okulary, i dentystyczne, te zwykłe u internisty, morfologie i inne dziwne rzeczy [...]. Po prostu badam się regularnie, jak już idę do lekarza, to wszystko po kolei idzie do sprawdzenia [...]" (KM_3_24). Charakterystyczne dla kobiet było wymienianie szczegółowych działań profilaktycznych, które przeprowadzają na rzecz swojego zdrowia - wspominały o wykonywaniu badań krwi, badaniach ginekologicznych (cytologia, badanie piersi, mammografia), USG różnych narządów, kontroli ciśnienia krwi (podczas specjalistycznych wizyt, jak również samodzielnie, $\mathrm{w}$ domu): „Robię sobie co roku badania krwi - raczej pełny pakiet, bo usg piersi, cytologia, ginekolog” (KM_13_34). Kobiety deklarowały korzystanie z porad wielu specjalistów, m.in. okulisty, stomatologa, endokrynologa, neurologa. Badane bardziej zdawały się na lekarzy i ich diagnozy w określaniu stanu zdrowia niż na wsłuchiwanie się we własny organizm oraz samodzielne decydowanie o rozpoczęciu leczenia, ewentualnie zastosowaniu alternatywnych form leczenia, na co częściej wskazywali mężczyźni:

Chodzę do lekarza, jak coś mi jest lub jak źle się czuję (KM_1_21). Staram się dostosować do wskazówek lekarzy (KM_9_30). [...] Jeśli mam chorobę zdiagnozowaną lub coś mi dolega, to zwracam się z tym do lekarza i przyjmuję leki, które są potrzebne. (KM_11_34). W momencie, kiedy wiem, że coś jest z moim organizmem nie tak, to idę do lekarza i drążę temat (KM_13_34). No i biorę wszelkiego rodzaju leki i systematycznie dbam o wszystkie wizyty u endokrynologa (KST_3_65).

Część kobiet zaznaczyła, że postępuje według ustalonego harmonogramu, który realizuje od lat, niektóre wspominały, że na badania chodzą zawsze systematycznie:

No i staram się sukcesywnie do lekarzy chodzić i sprawdzać to, co się ze moim stanem zdrowia dzieje. [...] mam taki harmonogram, że idę na pewno do endokrynologa, mam badania osteoporozy. To w zależności. Jedne są co pół roku kontrolne, drugie są co rok itd. Mam taki harmonogram działań, który realizuję już od lat (KSR_7_49). [...] robię sobie takie profilaktyczne, standardowe 
badania. [...] robię sobie USG piersi, robię sobie cytologię, teraz robię badania z krwi i takie podstawowe i już. Jak coś jest, to drążę, i okulistę, bo mam wadę wzroku, to więc musze sobie tam kontrolować. Bo się sypie trochę czasami (KSR_3_42).

Niektóre badane mówiły, że profilaktyka zdrowotna, korzystanie z porad lekarskich oraz stosowanie się do zaleceń lekarzy należą do ich głównych działań na rzecz zdrowia. W tym przypadku wystąpiły różnice pomiędzy kobietami reprezentującymi różne kategorie wiekowe, co zostanie szczegółowo omówione w dalszej części opracowania. Tylko nieliczne rozmówczynie przyznały, że nie wykonują badań kontrolnych w sposób regularny: „[...] właśnie zbieram się od pół roku, żeby to zrobić, codziennie postanawiam, że pójdę i się zapiszę” (KSR_2_41); „Wiem, że powinnam iść do lekarza, odkładam, odkładam, ale w końcu idę" (KSR_5_47). Również w tym przypadku miał znaczenie wiek respondentki.

Kobiety częściej niż mężczyźni podkreślały, że oprócz regularnego kontrolowania swojego zdrowia starają się nie bagatelizować niepokojących objawów, dlatego też zasięgają porad lekarzy i stosują się do ich zaleceń. Przede wszystkim leczą zdiagnozowane choroby, co nie zawsze miało miejsce w przypadku mężczyzn. Żadna z kobiet nie wspomniała, że wystarczające są dla niej wizyty lekarskie bądź badania, które należy wykonać ze względu na aktywność zawodową - tzw. badania okresowe w pracy. Wręcz przeciwnie, część kobiet uznała, że tego typu działania, nie są wystarczające i należy zadbać o zdrowie we własnym zakresie:

Chodzę regularnie na wszystkie kontrole, które mi są wyznaczane we wszystkich tych chorobach, które mam, stosuję się do zaleceń lekarzy i to mi pozwala w sumie egzystować, nie powiem, że czuję się cudownie, że dostaję tak cudowne leki, że wszystko mi mija, bo tak nie jest, ale na pewno polepsza to komfort mojego życia (KST_2_64). Co roku robię badania. No może co półtora roku idę do ginekolożki, robię cytologię. Co roku robię sobie te badania, morfologię, krew itd., różne kreatyniny i [...] co roku chodzę do przychodni endokrynologicznej, z osteoporozą. I tego pilnuję. Osteoporozy pilnuję istotnie, bo biorę leki systematycznie i tyle. [...] trzeba od czasu do czasu to sprawdzić. [...] W pracy to jest raz na 5 lat i to jest bicie piany, a nie badania. Nawet nie zrobią ci głębokich badań krwi, tylko podstawowe [...]. Uważam, że co roku jak sobie zrobię te badania jakieś tam, prywatnie to jest ok (KST_7_70).

Jak wynika $\mathrm{z}$ analizy zebranych danych, kobiety cechowało większe niż mężczyzn zainteresowanie własnym ciałem i stanem zdrowia. Jak już wspomniano w poprzednich podrozdziałach, ze względu na specyfikę procesu socjalizacji, mają one od mężczyzn większą wiedzę na temat zapobiegania i leczenia chorób, co wykorzystują nie tylko 
w odniesieniu do swojego zdrowia, ale także zdrowia innych (dzieci, mężów, starszych rodziców). Jak zaznacza Tobiasz-Adamczyk, kobiety częściej też mają tendencje do szybszego reagowania na pierwsze symptomy chorób (Tobiasz-Adamczyk 2000). Ich społeczne role, a przede wszystkim rola matki, wiążą się z szeregiem zachowań związanych ze zdrowiem, które są częściej praktykowane przez kobiety niż przez mężczyzn. W polskich gospodarstwach domowych, niezależnie od modelu życia małżeńsko-rodzinnego, osobą odpowiedzialną za prowadzenie domu jest częściej kobieta, co jest zgodne ze stereotypem kobiecych ról płciowych. Działania składające się na prowadzenie gospodarstwa domowego pośrednio lub bezpośrednio wiążą się ze zdrowiem, a także należą do czynności wykonywanych niemalże codziennie. Kobiety więc systematycznie biorą odpowiedzialność za zdrowie, nie tylko swoje, ale także członków rodziny (Ostrowska 1999, Tobiasz-Adamczyk 2000, Titkow, Duch-Krzysztoszek, Budrowska 2004, Dzwonkowska-Godula, Garncarek 2015).

W każdej z badanych kategorii wiekowych kobiet pojawiły się wskazania na temat przyjmowania suplementów diety oraz witamin. Rozmówczynie deklarowały, że stosują je szczególnie w okresie zwiększonego ryzyka infekcji. Kobiety bardziej szczegółowo niż mężczyźni opisywały ten rodzaj zachowania prozdrowotnego. Wspominały, że starają się dbać o podniesienie odporności czy wzmacniać swój organizm, szczególnie $\mathrm{w}$ walce $\mathrm{z}$ jakimiś infekcjami, właśnie poprzez przyjmowanie witamin i minerałów:

No na pewno jakieś tabletki, żeby odporność [...], jakąś witaminę C, czy różne takie właśnie (KM_7_28). Oczywiście biorę jakieś witaminy, witaminę C, magnez, teraz jak mam ten sport, no to magnez jest bardzo ważny dla mnie, wapno czasami, bo mam jakieś alergie, więc to jest mi potrzebne od czasu do czasu, jak coś zjem i przypadkiem wysypie mnie gdzieś [...] (KM_3_24). Biorę witaminę A+E czy rutinoscorbin (KST_12_84).

Do działań prozdrowotnych niektóre kobiety zaliczały odpowiedni tryb życia i higienę, z którą wiązały przestrzeganie czystości, stosowanie odpowiednich kosmetyków, a także odpowiednią liczbę godzin przeznaczonych na wypoczynek i sen: „O czystość, o higienę życia, o higienę jedzenia. [...] wstaję rano, po przespanej nocy, myję się, biorę regularnie leki, rozwiązuję dużo krzyżówek, aby ćwiczyć umysł, spaceruję lub ćwiczę, takie rzeczy, co mówiłam też wcześniej, dbanie o higienę, odżywiam się regularnie” (KST_12_84). Mężczyźni biorący udział w badaniu, w przeciwieństwie do kobiet, mówili o higienie bardzo ogólnie. Kojarzono ją jedynie z przestrzeganiem czystości. Nie dokonywano jednak szczegółowego opisu dbania o nią, tak jak to miało miejsce 
w przypadku kobiet. Mówiąc o higienie osobistej jako prozdrowotnym działaniu, część kobiet wskazała również, że odpowiednio dobiera kosmetyki i środki czystości: „Chociażby taka higiena osobista, bo to też ma wpływ. Codzienne mycie ciała, dbanie o swoje włosy, te wszystkie odżywki, kosmetyki to też nie jest dbanie jedynie o wygląd zewnętrzny, ale ma też wpływ na nasze wnętrze" (KM_9_30). Jedna z badanych podkreśliła, że stosuje tylko ekologiczne produkty, inna - że ze względu na problemy zdrowotne musiała wyeliminować niektóre kosmetyki, zawierające szkodzące jej składniki: „Kosmetyki, które używam, wszystkich, prawie wszystkich, ekologicznych, środki czystości to samo" (KM_12_34).

Pojedyncze deklaracje badanych kobiet dotyczyły konieczności zapewnienia własnemu organizmowi odpowiedniej ilości snu jako przykładu zachowania prozdrowotnego. Podkreślano znaczenie trzymania się stałych godzin pójścia spać ze względu na różnego rodzaju procesy fizjologiczne i regenerację organizmu. Jedna z kobiet dbała także o jakość snu poprzez zapewnienie sobie odpowiednich warunków do wypoczynku:

Dbam o to, żeby w pomieszczeniach, w którym śpię było ciemno, nie było komputera, telefonu, telefonu nie, ale na przykład innych sprzętów typu telewizor. O to dbam, dbam o to, aby spać dobrze, z odpowiednią ilością snu (KM_11_34). Pilnuję też czasu, znaczy godziny pójścia, kładzenia się spać, tak, żeby między dziesiątą a jedenastą się położyć i to, jak zaczęłam tego pilnować, to faktycznie też od razu się zaczęłam lepiej czuć, bardziej wypoczęta [...]. Bo od tej jedenastej mniej więcej regeneruje się wątroba i pęcherzyk żółciowy, czyli te wszystkie procesy [...] (KM_12_34).

Nieliczni badani (niezależnie od płci i wieku) wskazywali na alternatywne sposoby leczenia jako pomagające zachować im dobre zdrowie bądź wspomóc konwencjonalne leczenie różnych dolegliwości. Niektórzy zaznaczali, że leczą się również różnymi domowymi/,babcinymi” sposobami. Kobiety jednak zdecydowanie rzadziej niż mężczyźni deklarowały stosowanie alternatywnych sposobów leczenia. W nawiązaniu do wcześniej wymienionych działań prozdrowotnych nasze rozmówczynie częściej powierzały swoje zdrowie w ręce specjalistów.

Do specyficznych działań prozdrowotnych, czyli realizowanych jedynie przez kobiety, zaliczono dbanie o zdrowie psychiczne poprzez relaks, stosowanie medytacji, słuchanie relaksującej muzyki. Tylko kobiety (nieliczne) wspomniały, że korzystają z zabiegów rehabilitacyjnych - stacjonarnych oraz wyjazdowych (pobyty w sanatoriach) bądź SPA, na co nie wskazywali mężczyźni, którzy wzięli udział w badaniu. Pojedyncze badane podkreśliły, że dbają o zdrowie, odpowiednio ubierając się, spacerując na świeżym powietrzu, a także utrzymując aktywność 
umysłową (rozwiązują krzyżówki, korzystają z różnego rodzaju kursów, uczestniczą w zajęciach Uniwersytetu Trzeciego Wieku). Należy podkreślić, że tylko nieliczne kobiety wspomniały, że część działań na rzecz zdrowia zrealizowały za namową osoby bliskiej. Mąż jednej z nich namówił ją do zmiany antyperspirantu na bezpieczniejszą wersję. W drugim przypadku - narzekanie wnuczki na dym papierosowy było jedną z przyczyn, dla której kobieta rzuciła palenie. Jednakże, jak podkreśliła badana, na zerwanie $\mathrm{z}$ nałogiem zdecydowała się przede wszystkim z powodu niekorzystnych dolegliwości zdrowotnych. Nieco inaczej wyglądała sytuacja mężczyzn, bowiem niezależnie od wieku badanego mężczyźni potwierdzili, że bardzo często podejmują działania zdrowotne za namową bliskich.

Jeśli chodzi o mężczyzn, którzy wzięli udział w naszym badaniu, to podobnie jak w przypadku kobiet, najczęściej wskazywano na podejmowanie aktywności fizycznej / ruchu jako działania na rzecz własnego zdrowia. W przypadku mężczyzn pojawiły się m.in. takie wskazania jak: piłka nożna, siatkówka, pływanie, ćwiczenia na siłowni, ćwiczenia w domu (trening siłowy), jazda na rowerze, bieganie, jazda na łyżwach, spacery, praca w ogrodzie, wspinaczka wysokogórska:

Zdrowie to bieganie (MM_9_30). Pływam, jeżdżę na rowerze (MM_13_32). No powiem tak na pewno dwa razy w tygodniu gram w siatkówkę i staram się mniej więcej dwa, trzy, może cztery razy w tygodniu biegać. Jakby to jest praktycznie zawsze. Miałem taką ambicję i w końcu gdzieś tam na siłownię chodziłem, ale teraz brakuje mi czasu (MM_11_31). Ja uprawiam turystykę wysokogórską, więc dość trudno by było to zrobić bez kondycji, starsza córka jest alpinistką - himalaistką, na 7000 ponad włazi [...] (MSR_14_61).

Ponadto mężczyźni deklarowali, że starają się być aktywnymi fizycznie, a także że chcieliby częściej uprawiać sport, jednak brakuje im czasu, silnej woli, ewentualnie chęci do regularnego wysiłku fizycznego, a także, że nie pozwalają im na to kontuzje bądź aktualny stan zdrowia:

No na pewno ćwiczyć dużo [...] uprawiać sport w ogóle. [...] ja niestety jestem trochę leniem w tych sprawach, jak mi się zachce, to będę biegał, biegał, pobiegam troszkę - ale mi się nie chce potem, ale jak na siłownię kupię karnet, to wychodzę, bo wiadomo, to jest w głowie, że zapłaciłem, to muszę zrobić. [...] na pewno aktywność fizyczna, bo troszeczkę się ruszam, na rowerze ciągle teraz jeżdżę, praktycznie komunikacją, samochodem się nie poruszam, chyba że deszcz spadnie (MM_2_22). Jeszcze niedawno, jakieś 1,5 miesiąca temu, ćwiczyłem w domu, miałem specjalnie ułożony plan treningowy, trzymałem się go przez co najmniej pół roku. W ostatnim czasie to porzuciłem, ale już planuję do tego wrócić (MM_6_27). Ale staram się sam dbać o siebie, czyli wymachy rąk, nóg też, takie huśtawki, do góry na ile 
podniosę, skłony nie-skłony, troszeczkę też no, no, biegu ale też przysiady. Tym bardziej, że teraz coś mi się z kręgosłupem działo, ale już wyszło (MST_7_67).

Charakterystyczne dla mężczyzn w przypadku omawianego aspektu postawy wobec zdrowia było nawiązywanie do innych osób (znajomych) uprawiających jakiś sport oraz wskazywanie na ich mobilizujący wpływ na badanego. Rozmówcy wspominali, że porównują swoje plany treningowe i sportowe osiągnięcia (np. przebiegnięte dystanse, czy liczbę przejechanych na rowerze kilometrów):

Na pewno też znajomi, którzy uprawiają sport, na pewno to jest mobilizujące, bo w maju mieliśmy wydarzenie - Łódź, Warszawa i inne stolice w Europie, ile kilometrów, która zrobi. To bardzo coś takiego mobilizuje. Wtedy celowo rowerem do pracy jechałem, żeby nabijać kilometry. [...] znajomi bardzo wpływają na te rywalizacje, plany treningowe. [...] lubię się pokazywać tam (na imprezach sportowych - przyp. aut.), to biegi, to rowerowe imprezy (MM_10_31).

O ile kobiety były aktywne fizycznie przede wszystkim dla zdrowia, dobrego samopoczucia oraz wyglądu, to mężczyźni oprócz tych przyczyn, wspominali również o możliwości sprawdzenia się i rywalizacji z innymi osobami uprawiającymi jakiś rodzaj aktywności fizycznej bądź porównywania osiągnieć sportowych. Sprzyjała ona również kontaktom i spotkaniom towarzyskim. W pojedynczych wypowiedziach aktywność fizyczną/ruch rozumiano również jako pracę na działce bądź aktywność zawodową, która pozwala na utrzymanie dobrej kondycji i zdrowia: „[...] zresztą tak, praca mnie nakręca, ale ten ruch jak najbardziej” (KM_10_30); „Staram się jeździć rowerem, chodzić na spacery, pracuję na działce, generalnie staram się być aktywnym" (MSR_10_56). Zatem w przypadku mężczyzn mamy nieco inne rodzaje aktywności fizycznej niż u kobiet. Jak już wspomniano, funkcjonujące w naszej kulturze stereotypy wyglądu kobiet i mężczyzn przejawiać się mogą w preferowanych przez każdą z płci formach aktywności. Zgodnie $z$ patriarchalnym schematem mężczyźni powinni budować masę mięśniową, wzmacniać wytrzymałość, szybkość i zręczność. Podział na preferowane przez mężczyzn i kobiety formy aktywności fizycznej odzwierciedla tu stereotypowy podział na „silnego mężczyznę” i „słabą kobietę". Tego typu działania kobiet podyktowane są nie tylko zdrowiem, także chęcią osiągnięcia (zgodnie z wcześniej przedstawionym schematem) pożądanego wyglądu. Jak wynika $z$ analizy zebranych wypowiedzi, mężczyźni skupiają się również na elementach rywalizacji, która napędza ich do rozpoczęcia, kontynuacji bądź zaprzestania aktywności fizycznej. 
Kolejnym zachowaniem prozdrowotnym podejmowanym przez mężczyzn było odpowiednie/zdrowe odżywianie się. Badani wspominali o właściwym dobieraniu spożywanych produktów, zwracaniu uwagi na skład kupowanych produktów spożywczych, a także na nieprzejadanie się i ograniczanie bądź rezygnację z tłustego jedzenia i słodyczy: „Poza tym staram się jakoś tam dobrze odżywiać. Nie jem słodyczy. [...] z premedytacją. Bo wiem, że nie jest zdrowy cukier. Więc nie jem tego. No staram się jeść regularnie” (MSR_13_6o). Niektórzy wspominali, że „starają się" bądź dopiero od niedawna zaczęli przywiązywać wagę do sposobu odżywiania się. Kilku mężczyzn zaznaczało, że do zmiany diety zmusiły ich problemy zdrowotne przejawiające się w złych wynikach badań, wykrytych chorobach bądź odczuwanych dolegliwościach:

Rozsądnie staram się jeść. Nawet trochę z rozsądku mam usunięty pęcherzyk żółciowy, ponieważ jak się pojawiło nadciśnienie, wymyślano rożne rzeczy, z kolegą chirurgiem porozmawialiśmy, że jak się zagęszczenie pokazuje, to może usunąć to. Pracę skończyłem w piątek o 13, w sobotę poszedłem, wycieli i w niedzielę rano poszedłem do domu i poniedziałek do pracy. To był taki element prozdrowotny (badany jest lekarzem - przyp. aut.) (MSR_14_61). Miałem tendencję do podwyższonego cukru. Jeżeli w młodym wieku, 30 lat mam już, to znaczy, że mój styl życia, czyli mało aktywności fizycznej, niewłaściwa dieta, jakieś słodkie rzeczy, za dużo węglowodanów, pizzy, fast foodów, muszę coś z tym zrobić, bo wiadomo na co umrę, mając 50 czy 60 lat, będąc już tym starszym człowiekiem. Wziąłem się od razu do działania, teraz z pogardą patrzę na słodkie (MM_10_31).

Część badanych podkreślała, że stara się stosować zdrową dietę, jednakże przy okazji rożnych spotkań rodzinnych i towarzyskich odstępuje od niej:

No chyba, że idę sobie do mamy i wtedy: kotlet schabowy, kapusta okraszona, ziemniaki ze skwarkami (MSR_9_54).

Rozmówcy wspominali, że duże znaczenie dla zdrowia ma także regularność spożywanych posiłków i jedzenie określonych potraw, np. przygotowanych w domu. Niektórym $z$ nich udaje się to osiągnąć, ponieważ nadal mieszkają z rodzicami, którzy przygotowują im jedzenie, o pozostałych dbały żony lub córki. Poleganie na innych, nie tylko w kwestii sposobów odżywiania, było charakterystyczne dla płci męskiej (niezależnie od wieku badanego). Warto tutaj podkreśli, że niektórzy mężczyźni byli namawiani do zmiany sposobów żywienia przez bliskich. Część z nich stwierdziła jednak, że niektóre propozycje nie do końca im odpowiadały: 
Zdrowo się odżywiać, no właśnie pod wpływem dziewczyny, co wspomniałem, ona tu serwuje jakieś obiady, dziś też idziemy wieczorem na festiwal jedzenia, no właśnie, tu i tu, że chcę to - »nie tego nie będziesz jadł, bo musisz trochę dbać o siebie«. [...] healthy food [...] do Green Waya mi każe chodzić, ale nie smakował mi ten Green Way, powiem szczerze, to nie jest dla mnie takie jedzenie (MM_2_22).

Inni mężczyźni, opowiadając o tym, jak zdrowo się odżywiają, często mówili w liczbie mnogiej, mając na myśli całą rodzinę, a w szczególności matki i żony, z którymi razem stosują te same zasady żywienia:

To jest raczej zdrowe jedzenie, domowe zdrowe jedzenie. Tak bym to ocenił. [...] wydaje mi się, że mama wykonuje zdrowe jedzenie i staram się również uzupełniać o jakieś różnego rodzaju witaminy [...] (MM_4_24). Żona raczej zdrowo gotuje [...]. Cholesterol mamy trochę podwyższony, więc od jakiegoś czasu staramy się zwracać na to uwagę. Na to, co jemy właśnie. Żona od córki przyniosła jakieś diety, gazety z przepisami jakimiś. Córka w Internecie wyszukuje też [...] (MST_8_70).

Jednocześnie mężczyźni, częściej niż kobiety, przyznawali się, że ich świadomość znaczenia diety dla zdrowia nie przekłada się na działanie: „Nie przywiązuję uwagi do diety, chociaż staram się nieraz, chociaż staram się nieraz tę dietę [...] trzymać ją, żeby po prostu dbać, ale jest ciężko z tym. Bo nie umiem sobie odmówić na przykład, powiedzmy fast foodów, co jest niezdrowe” (MM_9_30). Część z nich przyznawała, że nie są zbyt restrykcyjni w sposobie odżywiania się i zdarza im się spożywać „niezdrowe” jedzenie. Warto tu jeszcze dodać, że niektórzy badani zaznaczali, iż starają się prawidłowo odżywiać nie tylko dla zdrowia, ale również dla utrzymania prawidłowej sylwetki. Nie stosowano tutaj określenia „dla wyglądu”, które pojawiło się w wypowiedziach kobiet. Mężczyźni mieli tu na myśli sylwetkę, która jest umięśniona bądź pozbawiona odstającego brzucha. Powyższe wypowiedzi nawiązują do funkcjonujących w naszej kulturze kulturowych wzorców kobiecości i męskości, w tym wybieranych przez mężczyzn i kobiety sposobów odżywiania, a także preferowanego wyglądu.

Równie często badani deklarowali unikanie, ograniczanie bądź rezygnację ze stosowania używek. Przede wszystkim wspominali o ograniczaniu palenia papierosów (np. zamianę na papierosa elektronicznego:

Rzuciłem fajki, [...] (zamieniłem - przyp. aut.) na elektroniczne, ekologiczne. [...] wiesz co, palenie to jest drogi sport i niezdrowy to raz, a dwa, że kiedyś wróciłem z pracy i dziecko powiedziało do mnie: »tata, fuj«. No, poważnie, syn tak do mnie powiedział i na drugi dzień od razu zacząłem palić elektronika. Tak, że tutaj dzieciak był takim motorem, żeby rzucić fajki (MM_13_32). 
Oczywiście zero używek, ja ani nie palę, ani nie piję [...] piję, ale w bardzo, bardzo rozsądnych ilościach, okazjonalnie [...]. Generalnie nienawidzę uzależnień, jeśli jest jakaś osoba uzależniona od alkoholu, narkotyków, kawy, papierosów, to też jest to dla mnie słaba osoba, używki mają wpływ na zdrowie i na wygląd przede wszystkim (MM_15_37).

Nieliczni badani mówili o całkowitej rezygnacji z palenia papierosów, nie tylko ze względów zdrowotnych, także ekonomicznych („ponieważ są drogie"). W odniesieniu do napojów wysokoprocentowych część młodych mężczyzn wspominała, że w ogóle nie pije alkoholu, bądź pije go „z umiarem”. Takie picie wiązało się w ich opinii z piciem „w rozsądnych ilościach”, okazjonalnie bądź „nieupijaniem się w trupa”:

Ja nigdy w życiu papierosa nie zapaliłem i nie chcę, alkoholu też, ale wiadomo, czasem trzeba się napić, ale z umiarem (MM_2_22). Alkohol - też nie unikam, ale to tak czasami, zależy od okazji, nie upijam się już w trupa. [...] staram się nie nadużywać alkoholu [...]. Palę na imprezach (MM_5_26). No nie palę, bo to szkodzi. Alkohol zdarza się okazjonalnie (MM_9_30).

Nieliczni mężczyźni wspomnieli, że w ogóle nie piją alkoholu. Jeden $z$ badanych zwrócił uwagę na kwestie moralne związane $z$ nadużywaniem substancji psychoaktywnych (mężczyzna ten działał w harcerstwie):

Paliłem papierosy przez parę lat i rzuciłem. Tak, że to ważny ruch dla mojego zdrowia. Ostatnio też nie piję w ogóle alkoholu, chociaż to nie był taki ruch związany z moją dbałością o zdrowia, ale z moją pracą w harcerstwie, to było takie wyzwanie bardziej moralne. Wydaje mi się, że to też ma dobry wpływ na zdrowie. Jak człowiek po imprezie budzi się z kacem, a bez kaca to na pewno czuję się 100 razy zdrowszy. Ostatnio mi się wydaję, jak nie piję tego alkoholu z 3-4 miesiące, może mi się węch trochę poprawia, smak. Nie wiem, czy to jest wrażenie, czy rzeczywiście tak jest (MM_6_27).

Jak już wspomniano, w grupie kobiet pojawiło się więcej wskazań nawiązujących do całkowitej rezygnacji z używek. Tylko mężczyźni wspominali, że ograniczanie picia alkoholu nie jest wskazane, a niektórym wręcz nie mieści się w głowie. W naszej kulturze papieros nadal stanowi symbol męskości, a spożywanie alkoholu przy różnego rodzaju okazjach jest normą. Odmówienie wypicia toastu może zostać uznane za niestosowne. W patriarchalnej kulturze, męskość od wieków kojarzona jest z używaniem wspomnianych substancji psychoaktywnych, tj. papierosy czy wysokoprocentowe alkohole, a także istnieje większe przyzwolenie dla mężczyzn je stosujących. (min. Ostrowska 2006, Królikowska 2011), czego przykładem są następujące wypowiedzi badanych: 
No pić, to jak to alkohol, to też ograniczyć, no a [...] nie całkiem, bo to też niezdrowo podobnież (śmiech), nawet lekarze mówią [...] mam takich znajomych, że jak zaczną tego, to ze skrajności w skrajność [...]. Koń jak gonitwę zrobi, to się go też od razu do stajni nie zamyka, tylko się jeszcze go puszcza, żeby pochodził, nie? (MST_3_63). I aktywny styl życia. I oczywiście nieunikanie żadnych, że tak powiem uciech życia codziennego. Chociażby dobre winko do obiadu czy tam od czasu do czasu dobra wódeczka to jest wszystko normalne. Zresztą, jak mój ojciec jeszcze żył, to ten nasz znajomy lekarz u nas był, jakaś impreza była, tata mówi: „O jak ja bym się koniaku kiedyś napił«. Mama: »gdzie ty z tym swoim [...] « (Lekarz - przyp. red.): »Pani J., jak się ma 92 lata, kieliszek koniaku nikomu nie zaszkodzi, a wręcz odwrotnie, nawet może pomoże« (MST_5_64). Przede wszystkim ja zawsze podchodzę nawet do tych moich chorób i jakiś innych rzeczy z humorem. Humor jest bardzo ważny. Mówią »śmiech to zdrowie« i rzeczywiście tak jest. Mało tego, słucham organizmu i chcę na przykład winogrono, to biorę winogrono, chcę się lampkę wina napić, to się napiję, alkoholu bardzo mało pije, ograniczone ilości, ale mam ochotę na rybę, na flaczki [...] (MST_7_67).

Badania profilaktyczne i kontrole lekarskie oraz leczenie chorób i dolegliwości to kolejne działania podejmowane na rzecz zdrowia przez mężczyzn (realizowane $z$ różną częstotliwością przez poszczególne kategorie wiekowe mężczyzn). Należy tu jednak zaznaczyć, że były one deklarowane rzadziej niż przez kobiety, nie mówiono również o regularności kontroli lekarskich, na co zwracały szczególną uwagę rozmówczynie. Część mężczyzn zaznaczała, że wykonują badania raz na kilka lat, nawiązywano również do tzw. „badań okresowych” w związku z aktywnością zawodową. Dla niektórych mężczyzn badania okresowe w pracy były jedynym kontaktem ze służbą zdrowia. Ich zdaniem tego typu badania są łatwo dostępne, a także nie wymagają ponoszenia dodatkowych kosztów (związanych z czasem i pieniędzmi): „Profilaktyka jest najważniejsza. Czyli obserwować siebie i jeżeli są jakieś objawy niepokojące, to od razu się testować. Eee ja, znaczy w pewnych wypadkach warto robić badania okresowe, ja akurat ze względu na pracę takie badania robię co 2,3 lata. Ale to zależy, teraz mam pozwolenie na 5 lat. Bo miałem dobre wyniki wszystkie” (MST_4_64). Nieliczni rozmówcy deklarowali wykonywanie badań profilaktycznych „na własną rękę” lub korzystanie z prywatnych wizyt lekarskich. Takie zachowania tłumaczono trudnościami w otrzymaniu świadczenia w ramach ubezpieczenia zdrowotnego bądź brakiem wytrwałości w szukaniu i oczekiwaniu na pomoc lekarską w ramach Narodowego Funduszu Zdrowia. Mężczyźni wspominali, że bardzo często namawiani są przez swoich bliskich do wykonywania badań. Widać tu przede wszystkim znaczącą rolę kobiet w kształtowaniu postaw mężczyzn wobec zdrowia. Jak już wspominano, zgodnie z patriarchalną 
koncepcją płci to do kobiet należy dbanie o zdrowie bliskich. Część rozmówców zaznaczyła, że na kontrole lekarskie umawiani są przez żony bądź córki:

No tylko ten okulista. No i do lekarza pierwszego kontaktu, ale to rzadko. No jak jakaś większa grypa czy jakieś tam zapalenie, to wtedy trzeba wziąć antybiotyk. Ale tak, to nie chodzę. Żona o mnie bardzo dba [...]. No w pracy, kiedyś się robiło (badania okresowe - przyp. aut.), ale to było dawno. A teraz to tak raz na rok, no chyba, że jakoś słabiej się czuję [...]. Córka się dowie, to wtedy mnie wygania i muszę iść. Raz to mnie nawet sama zabrała. Prywatnie byliśmy. I mnie zrobiono taki komplet badań [...] (MST_7_70).

Mężczyźni częściej niż kobiety mówili także o wsłuchiwaniu się we własny organizm oraz samodzielnym decydowaniu o rozpoczęciu leczenia, ewentualnie stosowaniu alternatywnych form leczenia jako pomagających zachować im dobre zdrowie bądź wspomóc konwencjonalne leczenie różnych dolegliwości. Zdaniem badanych działania prozdrowotne w przypadku choroby nie muszą oznaczać pójścia do lekarza, równie dobrze mogą polegać na leczeniu się domowymi sposobami. Jak już wspomniano, mężczyźni deklarowali stosowanie różnego rodzaju nalewek alkoholowych, które w ich opinii mogą pomóc w zwalczaniu określonych dolegliwości zdrowotnych (np. gorące piwo z sokiem, wódka, różnego rodzaju nalewki na bazie alkoholu):

Bardzo i wsłuchiwać się w swój własny organizm, wsłuchiwać się. To znaczy, jak cię coś boli, to się tym tak nie przejmować, bo boleć ma prawo, tylko jeżeli zaczyna coś boleć i to dokucza przez parę dni, no to już trzeba na to zwrócić uwagę, prawda (MST_4_64). [...] poszedłem do domu, do mamy, to mi dała polopirynę, to mówię do mamy »dwie mi daj«, i szklankę bimbru wypiłem. I dwie godziny pod pierzyną, cały przykryty przeleżałem, dwa razy się przebrałem, po tych dwóch godzinach kaszel mi minął. [...] teraz, jak się przeziębię, to biorę piwo, sok malinowy do tego grzeję i to sobie wypije, wygrzeje się, wypocę się i mi starczy (MST_6_66). [...] nie chodzę do lekarzy, do lekarza, tylko wolę przesiedzieć te trzy dni w domu, no bo, no z głupim przeziębieniem aż czasem głupio pójść do lekarza (MM_1_21).

Część mężczyzn przyznała, że idą do lekarza dopiero wtedy, gdy zauważają u siebie jakieś bardzo niepokojące objawy, nie zawsze stosują się do zaleceń lekarzy oraz że nie starcza im zapału, żeby kontynuować leczenie: „Migreny mi dokuczają, cyklicznie nieraz coś tam wyskoczy, że mnie natchnie i dobra, idę się przebadać, zrobię sobie albo tomograf i tak dalej. Ale to jest tak rozciągnięte w czasie, że [...]. Lekarz mi przepisał tabletki, no to jak mi się przypomniało, to je brałem. Tak, że, no, to też kuleje” (MM_13_32). 
Powyższe wypowiedzi nawiązują do patriarchalnej koncepcji męskości, w której choroba traktowana jako słabość, do której nie należy się przyznawać. Mężczyźni unikają kontaktów z lekarzami, często bagatelizują objawy choroby, a w przypadku wystąpienia uciążliwych dolegliwości zdrowotnych stosują samoleczenie. Widać tutaj wyraźną różnicę w omawianym aspekcie postawy wobec zdrowia występującą między kobietami a mężczyznami. Panie bardziej zdawały się na specjalistów i ich diagnozy $\mathrm{w}$ określaniu stanu zdrowia, również bardziej szczegółowo niż mężczyźni wymieniały rodzaje badań profilaktycznych i narządów, o które dbają.

Mężczyźni, podobnie jak kobiety, które wzięły udział w badaniu, deklarowali przyjmowanie suplementów diety oraz witamin, jako działań, które służą ich zdrowiu. Stosują je szczególnie w okresie zwiększonego ryzyka infekcji. Jednak rozmówcy nie opisywali rodzajów przyjmowanych suplementów diety tak szczegółowo jak kobiety. Nieliczni badani wspominali również, że starają się dbać o higienę osobistą. Działanie to było jednak częściej i dokładniej opisywane przez kobiety niż mężczyzn. Mówiąc o higienie osobistej, mężczyźni mieli na myśli mycie się bądź „niezapuszczanie się". Nie wspominali o higienie jedzenia, jak również nie wskazywano na znaczenie stosowania/doboru odpowiednich środków czystości i kosmetyków do specyficznych potrzeb skóry: „No staram się też nie zapuścić. Golę się codziennie. Jem regularnie” (MST_8_7o). Z deklaracji badanych obojga płci wynika, że to kobiety bardziej dbają o higienę ciała. W przypadku mężczyzn mamy do czynienia z podstawowymi zasadami higieny. Większość z nich nie deklarowała stosowania specjalistycznych kosmetyków do pielęgnacji, w takim stopniu jak kobiety.

Warto także zwrócić uwagę, że część badanych wskazała na czytanie artykułów prasowych lub w Internecie na tematy dotyczące zdrowia. Jeśli chodzi o prasę, to były to czasopisma pożyczane od żon/partnerek (prasa kobieca, „lifestylowa”) lub skierowane do mężczyzn (np. Men’s Health).

Szukam w Internecie jakichś porad. To znaczy, jakich wartości mi może brakować, co mi potrzeba, przy moim odżywianiu się. Szukam w Internecie przeważnie. Albo też zaczerpuję opinii ludzi z podobnymi problemami, wyszukuję w Internecie opinii ekspertów. [...] radzę się również znajomych, pytam, co oni biorą w konkretnych przypadkach itd. (MM_3_22). Czytam miesięczniki, można przeczytać $\mathrm{w}$ Internecie, $\mathrm{w}$ wiadomościach jakichś, o danym stanie zdrowia, na co mężczyzna powinien zwrócić szczególną uwagę, gdy przechodzi na przykład w wieku po trzydziestce, kończy trzydzieści pięć, w okolicach czterdziestki, na co powinno się zwrócić uwagę (MSR_2_39). 
Gdy w analizie uwzględniono „upłciowiony wiek” tj. kulturowe koncepcje kobiecości i męskości zróżnicowane w odniesieniu do ludzi będących w różnych fazach życia, również dostrzeżono pewne różnice w stosunku badanych do omawianego przedmiotu postawy. Wynikają one przede wszystkim z socjalizowania badanych w określonych warunkach społeczno-kulturowych i tym samym specyficznych wobec nich oczekiwań. Okazuje się, że osoby młode, w średnim wieku i stare wskazują na nieco inne działania służące ich zdrowiu. W tej część opracowania spróbujemy zidentyfikować empiryczne przejawy genderyzacji wieku na przykładzie zachowań prozdrowotnych kobiet (w trzech kategoriach wiekowych), następnie zaś w zbiorowości mężczyzn (również w trzech kategoriach wiekowych).

Analizując wypowiedzi kobiet w różnym wieku na temat podejmowanych przez nie zachowań prozdrowotnych, dostrzeżono pewne różnice w ich stosunku do omawianego przedmiotu postawy. Charakterystyczne dla działań na rzecz zdrowia podejmowanych przez młode kobiety było łączenie ich z dbaniem o wygląd. Podobne wskazania pojawiły się również wśród kobiet będących w średnim wieku. Kobiety młode wykazywały się dużą wiedzą na temat zdrowego odżywiania, różnego rodzaju diet. Tylko one wspominały o spożywaniu ekologicznych produktów oraz „super pokarmów”, tj. nasion chia, jagód goji itp. Młode badane wymieniały także różne rodzaje kosmetyków stosowanych w higienie ciała (w tym specjalistyczne i ekologiczne). Charakterystyczne dla tej grupy kobiet było zwracanie szczególnej uwagi na znaczenie aktywności sportowej i w przeciwieństwie do kobiet reprezentujących starsze kategorie wiekowe, przynajmniej w świetle deklaracji, młode respondentki czynnie uprawiały różnego rodzaju aktywność fizyczną. Jako jedyne wspominały również o stosowaniu relaksacji oraz medytacji. Z analizy zebranych danych można wnioskować o większej świadomości młodych kobiety w zakresie dbania o zdrowie niż kobiet będących w średnim wieku i starszych (zwłaszcza o wpływie aktywności fizycznej na stan zdrowia). Świadomość ta ma odzwierciedlenie także w praktyce (zachowaniach prozdrowotnych). W dużej mierze wynika to $\mathrm{z}$ faktu, że młodsze kobiety dorastały w kulturze, w której propaguje się modę na zdrowy styl życia (m.in. dzięki informacjom czerpanym z prasy, programów telewizyjnych itp.).

Jeśli chodzi o reprezentantki średniego wieku, to do najczęściej przez nie wskazywanych działań prozdrowotnych należało leczenie występujących chorób oraz korzystanie z porad różnego rodzaju specjalistów. Równie często badane mówiły o unikaniu bądź rezygnacji z używek. Kobiety będące w średnim wieku dbają o zdrowie przede wszystkim z powodu podupadającej kondycji fizycznej/zdrowotnej (podobne wskazania pojawiły się również w najstarszej grupie wiekowej kobiet). Jednocześnie 
wśród kobiet będących w średnim wieku pojawiło się najwięcej wypowiedzi na temat niesystematyczności w dbaniu o zdrowie. Tłumaczyły ją przede wszystkim wieloma obowiązkami wynikającymi z łączenia przez nie rodzinnych i zawodowych ról. To w tej grupie badanych zauważono osoby, które można zaliczyć do tzw. „sandwich generation” (Miller 1981). Kobiety wspominały, że bardzo często pełnią rolę tzw. „domowego lekarza" - dbając o rodzinę (dzieci i starzejących się rodziców), brakuje im czasu bądź siły, aby zadbać o siebie. O tym zjawisku wspominały nie tylko reprezentantki omawianej tu kategorii wieku, ale również inne kobiety i mężczyźni, którzy wzięli udział w naszym badaniu. W tej grupie badanych kobiet pojawily się uwagi dotyczące dbania nie tylko o ciało, ale również o umysł. Kobiety będące w średnim wieku zwróciły uwagę na konieczności ciągłego rozwoju umysłowego dla psychofizycznej sprawności człowieka: „[...] czyli czytamy, oglądamy, tyle ile wrażeń jesteśmy w stanie skumulować, różnorodnych, czy to z wystaw, z wycieczek czy ze spotkań z ludźmi, to jest ważne. Czyli nasz intelektualny rozwój, czyli harmonia powinna być [...]” (KSR_11_60). Również kobiety stare nawiązywały do aktywności umysłowej (m.in. rozwiązywania krzyżówek, uczestnictwa w zajęciach Uniwersytetu Trzeciego Wieku).

Charakterystyczne dla najstarszej grupy kobiet było wskazywanie na regularne kontrole lekarskie, stosowanie się do zaleceń lekarzy oraz leczenie zdiagnozowanych chorób jako działań prozdrowotnych. Rozmówczynie przywiązywały dużą wagę do medycyny profesjonalnej. Takie zachowania wynikały przede wszystkim z pogarszania się ich stanu zdrowia, ocenianego zarówno obiektywnie, jak i subiektywnie, oraz z szeregu problemów zdrowotnych i odczuwanych dolegliwości. Jak wynika $\mathrm{z}$ analizy zebranych danych, były to dla tej grupy kobiet główne działania prozdrowotne. Badane wspominały również o tym, że dbają o higienę i zdrowy tryb życia. Wskazywały głównie na zmianę sposobu żywienia $\mathrm{w}$ związku $\mathrm{z}$ występującymi problemami zdrowotnymi. Część z nich zaznaczyła, że zażywa ruchu (m.in. spacery, gimnastyka). W przeciwieństwie do młodszych badanych nie łączyły dbania o zdrowie z dbaniem o wygląd. Jak wspomniała jedna z kobiet - „z wiekiem kobiety stają się „przezroczyste”, „niewidoczne”, „nie mają już dla kogo dbać o siebie" (MST_7_7o) (kwestia ta została rozwinięta w rozdziale dotyczącym zachowań na rzecz wyglądu).

Analizując wypowiedzi mężczyzn należących do trzech kategorii wiekowych na temat podejmowanych przez nich zachowań prozdrowotnych, również $\mathrm{w}$ tym przypadku dostrzeżono pewne różnice $\mathrm{w}$ ich stosunku do omawianego przedmiotu postawy. Charakterystycznym dla młodych mężczyzn było łączenie dbania o zdrowie z aktywnością fizyczną/uprawianiem sportu. Jak już wspomniano w rozdziale omawiającym 
komponent poznawczy postawy wobec zdrowia, było ono rozumiane właśnie jako sprawność i kondycja fizyczna. Co ciekawe, mobilizacyjny wpływ na to działanie prozdrowotne mieli znajomi badanych. Wyraźnie widać $\mathrm{w}$ omawianym typie zachowania znaczenie rywalizacji. Pojawiło się ono również u niektórych badanych będących w średnim wieku. Młodzi mężczyźni wspominali także o właściwym/zdrowym odżywianiu się jako zachowaniu pozytywnie wpływającym na ich stan zdrowia. Jednak warto zauważyć, że znaczącą rolę w przypadku tego działania odgrywały ich matki bądź żony/partnerki. To one przygotowywały posiłki bądź namawiały mężczyzn do zmiany stylu żywienia. Młodzi mężczyźni wskazywali również na wartość domowego jedzenia. Wspominali także o unikaniu używek, aczkolwiek, jak wynika $\mathrm{z}$ analizy zebranych danych, świadomość szkodliwości różnego typu substancji psychoaktywnych nie do końca przejawiała się w praktyce/zachowaniach prozdrowotnych tej grupy badanych. Młodzi mężczyźni wspominali o tym, że czytają artykuły na tematy związane $\mathrm{z}$ dbaniem o zdrowie/prowadzeniem zdrowego stylu życia. W porównaniu do badanych będących w średnim wieku i starych można mówić o znacznie większej świadomości zdrowotnej młodych mężczyzn, przede wszystkim w zakresie zdrowego odżywiania, znaczenia aktywności fizycznej, jak również profilaktyki zdrowotnej. Wydaje się, że można dostrzec częściową androgynizację w sposobach myślenia o zdrowiu młodych mężczyzn. Należy zaznaczyć, że podobnie jak młode kobiety, byli/są oni socjalizowani w czasach, w których propaguje się modę na zdrowy styl życia, jednakże, w porównaniu z rówieśnicami, mężczyźni młodzi nadal rzadziej niż kobiety wykorzystują zdobytą wiedzę w praktyce.

Mężczyźni będący w średnim wieku również łączyli dbanie o zdrowie z aktywnością fizyczną. Oprócz uprawiania wymienionych już rodzajów sportu w tej kategorii wiekowej pojawiła się także aktywność związana z prowadzeniem ogrodu bądź pracą na działce. Jak wynika $\mathrm{z}$ analizy zebranych danych, aktywność fizyczna mężczyzn w średnim wieku staje się coraz mniej intensywna, a także, w porównaniu do rozmówców z młodszej kategorii wiekowej, stosuje ją mniej liczna grupa osób. W omawianej grupie wiekowej zauważono również rezygnowanie $\mathrm{z}$ jakiejkolwiek aktywności fizycznej (m.in. z przyczyn zdrowotnych, braku czasu, lenistwa). Badani wspominali także o leczeniu chorób i różnych dolegliwości zdrowotnych (wskazania te pojawiały się częściej niż u młodszych respondentów). Mężczyźni będący w średnim wieku wspominali o właściwym/zdrowym odżywianiu się jako zachowaniu pozytywnie wpływającym na ich stan zdrowia. Przede wszystkim mówili o nieprzejadaniu się i unikaniu ciężkostrawnych/tłustych potraw, nie tylko dla zdrowia, również dla utrzymania szczupłej sylwetki (przede wszystkim szczupłego 
brzucha). Także $\mathrm{w}$ tej grupie znaczącą rolę $\mathrm{w}$ przypadku omawianego działania odgrywały kobiety (żony/partnerki), które przygotowywały posiłki lub namawiały mężczyzn do zmiany diety. Badani wskazywali również na wartość domowego jedzenia. Podobnie jak młodsi mężczyźni zwrócili uwagę na unikanie używek. Jak wynika $z$ analizy wypowiedzi badanych, świadomość szkodliwości różnego typu substancji psychoaktywnych nie do końca przejawiała się w ich zachowaniach prozdrowotnych.

Specyfika najstarszej kategorii wiekowej mężczyzn dotyczy przede wszystkim dbania o odpowiednie odżywianie się (nieprzejadanie się i unikanie tłustych potraw). W tej grupie mężczyzn pojawiły się deklaracje stosunkowo niewielkiej aktywności fizycznej (spacery, praca na działce, praca zawodowa/dorabianie do emerytury). Aktywność fizyczna była rozumiana przede wszystkim jako „bycie w ruchu w ogóle”. Mężczyźni ci, podobnie jak reprezentanci średniego wieku, wspominali o stosowaniu alternatywnych form leczenia, także na bazie alkoholu. To, co zdecydowanie odróżniało ich o młodszych rozmówców, to prawie całkowita zależność jeśli chodzi o dbanie o zdrowie od innych/bliskich osób, zwłaszcza żon i córek. Najstarsi rozmówcy wskazywali na ich ogromną rolę m.in. w stosowaniu odpowiedniej/zdrowej diety, umawianiu wizyt, badań oraz przestrzeganiu zaleceń lekarskich.

$\mathrm{Na}$ zakończenie przyjrzymy się zachowaniom podejmowanym na rzecz zdrowia w poszczególnych kategoriach wieku. Zacznijmy od pokolenia ludzi młodych, spośród których niemal wszyscy przywiązywali dużą wagę do zdrowia. Na pierwszy miejscu w tej kategorii wiekowej pojawiła się aktywność fizyczna jako działanie pozytywnie wpływające na stan zdrowia. Większość młodych osób kojarzyła aktywność fizyczną ze sportem. Należy tutaj przypomnieć, że młode kobiety i młodzi mężczyźni wskazywali na nieco inne rodzaje aktywności fizycznej, a tylko u mężczyzn młodych pojawił się elementy rywalizacji w omawianym aspekcie, na co nie wskazywały ich rówieśniczki. Ludzie młodzi wiązali aktywność fizyczną nie tylko z działaniem na rzecz zdrowia, również na rzecz wyglądu. Analizując ich wypowiedzi, zwłaszcza kobiet młodych, można odnieść wrażenie, że w pierwszej kolejności dbają one o wygląd, natomiast wartością dodaną jest dobre samopoczucie i zdrowie. Aktywność fizyczna maleje z wiekiem badanych. Osoby będące w średnim wieku oraz osoby należące do najstarszej kategorii wiekowej wskazywały również na inne rodzaje aktywności fizycznej, tj. bycie w ruchu, ruch (w ogóle), prace wykonywane na działce. Najmniej aktywni fizycznie byli mężczyźni reprezentujący najstarszą kategorię wiekową. Brak bądź niewielka tego typu aktywność osób starszych wynikała nie tylko $\mathrm{z}$ możliwości ich organizmu uwarunkowanych wiekiem oraz określonych problemów zdrowotnych. Należy tu również zwrócić uwagę 
na uwarunkowania natury społeczno-kulturowej, zwłaszcza na występowanie w naszej kulturze określonych stereotypów starości, która wiązana jest z niedołężnością, a jedyna aktywność, na którą może sobie „pozwolić" starsza osoba, to opieka nad wnukami, ewentualnie spędzanie czasu na działce. W związku z tym starszym osobom (bez względu na płeć), nie wypada być tak aktywnym jak młodym ludziom. Pojawia się wiele obaw przed negatywnymi ocenami nietypowej aktywności ludzi w podeszłym wieku, zatem część z nich nie podejmuje żadnej aktywności fizycznej/sportowej bądź towarzyskiej. W miarę możliwości pomagają jedynie swoim dzieciom lub wnukom. Sytuacja ta powoli jednak ulega zmianie. Przede wszystkim dzięki różnego rodzaju ogólnopolskim i lokalnym programom aktywizującym starych ludzi, (m.in. „Dni Seniora”, „Seniorzy w Akcji”, „Latające Babcie” itp.). Coraz częściej mówi się o nich w telewizji, pojawiają się na ten temat artykuły w prasie. Jednak w różne formy aktywności relatywnie częściej angażują się kobiety, zaś potencjał starszych mężczyzn jest nadal wykorzystywany w mniejszym stopniu (Szimanek, Wejcman 2012-2013).

Również w przypadku sposobów odżywiania się dostrzeżono pokoleniowe różnice. Młodzi ludzie wskazywali na znaczenie odpowiedniej diety i doboru spożywanych produktów. Niektórzy zaznaczali, że zwracają uwagę na skład kupowanych produktów spożywczych, jak również na unikanie ciężkostrawnych potraw. Podkreślali także wartość domowego jedzenia, które ich zdaniem jest zdrowsze od tego, które jest serwowane na mieście, przede wszystkim w różnego rodzaju sieciach fast foodowych. Badani będący w średnim wieku rzadziej wspominali o szkodliwości jedzenia na mieście, natomiast najstarsi w ogóle nie mówili o spożywaniu produktów typu fast food. Im starsi rozmówcy, bez względu na płeć, tym częściej wskazywano na rezygnacje z ciężkostrawnych produktów spożywczych (tzw. kuchni polskiej) oraz konieczności zmiany wzorów odżywiania, stosowania odpowiedniej diety w związku z wiekiem i pojawiającymi się dolegliwościami i problemami zdrowotnymi. W kwestii odpowiedniego odżywiania się zauważono jednak różnice wynikające $\mathrm{z}$ płci badanych. O wymienionych działaniach prozdrowotnych częściej wspominały kobiety niż mężczyźni. Mężczyźni (bez względu na wiek) częściej niż kobiety przyznawali się, że ich świadomość znaczenia diety dla zdrowia nie przekłada się na zachowania.

Jeśli chodzi o kwestię unikania bądź rezygnacji z różnego rodzaju używek jako działania na rzecz zdrowia jednostki, to również w tym przypadku wystąpiły mniejsze różnice pokoleniowe, natomiast znaczenie miała tu płeć badanych. Większość rozmówczyń wspomniała, że nie stosuje żadnych używek, przede wszystkim, że nigdy nie paliły papierosów. Z analizy zebranych danych wynika, że brak nałogów traktowany był 
jako coś normalnego, naturalnego, dlatego też część z nich nie pomyślała, by wspomnieć o tym jako o podejmowanym działaniu na rzecz zdrowia.

$\mathrm{Na}$ wykonywanie badań profilaktycznych częściej wskazywali ludzie młodzi niż osoby w średnim wieku i stare. Warto tutaj zaznaczyć, że młodzi ludzie (bez względu na płeć) przywiązywali wagę przede wszystkim do realizowanego stylu życia (wspomnianego już odpowiedniego odżywiania się, aktywności fizycznej oraz właśnie wykonywania badań profilaktycznych) jako działań korzystnie wpływających na ich stan zdrowia. Przeprowadzanie badań profilaktycznych miało jednak nieco większe znaczenie dla kobiet, niż mężczyzn. Natomiast im starsze osoby, tym częściej wspominano o leczeniu występujących z wiekiem dolegliwości zdrowotnych i chorób. W kategorii osób starych zauważono również większe przywiązywanie, a także zaufanie do medycyny profesjonalnej, przede wszystkim deklarowane przez kobiety. Warto zwrócić uwagę na różnice pokoleniowe dotyczące dbania o higienę jako jednego z działań na rzecz zdrowia. Młodzi ludzie częściej niż osoby w średnim wieku i starsze wspominali o doborze odpowiednich kosmetyków i środków czystości, zwłaszcza młode kobiety odnosiły się do wspomnianego działania. Dla pozostałych badanych dbanie o higienę w kontekście zdrowia znaczyło przede wszystkim przestrzeganie czystości. Charakterystyczne dla reprezentantów średniego wieku było zaniedbywanie swojego zdrowia, jednakże miało ono inne podłoże. O ile kobiety wspominały o problemie godzenia obowiązków związanych z realizowaniem ról rodzinnych i zawodowych, o tyle mężczyźni nawiązywali do zaangażowania w życie zawodowe, pojawiające się problemy zdrowotne, a także niechęć czy też brak cierpliwości jako przeszkody w zajmowaniu się swoim zdrowiem. Jak już wspomniano, charakterystycznym dla najstarszej kategorii badanych było „złożenie” swojego zdrowia w ręce lekarzy specjalistów i zdanie się na medycynę profesjonalną - częściej jednak wskazywane przez kobiety niż mężczyzn. U tych drugich pojawiły się również przykłady korzystania $z$ alternatywnych form leczenia (np. stosowanie nalewek na bazie alkoholu), rzadziej wskazywane przez młodych ludzi. W porównaniu do młodszych respondentów starsi mężczyźni byli uzależnieni od innych $\mathrm{w}$ aspekcie dbania o zdrowie. $\mathrm{Z}$ wypowiedzi starszych mężczyzn, którzy wzięli udział w badaniu, wynika, że w dużej mierze wpływ na ich sposoby odżywiania się, regularne kontakty $\mathrm{z}$ lekarzami oraz zażywanie odpowiednich lekarstw, mają żony lub córki. Jak wspominała część badanych, to one dbają o określoną dietę, częstość wizyt lekarskich, a także przypominają im o zażywaniu stosownych leków.

Co ciekawe, pomiędzy reprezentantami wyodrębnionych tu kategorii wiekowych (bez względu na płeć) wystąpiły również różnice na poziomie używanego przez nich języka. Ludzie młodzi, wymieniając 
podejmowane działania korzystne dla swojego zdrowia, mówili o odpowiednim „stylu życia”, natomiast im starsi rozmówcy/rozmówczynie, tym częściej pojawiały się odwołania do „trybu życia”, „dobrego prowadzenia się", jak również „higieny życia”. Wspomniane różnice wynikają przede wszystkim $z$ socjalizacji badanych $w$ innych warunkach społeczno-kulturowych. Warto tu również dodać, że im młodsi badani, tym częściej pojawiały się przekonania o indywidualnej odpowiedzialności za swoje zdrowie.

Podsumowując dotychczasowe rozważania oraz odnosząc się do postawionych hipotez, należy zaznaczyć, że osoby młode mają większą świadomość znaczenia zdrowia dla kapitału jednostki, przywiązują również dużą wagę do realizowanego stylu życia. Wskazywanie przez młodych ludzi na znaczenie indywidualnej odpowiedzialności za własne zdrowie może wynikać $\mathrm{z}$ faktu, że dorastali oni w kulturze, w której propaguje się modę na zdrowy styl życia. W porównaniu do starszego pokolenia mają oni większą świadomość znaczenia zdrowia, a część z nich, zwłaszcza młode kobiety, częściej niż rówieśnicy przekuwają tę świadomość z czyny. Kulturowa koncepcja kobiecości w odniesieniu do młodych kobiet akcentuje znaczenie zdrowia (m.in. w związku z rolą reprodukcyjną) i wymaga od nich dbałości o ten zasób. Z kolei w koncepcji męskiej młodości dobrą kondycję i witalność traktuje się jako naturalne atrybuty mężczyzny, pozwalające im na rzadsze zajmowanie się zdrowiem. W kulturowej koncepcji kobiecości odnoszącej się do kolejnych faz życia utrwala się wyuczony w dzieciństwie nawyk dbania o zdrowie. Jednak w związku z „przepisami” roli kobiety troszczy się ona przede wszystkim o zdrowie najbliższych, rzadziej własne („kobiety nie mają czasu chorować"). $\mathrm{Z}$ wiekiem następuje większa profesjonalizacja dbania o zdrowie (w każdej kategorii płci). Przy czym zachowania osób w średnim wieku i starych wobec zdrowia są zróżnicowane ze względu na płeć, co wynika z realizowania przez nie patriarchalnych wzorów kobiecości i męskości. Kulturowe koncepcje męskości powiązane ze średnim wiekiem i starością cechuje przywiązywanie mniejszej wagi do zdrowia w porównaniu do rówieśnic. Należy również podkreślić, że im starsi badani, tym częściej polegają na innych (żonach, córkach) w omawianym tu aspekcie postawy.

\subsubsection{Zachowania antyzdrowotne a płeć i wiek (Emilia Garncarek)}

W wywiadach swobodnych zapytaliśmy badanych/ne również o ich zachowania antyzdrowotne, czyli takie, które mogą prowadzić do niszczenia zdrowia, jego osłabienia czy też do świadomego wprowadzania się 
w stan choroby. Biorąc pod uwagę ogół uzyskanych wypowiedzi, zauważono, że większość rozmówców odpowiadała podobnie na pytanie o to, czy podejmują jakieś działania szkodzące ich zdrowiu. Jednak ze szczegółowej analizy wypowiedzi uwzględniającej płeć badanych, ich wiek oraz „upłciowiony wiek” (gendered age) wynika, że podobnie jak w przypadku poprzednich aspektów składających się na postawy wobec zdrowia, także tutaj wystąpiły różnice pomiędzy poszczególnymi kategoriami badanych.

W pierwszej kolejności zajmiemy się zachowaniami antyzdrowotnymi kobiet (bez względu na wiek). Będą one przedstawiane według częstotliwości występowania - od najczęściej wskazywanych, po te, które były wymieniane przez nieliczne badane (analogicznie zostaną scharakteryzowane działania antyzdrowotne podejmowane przez mężczyzn).

Kobiety zatem najczęściej wskazywały na niewłaściwe odżywianie się jako działanie niesprzyjające ich zdrowiu. Część z nich mówiła o spożywaniu niezdrowych produktów, np. „śmieciowego jedzenia/jedzenia typu fast food":

No wiem, że się nie za dobrze odżywiam. To na pewno ma wpływ na moje zdrowie. [...] no tzw. śmieciowe jedzenie. Wiem, że może powinnam bardziej [...] jakoś tak odżywiać się, ale na razie mi nie wychodzi. Z różnych względów. Czasu, ochoty, no tak właśnie (KM_1_21). Czasami jakieś frytki głupie, bez sensu zjem. Jakiś tam McDonald, bo dzieci jedzą, to ja też. Albo nie jem cały boży dzień, chociaż wiem, że nie powinnam tego robić, bo potem rzucę się na jedzenie wieczorem" (KSR_3_42).

Badane wspominały także o nieregularności spożywanych posiłków: braku stałych pór posiłków, niejedzeniu śniadań, objadaniu się na noc:

To, że nie jadam śniadań; to że jeżeli już coś jem, to na szybko i tak trochę, może mało wartościowo (KM_4_27). Być może niehigieniczny tryb życia, bo ja nie jem rano, jem wieczorem, ale ja rano nie mogę zjeść, bo ja nie nauczyłam się nigdy jeść rano, czasami mi się o 15 przypomni, że jeszcze dzisiaj nic nie jadłam i wtedy usiądę i coś tam zjem, ale bardzo często jak wrócę do domu o 19-tej (KSR_8_53).

Niezależnie od wieku większość kobiet wspomniała również o jedzeniu zbyt dużej ilości słodyczy, część z nich podkreślała, że spożywanie słodyczy jest ich największą słabością: „Uwielbiam słodycze ale też czuję, że niestety mnie gubią. Więc też muszę się ograniczać. [...] jestem tylko człowiekiem i mam swoje słabości, nie raz się rzucę na coś czego nie powinnam (KSR_3_42). Jak podkreśla Antonina Ostrowska, istnieją kulturowe zróżnicowania oczekiwań co do sposobu odżywiania się kobiet i mężczyzn - np. ulubionych potraw. W kulturze patriarchalnej, 
mężczyźnie bardziej przystoi spożywanie golonki, a kobiecie - ciastek i lodów. Wdrożenie tych oczekiwań kształtuje odpowiednio gusty i wybory konsumpcyjne obu płci (Ostrowska 1999). Nieliczne respondentki wspominały również o jedzeniu zbyt dużej ilości posiłków (np. mówiły, że od czasu do czasu „folgują sobie z jedzeniem”), jak również piciu zbyt dużej ilości kawy:

Jak nieraz pofolguję sobie $\mathrm{z}$ jedzeniem, z którym nie powinnam, no ale w końcu, wie pani, coś tam siedzi u człowieka w głowie (KST_3_65). [...] może w święta się troszkę przejadam, ale potem raczej wracam do normy i raczej nie ma nic takiego świadomego, żebym wiedziała, że mi to szkodzi, ale mimo wszystko [...] (KST_5_67). Wiem, że mi szkodzi kawa, ale ją piję. Bo z kawy nie zrezygnuję, ale z ekspresu i piję raz dziennie. Więc nawet pan doktor kardiolog mnie rozgrzeszył (KST_5_67).

Pojedyncze wypowiedzi kobiet w ramach omawianego tu działania dotyczyły braku konsekwencji w stosowaniu przez nie diety ze względu na zdiagnozowane problemy zdrowotne:

No jeżeli chodzi o tą dietę, to nie jestem taka konsekwentna, żeby tej diety przestrzegać, bo mam cukrzycę typu drugiego i powinnam bardziej zwracać uwagę na to, co jem, staram się, nie powiem, że nie, cukier w tej chwili mam w normie, w związku z tym zeszczuplałam co jest na plus przy tej chorobie, ale nie raz sobie pozwalam, ale nie na słodkie rzeczy, bo ich nie lubię, to są sporadyczne przypadki, żebym coś słodkiego zjadła, ale inne rzeczy, wędliny nie takie jak powinnam jeść, skusze się, mam po prostu słabą wolę (KST_2_64).

Zdaniem kobiet niewłaściwe odżywianie nie tylko wpływa na stan zdrowia, oddziałuje także, zwłaszcza w negatywny sposób, na wygląd:

Jadam nieregularnie, mało piję, to jest niszczące dla organizmu, ale również może przyczynić się do otyłości. A otyłość jest zarówno niezdrowa, ale również nieestetycznie wygląda (KM_2_24). No nie robię (żeby być szczuplejszą - przyp. aut). Słaba jestem. Wiesz, jakoś nie mam takiej motywacji. Nie mam tej silnej woli, żeby na przykład nie jeść słodyczy. Bo jak mi się zachce, to jem. [...] nie powinno się jeść za dużo, a człowiek z łakomości je słodycze na przykład (KSR_15_62).

Część kobiet wspominała, że nie potrafi prowadzić właściwej diety bądź przejść na dietę odchudzającą. Kobiety mówiły o różnych powodach tego stanu, m.in. o braku silnego charakteru lub lenistwie: „[...] nie podoba mi się, że nigdy nie mogę zeszczupleć, walczę z tym, ale tak na wpół walczę, bo nie mam silnego charakteru, żeby wprowadzać jakieś diety, bo to wszystko krótko trwa. [...] no troszeczkę zeszczupleć 
(bym chciała - przyp. aut.), to czułabym się lepiej" (KSR_13_61). Jak wynika z powyższych wypowiedzi, $w$ omawianym tu aspekcie postawy wobec zdrowia, kobiety zwracały uwagę nie tylko na zdrowie, również na wygląd. Potwierdzenie znajduje tu hipoteza o wpływie kulturowych koncepcji płci zarówno na zdrowie, jak i wygląd - przede wszystkim szczupłość należy do kanonu pożądanych cech kobiety. Wymogi stawiane współczesnemu ciału dotyczą w większym stopniu kobiet. Ocena kobiety dokonuje się właśnie na podstawie jej wyglądu, a o wiele rzadziej na podstawie tego, kim jest i co mówi (Buczkowski 2005: 285). Jak zaznacza Honorata Jakubowska, współcześnie ciało człowieka zostało uwolnione od władzy natury, do końca nie jest jednak obszarem autonomii jednostki, bowiem staje się terenem, który zawłaszcza sobie szeroko rozumiana władza, obecna $\mathrm{w}$ dużej mierze $\mathrm{w}$ systemach produkcji i konsumpcji. Ciało jest konstruktem kulturowym i społecznym, jest przedmiotem kontroli społecznej, która obejmuje różne aspekty (Jakubowska 2009a). Ogromną rolę w upowszechnianiu współczesnych kanonów piękna i urody odgrywają media. W środkach masowego przekazu prezentowane są zwykle szczupłe, wypielęgnowane ciała kobiet, które są wzorcem nie tylko dla młodzieży. Na każdym kroku kobiety nawoływane są do intensywnej pracy nad własną sylwetką. Prasa popularna, telewizyjne spoty reklamowe są pełne wystylizowanych obrazów ciał. Kobiety zachęca się do zmiany wyglądu poprzez kosmetyki, diety, różnego rodzaju treningi czy też operacje plastyczne, informuje się je o tym, co należy robić, aby choć trochę przybliżyć się do ideału (Malinowska, Dzwonkowska-Godula, Garncarek 2012). Jak wynika z analiz Michela Foucaulta, cielesność nie jest czymś naturalnym, przypadkowym. Ciało jest przede wszystkim uwikłane w relacje władzy, jest przedmiotem działania ideologii, służy dyscyplinowaniu jednostki, a także całej populacji (Foucault 1998). Władza tego typu występuje w wielu instytucjach; jednostka doświadcza jej w procesie socjalizacji, w rodzinie, następnie w szkole, pracy, korzystając z opieki medycznej itp. Zdaniem Foucaulta ciało poddane jej kontroli wpisane zostaje bezpośrednio w sferę polityki, gdzie działają na nie stosunki władzy (tamże). Jak wynika $\mathrm{z}$ analizy zebranego materiału, również polskie kobiety nie są w stanie uciec od ograniczeń, które tkwią w ich samych, a które zostały im „podyktowane", np. w procesie socjalizacji.

Kolejne wypowiedzi kobiet dotyczyły szkodzenia własnemu zdrowiu przez stosowanie używek - picie alkoholu lub palenie papierosów. Należy podkreślić, że w tym przypadku wystąpiły różnice pomiędzy kobietami reprezentującymi różne kategorie wiekowe (kwestia ta zostanie omówiona w dalszej części rozdziału). Badane (ogółem) podkreślały, że piją alkohol jedynie okolicznościowo, przy okazji spotkań towarzyskich, 
imprez: „Czasami zdarzy mi się wypić jakieś drinki na spotkaniach ze znajomymi” (KM_9_30); „[...] czasami alkohol, ale to raczej nie w takich ilościach nałogowo, że tak powiem, ale to nawet lekarze zalecają nieduże ilości, więc od czasu do czasu” (KSR_6_48). Nieliczne kobiety wskazywały także na palenie papierosów jako działanie, które negatywnie wpływa na ich zdrowie. Podobnie jak w przypadku picia napojów alkoholowych także tutaj kobiety wspominały o niewielkiej ilości wypalanych papierosów bądź nieregularnym paleniu: „Papierosy, ale to jakby weekendowo” (KM_6_28). Jedna z rozmówczyń, artysta-plastyk, prezentowała przekonanie, że „Nie ma twórczości bez zapalenia papierosa” (KSR_12_6o), dlatego była przekonana, że choć chwilowo nie pali, to do palenia z pewnością powróci. Pozostałe kobiety nie tłumaczyły swoich motywów palenia, wskazywały jedynie, że jest to coś jednoznacznie negatywnego: „Niestety palę papierosy no, [...], także myślę, że najgorsze są te papierosy” (KSR_9_54). Kilka badanych wspomniało również o szkodliwości bycia biernym palaczem, co trudno uznać za antyzdrowotne działanie samej jednostki. Tym bardziej, że niektóre z nich starały się ograniczać wpływ tego negatywnego czynnika na własne zdrowie:

No to bierne palenie chyba mi jednak zaszkodziło, bo mam problemy z drogami oddechowymi w tej chwili, czego wtedy nie było, ale pojawiło się z wiekiem. [...] to znaczy, musiałam, byłam zmuszona, bo w pracy palili, w pokoju, no to trudno było ich [...], poza tym mąż dużo palił, także też byłam zmuszona ten dym wdychać, no i to, to chyba było wbrew mojej woli, że tak powiem i zaszkodziło (KST_9_71).

Wyniki ogólnopolskich badań i sondaży (m.in. CBOS 2010, Diagnoza Społeczna 2011) również pokazują, że mamy do czynienia z mniejszym odsetkiem kobiet wśród spożywających alkohol oraz wśród palaczy. Niewskazywanie przez kobiety na stosowanie substancji psychoaktywnych w takim stopniu, jak czynią to mężczyźni (także w naszym badaniu), można tłumaczyć zróżnicowaną siłą prozdrowotnych presji społecznych wywieranych na kobiety i mężczyzn. W polskim społeczeństwie istnieje mniejsze przyzwolenie dla kobiet palących papierosy czy spożywających wysokoprocentowe napoje alkoholowe. Z obiegowych opinii wynika, że te, które stosują tego typu używki, są uznawane za niekobiece, a palenie negatywnie wpływa zwłaszcza na ich urodę. Należy również dodać, że kobiety częściej niż mężczyźni uświadamiane są w zakresie szkodliwości palenia papierosów i picia alkoholu. Różnego rodzaju poradniki (czasopisma, programy telewizyjne dla kobiet), a także kampanie społeczne informują je o tym, iż palenie wpływa na płodność czy też ryzyko wystąpienia szeregu chorób i stanowi przeszkodę w osiągnieciu ładnego 
wyglądu (Malinowska, Dzwonkowska-Godula, Garncarek 2012: 125). Siła tych presji może skutkować nie tylko unikaniem lub rzadszym stosowaniem różnego rodzaju substancji psychoaktywnych, ale również zatajaniem swoich nałogów.

Badane wspominały ponadto o niepodejmowaniu aktywności fizycznej jako działaniu antyzdrowotnym: „Niestety teraz nie uprawiam żadnych sportów oprócz spacerów [...]. Zaobserwowałam, że bardzo dużo ludzi biega po osiedlu, w ogóle w mieście. Sporo na rowerze jeździ. Ludzie dbają o siebie, chcą być piękni i zadbani. Niby też bym tak chciała, ale jakoś nie mogę się przełamać, nie mam motywacji, czy [...] sama już nie wiem dlaczego. Takie zamknięte koło" (KM_13_34). Niepodejmowanie aktywności ruchowej tłumaczono m.in. brakiem czasu lub sił w związku z łączeniem roli zawodowej i roli matki oraz siedzącym trybem pracy:

Może to wymówka, ale nie mam czasu (aby dbać o swoje zdrowie inaczej niż staranie się jeść zdrowo i regularnie - przyp. aut). Niby mogę ćwiczyć $\mathrm{w}$ domu, ale często jest tak, że o godzinie dziewiątej już zasypiam razem ze starszą córką, a jeszcze mam dużo obowiązków typowo domowych, przy dwójce dzieci mam codziennie stertę prania, stertę naczyń i gotowania i czasami mi się nie chcę, nie mam siły. Też nie mam czasu, bo z mężem wymieniamy się dziećmi około godziny wpół do siódmej, kiedy jest już czas na kolację i kiedy dzieci idą spać. Przychodzę z pracy i na drugi etat pracuję (KSR_1_38). $\mathrm{W}$ tej chwili z kręgosłupem mam problem, ale to też przez to, że dużo siedzę przy komputerze, przy biurku, nie taka postawa i sobie pogorszyłam na własne życzenie (KSR_8_53).

Na brak aktywności fizycznej wskazywały przede wszystkim kobiety będące $\mathrm{w}$ średnim wieku i kobiety stare. Ten brak aktywności można tłumaczyć podwójnym obciążeniem kobiet obowiązkami. Z jednej strony pełnią one role rodzinne, $\mathrm{z}$ drugiej związane $\mathrm{z}$ zawodową sferą życia. Czasami pomiędzy nimi brakuje już czasu bądź siły na dodatkową aktywność fizyczną, nawet jeśli posiada się świadomość pozytywnego jej wpływu na stan zdrowia jednostki. Kobiety stare zaś nie mają nawyku dbania o zdrowie w ten sposób. Część z nich nie uprawia żadnej aktywności fizycznej także z powodu różnego rodzaju dolegliwości zdrowotnych.

Kolejnym wymienianym przez kobiety działaniem wpływającym negatywnie na ich własne zdrowie był brak odpowiedniej ilości snu. Badane mówiły m.in. o zbytnim zaangażowaniu w pracę, przepracowywaniu się, które skutkuje zmęczeniem: „Czasem długa praca, po 10 godzin, na pewno to nie jest korzystne tyle pracować i krótki sen, krótko śpię (KM_7_28)”; „Może za późno chodzę spać. Ale nigdy wyrobić nie 
mogę. Wstaję przed 7, jak trzeba to wcześniej” (KST_6_69). Część badanych wspomniała, że wieczorami spędza czas na czytaniu lub oglądaniu telewizji, w związku z tymi czynnościami przeznacza zbyt mało czasu na spanie: „Może to jest szkodliwe, że ja długo w nocy siedzę. Powinnam na przykład przed dwunastą iść spać, no ale jak się zabiorę za jakąś książkę i jest ciekawa, no to nie mogę odłożyć. A jak jest ładny film, to też nie mogę, obejrzę" (KST_3_65). Jedna z kobiet przyznała, że jej zmęczenie wynika także z nocnego imprezowania i braku umiejętności odpoczynku i regeneracji organizmu:

Sporo imprezuję, mam stresujący i wyczerpujący tryb życia, mam problem z odpoczynkiem, jak mam czas wolny i sobie zaplanuję odpoczynek, to się okazuje, że to jest aktywny odpoczynek i jak sobie to wszystko podsumowałam, to nie ma takiego czasu, żeby usiąść i nic nie robić i się przestraszyłam, czy wszystko jest ok, szczególnie, że po długim, trudnym tygodniu jak sobie planuję, że sobie poleżę, to jakoś tak wychodzi, że idę na imprezę i znowu tańczę całą noc i jestem coraz bardziej wyczerpana (KM_5_28).

Jak wynika z powyższych cytatów, problem braku odpowiedniej ilości snu uzależniony jest od wieku respondentki. Występują tutaj różnice generacyjne, a wraz z nimi realizowanie specyficznych stylów życia, w tym sposobów spędzania wolnego czasu.

Do zachowań antyzdrowotnych kobiety zaliczyły także stresujące sytuacje. Wyrażały przekonanie o szkodliwym wpływie stresu związanego przede wszystkim z zaangażowaniem w pracę zawodową. Wspominały także o specyfice współczesnego życia, które stawia jednostkę przed wieloma wyzwaniami, zmuszając ją niejednokrotnie do poszukiwania nowych sposobów radzenia sobie z różnymi problemami: „Stresuję się czasami, zdarzało się i że nie spałam, bo coś tam, nie wiem, bo termin goni, bo szefostwo naciska albo są jakieś nieprzyjemne sytuacje” (KM_8_29). Część rozmówczyń wskazywała na wpływ stresu wynikającego z łączenia ról rodzinnych i zawodowych jako nie do końca celowe działanie, ale bez wątpienia niekorzystnie wpływające na ich zdrowie:

Staram się o siebie dbać na tyle, na ile daję radę. No wiadomo, że nie jest tak, że człowiek się niczym nie przejmuje, bo co rusz, to są jakieś kłopoty, w rodzinie np., ale staram się jakoś tak bardziej racjonalnie do tego wszystkiego podchodzić. [...] wcześniej, bardziej się przejmowałam, stresowałam. To niestety odbijało się na zdrowiu, przede wszystkim psychicznym, niestety (KSR_4_45).

Badane częściej niż mężczyźni wskazywały na odczuwanie stresu. Tę deklarację można tłumaczyć faktem łączenia przez nie pracy zawodowej z życiem rodzinnym (to kobiety przede wszystkim odpowiedzialne 
są za opiekę nad dziećmi i pracę w gospodarstwie domowym (Titkow, Duch-Krzystoszek, Budrowska 2004). Konieczność radzenia sobie przez kobiety z licznymi obowiązkami (domowymi, rodzinnymi, zawodowymi) czasami przerasta, w ich odczuciu, siły i możliwości. Jak zaznaczają Claire Renzetti i Daniel Curran, współczesne kobiety nadal socjalizowane są głównie do tradycyjnych ról społecznych. Uspołecznianie kobiet często prowadzi do ich pasywnych reakcji w sytuacji stresu, natomiast u mężczyzn odwrotnie - wzmacnia się zachowania asertywne w sytuacjach stresogennych. Jak zaznaczają autorzy, doświadczające stresu kobiety częściej popadną w depresję, natomiast mężczyźni będą próbowali rozwiązać problemy poprzez podjęcie konkretnych działań (Renzetti, Curran 2005). Z analiz A. Ostrowskiej wynika również, że:

w przypadku kobiet wykonujących pracę zawodową w grę wchodzi także nieadekwatność płacy za pracę (niższa płaca kobiet w porównaniu z płacami mężczyzn na analogicznych stanowiskach) i niedoceniana praca domowa. Istnieją publikacje (Garmanikov et al. 1983), które w sytuacji tej upatrują przyczyn częstszego niż wśród mężczyzn występowania depresji wśród kobiet. Traktuje się w nich niektóre postacie depresji jako zmedykalizowane zjawisko społeczne. Kobiety częściej ulegają depresji, ponieważ mają ku temu powody. Są one związane głównie z niekorzystnym układem ról społecznych i strukturą szans w społeczeństwie (Ostrowska 2006: 120).

Analizując tę kwestię, autorka cytuje badania Schwartza (1991), który zaznacza, że

to raczej zespół oczekiwań społecznych, a nie aktualnie pełnione role, stanowią podatny grunt dla powstawania depresji. Oczekiwania te - wywodzące się z kultury patriarchalnej - w sposób spójny łączą takie cechy, jak: dyspozycja do podporządkowania się, zależność, posłuszeństwo, zewnętrzną sterowność, tłumienie negatywnych emocji. Cechy te, w mniejszym lub większym stopniu, są elementami socjalizacji do roli kobiety, wpajanymi już we wczesnym dzieciństwie. W modelu takim jest mało miejsca na realizację własnych dążeń i pragnień czy ogólnie rozumianą samorealizację; sukcesy kobiet są tu raczej mierzone osiągnięciami innych - męża czy dzieci, dla których zgodnie z panującymi oczekiwaniami powinny się one "poświęcić« (Schwartz 1991, za Ostrowska 2006: 120).

Następnymi w kolejności zachowaniami niekorzystnymi dla zdrowia wymienianymi przez kobiety, które wzięły udział w naszym badaniu, były: niewykonywanie badań profilaktycznych oraz lekceważenie objawów chorobowych: „To, że lekceważę różne objawy, które wynikają gdzieś tam w funkcjonowaniu, gdzie tam mój organizm je przejawia” (KM_4_27). Część wypowiadających się przyznała, że nie robi badań 
profilaktycznych tak często jak należy lub robi je tylko w ograniczonym zakresie - najczęściej są to profilaktyczne badania ginekologiczne. Powody niewykonywania badań profilaktycznych na jakie wskazywały kobiety to m.in. strach przed bólem (np. w czasie badań mammograficznych - KSR_8_53), „skrajna głupota” (KSR_9_54) lub nieodczuwanie potrzeby badań profilaktycznych (KSR_4_45).

Powinnam iść na mammografię, dostaję non stop, że mnie zapraszają. $\mathrm{Z}$ jednej strony bardzo bym chciała sprawdzić, czy jest wszystko w porządku. (Nie idę - przyp. aut.), bo to boli i nie chcę. Ja wiem, że ból jest rzeczą osobistą, jednego boli, drugiego nie boli, ale jakoś tak sobie zakodowałam, że będzie mnie to bolało. Wiem, że powinnam to zrobić no i myślę, że jak jeszcze ze 2 zaproszenia dostanę, to pójdę (KSR_8_53). Taki racjonalny wyrzut sumienia to jest ten, że kiedyś powinnam iść do lekarza i się przebadać. Bo odkąd urodziłam dzieci nie byłam u lekarza [...] (KSR_9_54). A badanie krwi, cholesterol, to już 10 lat nie robię. [...] no trochę z nygustwa, a to kiedy indziej, i to się tak odwleka. [...] no nie, nie dokucza mi coś, co by mogło mi zaszkodzić. No jak byłam przeziębiona, no i zapalenie oskrzeli miałam, to i poszłam zrobić prześwietlenie płuc i chodziłam do lekarza, no bo byłam bardzo chora. A jak jestem tyle o ile, to mówię - później i później, bo zawsze coś jest do zrobienia innego, a to w domu [...]. To tak lecą miesiąc, miesiące (KST_1_64).

Jak wynika z powyższych wypowiedzi, niektóre kobiety lekceważą kwestię badań profilaktycznych, ponieważ jeszcze nie odczuwają większych dolegliwości zdrowotnych (zwłaszcza kobiety młode), z lenistwa, braku czasu, strachu przed zdiagnozowaniem ew. choroby (zwłaszcza kobiety w średnim wieku). W większości były one jednak świadome znaczenia profilaktyki dla zdrowia człowieka. Częściej również niż mężczyźni wskazywały na brak profilaktyki jako zachowanie antyzdrowotne. Były również bardziej refleksyjne i krytyczne, jeśli chodzi o działania szkodzące zdrowiu niż mężczyźni.

Pojedyncze wypowiedzi dotyczyły przepracowywania się jako działania, które niekorzystnie wpływa na zdrowie:

Może te ciężkie roboty jakie podejmuje [...]. No ogródek prawda kopany, nieraz coś piłowane jest. Szczególnie na te ręce, robię różne rzeczy, remonty kiedyś, przestawianie gratów, jeszcze jedną wersalkę przestawiałam (KST_6_69). Praca, to zdecydowanie (za dużo pracuję, jeszcze zawodowo). To że się nie ruszam, że jestem leniwa, że nie ćwiczę niczego, wiem, że jak na wakacjach, kiedyś miałam taki zwyczaj, że chodziłam dużo, teraz trochę mniej, w związku z pracą, bo wracam trochę później i jest mi ciężko się zebrać, żeby gdzieś tam lecieć, ale lepiej się czuję jak się ruszam. Za mało się na pewno ruszam. To najbardziej wynika ze zmęczenia. Bo na wakacjach to chodzę kilometry, jak mam czas i jestem wypoczęta (KST_7_70). 
Jedna $\mathrm{z}$ kobiet wspomniała o niekorzystaniu z zalecanych zwolnień lekarskich jako zachowaniu antyzdrowotnym: „[...] nie dbam o zdrowie, bo nie idę na badania jak powinnam, lekarz mi mówi, że powinnam iść na zwolnienie, nie biorę tego zwolnienia. [...] no bo muszę iść do pracy. Jakoś tak no nie dbam, [...] no troszkę robię, ale mówię, to robię jak już tak czuję, że nie mam siły i że dotarłam do tej granicy. [...] tak, że dalej po prostu tego już się nie da lekceważyć" (KSR_8_53).

Nieliczne rozmówczynie wskazały na brak zachowań szkodzących ich zdrowiu, bądź wyeliminowanie antyzdrowotnych działań ze swojego życia (poza okolicznościowym spożywaniem alkoholu): „Ale, praktycznie oprócz tego (picia alkoholu okolicznościowo - przyp. aut.), no to wyeliminowałam wszystkie takie rzeczy, które wiem, że na pewno są szkodliwe” (KM_12_34); „Raczej unikam takich rzeczy. To nie jem, jak mi coś szkodzi. To już mam tak zakodowane w swojej głowie, że wiem, co mogę, a czego nie mogę" (KST_13_85).

Jeśli chodzi o mężczyzn, którzy wzięli udział w naszym badaniu, to podobnie jak u kobiet najczęściej wskazywano na niewłaściwe odżywanie się jako zachowanie szkodzące zdrowiu. Mężczyźni mówili o stosowaniu nieodpowiedniej diety, objadaniu się, zwłaszcza ciężkostrawnymi produktami - zbyt tłustymi i smażonymi, spożywaniu jedzenia typu fast food:

Lubię polską kuchnię, żeby podsmażyć, lubię takie smażone, wiem, że jest niezdrowe, ale lubię, jedzenie to jest moja największa słabość (MM_2_22). Niekorzystne to łakomstwo, lubię słodkie, lubię rzeczy dobre i tłuste, które no tak jak mówię, typowa polska kuchnia, kapusta, jakieś tłuste żeberka czy golonka, aczkolwiek golonki samo jako takiej to niespecjalnie, ale dobra jakaś kiełbasa, czyli tłustawa raczej. [...] no tak dieta niekorzystna (MST_11_71). surową kiełbasę [...]. No tak, taki występek to raz w tygodniu mi się zdarzy (MST_12_72).

$\mathrm{Z}$ analizy uzyskanych wypowiedzi wynika, że mężczyźni zdają się mniej zważać na kwestie dietetyki niż kobiety. Pomimo tego, że mają świadomość negatywnego wpływu niewłaściwego odżywiania się na swoje zdrowie, to nie rezygnują z produktów wysokokalorycznych i tłustych: „[...] powinienem być trochę na diecie, bo trochę cukier za wysoki, ale lubię sobie golonkę zjeść, dobre żeberka, dobre piwo wypić, dobry koniaczek itd. [...]" (MST_1_63). Warto w tym miejscu zwrócić uwagę na to, jak mężczyźni wyjaśniają skłonność do jedzenia fast foodów. Jeden z panów wspomniał o przeczytanym w Internecie artykule przekonującym do tego, że jakość mięsa w pewnej sieci fast foodowej jest bardzo wysoka, o czym ma świadczyć dobry smak (MSR_1_38). Inny badany dostrzegł zależność między skłonnością do jedzenia fast foodów 
a wiekiem, twierdząc, że jego pokolenie jest szczególnie narażone na uległość wobec zachęt sieci fast foodowych, postrzeganych jako „synonim luksusu z Zachodu”, który pojawił się w Polsce po 89 roku, czyli w czasach, gdy miał 12 lat:

Albo objadam się fast foodami, wszystkie »bigmacki«, »whoopery« nie są mi obce, wręcz przeciwnie. [...] chociaż, jeśli chodzi o fast foody, to ten pierwszy etap u siebie to, że tak powiem przejadłem. Już to nie jest taką atrakcją, jak kiedyś to jedzenie. Chociaż troszeczkę jest to zdeterminowane datą urodzenia, bo do 1989 roku nie było takich rzeczy w Polsce, to był synonim luksusu. Pierwszy McDonald został otwarty w 1994 roku na Placu Wolności. Pamiętam jak byłem w 1991 roku w Budapeszcie, te kolory tak biły po oczach, że ja sobie wziąłem wszystko, co na tej tacy zostało. Moje pokolenie miało tego deficyt, to się nam kojarzyło z luksusem, Zachodem, innym życiem. Trochę już się to nam przejadło, aczkolwiek lubię czasami ugryźć podwójnego »Whoopera«. [...] obżeranie się, słodycze, fast foody (MSR_3_40).

Mężczyźni wspominali również o niespożywaniu domowego jedzenia jako działaniu antyzdrowotnym. Zdaniem badanych domowe jedzenie jest zdrowsze od tego, które spożywa się na mieście: „No mieszkając na studiach w akademiku też, no żywienie nie jest takie jak domowe, więc no na pewno to jakoś wpływa na układ pokarmowy, duże ilości kawy czasem" (MM_1_21). Mówili również o niejedzeniu owoców i warzyw jako wpływających negatywnie na zdrowie:

To znaczy myślę, że odżywiam się tak sobie. [...] ale ja nie odczuwam żadnych dolegliwości związanych z moim odżywianiem się. [...] po prostu moja dieta jest uboga w niektóre elementy, które są normą w dietach innych ludzi. Czyli na przykład pewne owoce lub warzywa [...]. To znaczy inni tak uważają, że ja się źle odżywiam, a ja myślę, że moja dieta jest odpowiednia. Może faktycznie powinienem spożywać więcej pewnych produktów, ale tragedii nie ma. Kobieta moja czepia się, że moja dieta jest [...] niewzbogacona o owoce i warzywa. Uważa, że nieregularnie spożywam posiłki. Faktycznie tak jest, ale osobiście nie widzę w tym problemu (MM_3_22).

Część mężczyzn zwróciła również uwagę na problem nieregularnego spożywania jedzenia jako działania, które szkodzi ich zdrowiu:

Ja myślę, że odżywiam się dobrze, natomiast za dużo. Ja powiem, że to jest dobre jedzenie, zdrowe, że tak powiem, natomiast zdecydowanie za dużo i nieregularnie. W związku $\mathrm{z}$ uprawianym zawodem jest tak, że zaczynam pierwsze żywienie po 20. Czyli 12 czy 13 godzin absolutnie bez niczego (MSR_12_58). Wraca się bardzo późno i to jedzenie wieczorne. Głód robi swoje (MSR_14_61). 
Do nieodpowiedniego odżywania zaliczano także spożywanie zbyt dużych ilości słodyczy. Na to działanie antyzdrowotne, podobnie jak w przypadku kobiet, wskazywało większość naszych rozmówców. Jedzenie słodyczy mężczyźni wyjaśniali słabą wolą, uleganiem takim pokusom jak spotkania okolicznościowe z suto zastawionym stołem bądź, że mają do słodyczy ogromną słabość:

Jem snickersy. [...] słodycze, mam słabość do snickersów (MM_2_22). Te słodycze. Raz się żyje. Myślę, że słodycze nie są takim zagrożeniem jak nikotyna czy inne rzeczy (MM_12_32). Myślę że każdy człowiek, nie jest w stanie uniknąć pokusy i może wpłynąć niekorzystnie na swój organizm. [...] no pokusy są w koło. [...] myślę, że (pokusy, którym ja ulegam, to - przyp. aut.) słodycze, niesprzyjający jest alkohol, przyjęcia, jakieś spotkania rodzinne, okolicznościowe gdzie jest wiadomo ustawiony suto stół. To są pokusy, które mogą wpłynąć niekorzystnie na mój stan zdrowia (MSR_2_39).

Niektórzy zaś wspominali o rezygnacji z palenia papierosów, co wiązało się ze spożywaniem większej ilości słodyczy: „Słodycze. Nadmiar słodyczy, nie można się od tego uwolnić. Rzuciłem fajki, także to też dodatkowo wzmogło" (MM_13_32). Powyższe wypowiedzi na temat sposobów odżywiania się mężczyzn wpisują się w tradycyjny model męskiego żywienia, polegający na spożywaniu obfitych, wysokokalorycznych posiłków, a także na większe społeczne przyzwolenie na folgowanie swoim pokusom $\mathrm{w}$ zakresie jedzenia (nie tylko $\mathrm{w}$ domu, ale również podczas przyjęć, spotkań towarzyskich poza domem, w restauracjach). Jak zaznacza A. Ostrowska, w naszej kulturze, istnieją zróżnicowane oczekiwania co do sposobu odżywiania się mężczyzn i kobiet - np. ulubionych potraw. Wdrożenie tych oczekiwań kształtuje odpowiednio gusty i wybory konsumpcyjne obu płci (Ostrowska 2006: 117).

Do wymienianych przez mężczyzn (bez względu na wiek) działań antyzdrowotnych należało także picie alkoholu oraz palenie papierosów. W odniesieniu do spożywania napojów alkoholowych mężczyźni zaznaczali, że piją je okazjonalnie oraz, że preferują spożywanie trunków w towarzystwie. $Z$ wypowiedzi badanych wynika również, że spożywają oni napoje alkoholowe częściej i w większych ilościach niż kobiety:

Jest tak, w ogóle nie powinno się alkoholu pić. Mówię tutaj o piwie czy o wódce. Czasami zdarza się wypić, a jest to niezdrowe dla organizmu. [...] piję od czasu do czasu, jeżeli na przykład ktoś [...], nie mam czegoś takiego, że muszę się napić, ale jeżeli mam się z kimś napić, to pije tylko z kimś. Nigdy sam. [...] wydaje mi się, że piję alkohol raz w tygodniu. [...] jeżeli wyjeżdżam na działkę, to jest to obowiązkowo wódka, bo babcia niestety nie popuści. Musi czasami polać $\mathrm{i}$ to nie może być jeden kieliszek, a musi być $\mathrm{z} 4$ albo 
i więcej. Chyba że nie jedziemy na działkę, no to czasami jest to w weekend jakiś piwo czy 2 albo jeżeli gdzieś wychodzimy z taką paczką kolegów, to wtedy zależy, co to jest. Po prostu czasami mam ochotę się napić i piję, a czasami po prostu nie mam i nie piję tydzień lub dwa tygodnie. I tyle (MM_4_24). Może nie nadużywam alkoholu, ale być może za często go piję, szczególnie jeśli chodzi o piwo, które jest absolutnie alkoholem, który jest najbardziej szkodliwy (MM_7_28). [...] lubię czasem sobie wypić piwo, a to nie za dobre jest przy nadciśnieniu. Ale nie pije codziennie, ale od czasu do czasu lubię (MSR_6_47).

Część mężczyzn zastanawiała się nawet, czy rzeczywiście spożywanie alkoholu jest niezdrowe: „No i czasami spożywam alkohol. No ale ostatnio słyszy się, że to nawet zdrowe. Więc sam nie wiem, do czego to zaliczyć (MM_3_22); „No, używki, no to czasem zdarzy się właśnie, mieszkając w akademiku, czy w ogóle być w tym wieku, bo to jest normalne" (MM_1_21).

Jeśli chodzi o palenie papierosów, wśród wypowiadających się mężczyzn byli i nałogowi palacze i osoby palące okazjonalnie, na imprezach:

Oprócz palenia czy piwka chyba nie podejmuję innych działań mogących źle wpływać na moje zdrowie - przyp. aut.) (MSR_7_49). Palę sobie, w sumie to popalam, dużo nie palę, tam do paczki dziennie, to chyba nie jest dużo. [...] ale to też. Jak człowiek jest w pracy, to bardziej chodzi chyba o to, żeby mieć coś w ręku niż bardziej o sam fakt palenia, bo jak człowiek pracuje, to jakoś nie mam takiego parcia, jak to się mówi, że muszę o, w danej chwili iść i muszę zapalić, biec już teraz. Bardziej tak w czasie wolnym, jakby brakowało zajęć, to nie wiem dlaczego tak zastępuję sobie tą jakby to powiedzieć - aktywność tym papierosem (MM_8_29).

Jeden z palaczy wspomniał, że zamienił tradycyjne papierosy na papierosa elektronicznego, który, w jego przekonaniu, nie jest szkodliwy, jednak chętnie uwolniłby się od tego nałogu: „(Palenie zamieniłem na przyp. aut.) na elektroniczne, ekologiczne [...]. Ja to traktuję jako inhalację, aczkolwiek no uwolniłbym się od tego też. Normalne fajki rzuciłem” (MM_13_32). Część badanych wspomniała, że paliła papierosy przez większość swojego życia, ale zrezygnowała z nałogu i obecnie nie pali papierosów: „No, jak byłem młodszy to i alkohol, prawda, i papierosy. To było na pewno przeciwko zdrowiu. Teraz już coraz częściej, od wielu lat już nie, no tak było przez 30, 40 lat [...]” (MST_2_63). Jeden z mężczyzn wspomniał także o byciu biernym palaczem, które jego zdaniem może szkodzić zdrowiu: „[...] jeśli mam kontakt z dymem tytoniowym, to jest to kontakt [...], który jest w knajpie albo u kogoś w domu” (MSR_4_40). Inny z rozmówców, mówiąc o stosowaniu używek, nawiązał do spożywania dużej ilości kawy jako działania, które może wpływać na jego stan zdrowia: „Czy kawa [...], faktycznie mógłbym wskazać ewentualnie kawę, 
która może być takim elementem problematycznym. [...] no potrafię wypić 5-7 kaw dziennie" (MSR_1_38).

Jak już wspomniano, wymienione używki częściej stosują mężczyźni niż kobiety. W naszej kulturze papieros nadal stanowi symbol męskości, spożywanie alkoholu przy różnego rodzaju okazjach (imprezy, przyjęcia, wesela) jest normą, a odmówienie wypicia za zdrowie jubilata bądź młodej pary może zostać uznane za niestosowne do okoliczności zachowanie. W patriarchalnej kulturze męskość od wieków kojarzona jest z używaniem wspomnianych substancji psychoaktywnych, tj. papierosy czy wysokoprocentowe alkohole, a także istnieje większe przyzwolenie dla mężczyzn je stosujących (m.in. Ostrowska 2006, Królikowska 2011). Warto w tym miejscu zwrócić również uwagę na zachowania, które mężczyźni uznają za prozdrowotne. Napoje zawierające alkohol, tj. piwo bądź nalewki, często występują w roli lekarstwa na różnego rodzaju dolegliwości zdrowotne:

Jak pracowałem, gdzieś w młynie, jak byłem przeziębiony, to nie chodziłem do lekarza, ja się wypociłem w domu, ze trzy razy zmieniłem koszule i byłem zdrowy. [...] poszedłem do domu, do mamy, to mi dała polopirynę, to mówię do mamy »dwie mi daj«, i szklankę bimbru wypiłem. I dwie godziny pod pierzyną, cały przykryty przeleżałem, dwa razy się przebrałem, po tych dwóch godzinach kaszel mi minął. [...] teraz, jak się przeziębię, to biorę piwo, sok malinowy do tego grzeję i to sobie wypije, wygrzeje się, wypocę się i mi starczy (MST_6_66).

Mężczyźni wspominali także o braku aktywności fizycznej/ruchu, co niekorzystnie odbija się na ich zdrowiu: „Ostatnio mało się ruszam” (MM_2_22). Winą za taki stan rzeczy obarczali przede wszystkim rodzaj pracy i siedzący tryb życia: „No może za mało się ruszam, powinienem więcej z pewnością, spędzam za dużo czasu w tej samej pozycji, siedząc przy komputerze czy chociażby nad książkami”" (MM_1_21); jak również zbyt częste korzystanie $\mathrm{z}$ samochodu, którym jeżdżą zamiast chodzić: „Nie raz tego ruchu jest za mało niż bym oczekiwał, tak. Dzisiaj przyjechałem tutaj samochodem, chociaż mogłem się przejść" (MSR_3_40); własne lenistwo, brak samozaparcia czy determinacji, dobrej organizacji swojego czasu oraz zmęczenie:

Pewnie mógłbym więcej ćwiczyć niż ćwiczę, pewnie mógłbym więcej jeździć rowerem, więcej pływać. Nie robię tego. Szczerze mówiąc, pewnie jestem za leniwy, bo nie powiem, że mam za dużo pracy, to jest tylko kwestia organizacji. Jeśli mamy samozaparcie, to możemy sobie zawsze zorganizować czas tak, żeby podołać wszystkiemu, ale widzę pewne ograniczenia, które są we mnie i czasami bywam zmęczony. I jeżeli nie muszę, to nie staram się pokonywać tego zmęczenia za wszelką cenę (MSR_10_56). 
Cześć rozmówców tłumaczyła brak aktywności fizycznej słabym stanem zdrowia, jak również złą sytuację ekonomiczną, które ich zdaniem uniemożliwiają aktywność fizyczną:

Ruch, poprzez moje ograniczenia, spadł do no, do zera prawie. Do tego, co jest koniecznością. Jeśli chodzi o uprawianie czegokolwiek, no to wykluczone jest w moim przypadku już teraz całkowicie. A tryb życia jest taki, że urąga w ogóle wszelkim normom. [...] ekonomia, ekonomia. [...] może gdybym się zoperował, gdybym mógł wrócić do czynnego życia takiego jak kiedyś, gdybym mógł żyć zdrowiej, bo mógłbym się ruszać, to bym mógł zdrowszy tryb życia prowadzić. A w tej chwili jedno, łańcuszek cały powoduje [...] (MSR_11_57).

Należy w tym miejscu podkreślić, że w patriarchalnej koncepcji męskości aktywność zawodowa i pozycja materialna są wyznacznikiem życiowego sukcesu mężczyzny. Wynika z nich nie tylko konieczność zapewnienia swojej rodzinie odpowiednich warunków życia, ale także wpływa ona na podejście mężczyzn do zachowań zdrowotnych. Z analizy zebranych danych, omówionych w poprzednich rozdziałach, wynika, że mężczyźni częściej niż kobiety zwracali uwagę na ekonomiczne uwarunkowania swoich działań zdrowotnych.

Następnym w kolejności działaniem wpływającym negatywnie na stan zdrowia było przepracowywanie się. Badani nawiązywali również do wykonywanych przez siebie zawodów i niekorzystnego wpływu pracy wykonywanej w określonych warunkach na ich zdrowie: „Za dużo pracuję ale muszę. [...] raczej nie podejmuję takich działań poza nadmierną pracą” (MSR_10_56); „[...] przekraczanie możliwości fizycznych, których nie powinienem przekraczać (MST_10_71); „[...] tak jak ja, jak mi mówili, że [...] człowiek zaczynał pracować w swoim zawodzie, że piętnaście lat i można już emeryturę [...] (MST_3_63). Jak wynika z powyższych cytatów, badani mają świadomość wpływu przepracowywania się na zdrowie, jednak można było odnieść wrażenie, że są pogodzeni z tą sytuacją i aktywność zawodowa, nawet $\mathrm{w}$ nadmiarze, jest czymś oczywistym dla mężczyzn. Praca zawodowa stanowi kluczową płaszczyznę aktywności mężczyzny i stanowi istotny element patriarchalnej koncepcji męskości. Wypowiedzi respondentów, nie tylko w omawianym tu aspekcie postawy, potwierdzają tę zależność. Jak wynika $\mathrm{z}$ analiz poczynionych m.in. przez A. Ostrowską, mężczyźni poświęcają znacznie więcej czasu na aktywność zawodową niż kobiety. Źródła tego faktu badaczka upatruje m.in. w pełnionych przez kobiety i mężczyzn rolach społecznych, odmiennych wzorach zachowania, procesach socjalizacji, stylach życia, a także warunkach i rodzaju wykonywanej pracy (Ostrowska 2006: 124). 
Badani zadeklarowali ponadto nieodpowiednią długość snu jako działanie, które szkodzi ich zdrowiu. Cześć z nich mówiła o „zarywaniu nocy” ze względu na długie godziny spędzane przed komputerem:

Niewyspanie się, a nieraz takie coś było, że wolałem wstać wcześniej, żeby pograć (na komputerze - przyp. aut.) (MM_9_30). Myślę, że dużo godzin przed komputerem powoduje pogorszenie mojego wzroku i to wszystko, nie widzę innych złych czynników, bo staram się faktycznie ograniczać złe czynniki (MM_15_37). [...] ja chodzę bardzo późno spać, około godziny 24, 1 czy 2 w nocy, a wstaję o 6.30 (MSR_9_54).

Równie często mężczyźni deklarowali lekceważenie objawów chorobowych i niewykonywanie badań profilaktycznych oraz unikanie wizyt lekarskich:

Brak wizyt u lekarza w celu wyeliminowania bieżących dolegliwości (MM_13_32). Nie (robię badań kontrolnych - przyp. aut.). [...] no kiedyś, w pracy, za komuny, to były, tzn. okresowe robiłem, ale teraz nie, nie mam takiej potrzeby (MSR_13_6o). Jakbyśmy zrobili listę, co należałoby, a czego nie, to podejrzewam, że w tej grupie »czego nie należałoby«, to miałbym wszystkie pozycje zaznaczone, natomiast »co by należało to« [...], regularne chodzenie do lekarzy na badanie się, sprawdzanie poziomu cholesterolu i innych tych rzeczy - niczego tego nie robię [...] (MSR_9_54).

Mężczyźni zwrócili także uwagę na brak wytrwałości w dbaniu o zdrowie (chodzeniu do lekarza, zdobywaniu skierowań na badania itp.), ponieważ, jak zauważył jeden z rozmówców, wytrwałość w dbaniu o zdrowie jest uzależniona od płci. Wśród badanych kobiet, nie odnotowano wypowiedzi w tej kategorii. Aby pokazać szerszy kontekst, poniżej zamieszczono dłuższy fragment wypowiedzi mężczyzny:

Ale pierwsza sprawa to jest badanie, bo jak jest badanie, to może być jakaś diagnoza, wychwycenie jakiejś choroby. Najlepiej ją wychwycić we wczesnym stadium, bo wtedy jest większa szansa, że się wyleczymy. Ale, kurczę, jak nie będzie tego dostępu do tego badania łatwego, no to nie ma diagnozy. Nie ma wczesnego leczenia. No i koniec i potem [...], kobiety może są bardziej wytrwałe w tym wszystkim [...]. No walczą, jakoś potrafią się przebić i jest taka sytuacja, że kobiety chorują, a mężczyźni umierają [śmiech] (MSR_11_57).

Jak wynika z analizy wypowiedzi kobiet, są one przyzwyczajone do tego typu kontaktów - korzystanie z porad lekarskich i wykonywanie badań profilaktycznych nie jest dla nich tak problematyczne jak dla mężczyzn. Warto tu zwrócić uwagę na stale pokutujący stereotyp, zgodnie z którym mężczyzna powinien być niezniszczalny i postępować zgodnie 
ze starym powiedzeniem „prawdziwy mężczyzna nigdy nie płacze”. Paradoks tradycyjnego wzorca męskości polega również na tym, że mężczyzna „nie może” chorować, ale „nie może” też zadbać o zdrowie. Potwierdzają go również autorzy raportu Zdrowie - męska rzecz opracowanego pod patronatem Narodowego Instytutu Zdrowia Publicznego - Państwowego Zakładu Higieny (Raport Siemensa 2012).

Pojedyncze wypowiedzi mężczyzn dotyczyły braku działań antyzdrowotnych. Kilku badanych wspomniało, że stara się nie szkodzić swojemu zdrowiu zwracając uwagę na rodzaj spożywanych produktów: „To znaczy świadomie to na pewno nie, a nieświadomie to może. Jakieś w sposób taki dla mnie nieświadomy. [...] nie no, oczywiście, że tak, że to, co miało mi zaszkodzić, to po prostu nie jadłem" (MST_13_77). Jeden z mężczyzn zaznaczył, że nie wykonuje żadnych działań, które mogłyby szkodzić jego zdrowiu: „No nie. Chyba nie. Teraz to chyba nie. Raczej staramy się z żoną dbać o zdrowie. [...] no raczej zdrowo się trzymamy” (MST_8_70). W swojej wypowiedzi odwoływał się jednak do działań realizowanych wspólnie z żoną (odpowiadając na pytanie o działania prozdrowotne również nawiązywał do różnego rodzaju czynności, którymi zajmuje się jego żona, a które pozytywnie wpływają na zdrowie respondenta). Jak już wspomniano, w poprzednim podrozdziale zachowania prozdrowotne mężczyzn są wynikiem działań ich żon bądź córek, które zajmują się zdrowiem swoich mężów i/lub ojców: „Ona dbała. Dbała o dzieci, no i o mnie. O dom bardzo żona dba. Widzę, że to ma dobre skutki” (MST_8_70).

Jeden $z$ młodych mężczyzn również wspomniał, że nie robi nic przeciwko swojemu zdrowiu. Jednak zdrowie łączył przede wszystkim z kondycją fizyczną i miał na myśli działania skierowane właśnie na nią. Jak już wspomniano we wcześniejszych podrozdziałach, mężczyźni, zwłaszcza młodzi, utożsamiają dbanie o zdrowie właśnie z dbaniem o kondycję fizyczną. Poniższy cytat doskonale ukazuje tę zależność:

Dobrze wykonuję ćwiczenia - z pulsometrem, więc chyba jest wszystko ok. Obecnie nie mogę się dopatrzeć, że robię coś źle. Mam do czynienia z osobami, które są bardzo mocno zakorzenione w sporcie i uważają, że na niewłaściwym tempie trenuje, na tętnie, z pulsometrem teraz biegam. [...] kiedyś dużo niewłaściwych rzeczy, nie raz się napiłem, przesadziłem, papierocha, nie tylko papierocha się zapaliło, nie zawsze się zdrowo żyło. Ale obecnie trudno mi powiedzieć, że robię coś złego i niewłaściwego zdrowiu mojemu (MM_10_31).

Gdy w analizie wypowiedzi badanych, zarówno kobiet, jak i mężczyzn, uwzględnimy wiek, okazuje się, że osoby młode, w średnim wieku i stare wskazują na nieco inne działania szkodzące ich zdrowiu. W pierwszej kolejności zostaną omówione różnice w wypowiedziach względem 
omawianego tu przedmiotu postawy w zbiorowości kobiet (w trzech kategoriach wiekowych), następnie zaś w zbiorowości mężczyzn (również mając na uwadze trzy wyodrębnione kategorie wiekowe).

Zarówno kobiety młode, jak i reprezentantki średniego wieku najczęściej wymieniały niewłaściwe odżywianie jako zachowanie szkodzące ich zdrowiu. To one również stanowiły najliczniejszą grupę kobiet, które wskazały na spożywanie fast foodów, słodyczy oraz nieregularne posiłki. Najstarsze respondentki mówiły natomiast o braku konsekwencji w stosowaniu odpowiednich diet, które powinny mieć na uwadze ze względu na występujące dolegliwości zdrowotne (nadkwasota żołądka, wysoki cholesterol, cukrzyca). Stare kobiety zwracały również uwagę na spożywanie zbyt obfitych, jak na ich możliwości, posiłków: „Jak nieraz pofolguję sobie $\mathrm{z}$ jedzeniem, $\mathrm{z}$ którym nie powinnam, no ale $\mathrm{w}$ końcu, wie Pani, coś tam siedzi u człowieka w głowie" (KST_3_65). Należy w tym miejscu zwrócić uwagę na różnice generacyjne i style żywieniowe ludzi reprezentujących różne kategorie wiekowe. Zachowania żywieniowe ukształtowane w dzieciństwie i młodości decydują w dużej mierze o sposobie żywienia w dalszych latach życia i trudno poddają się modyfikacjom (Sochacka-Tatara, Stypuła 2010: 592). O ile starsze pokolenie przyzwyczajone jest do tradycyjnej polskiej kuchni, przyrządzanej zazwyczaj w domu, to młodsi ludzie reprezentują pokolenie, które często jada na mieście, także w popularnych sieciach fast foodowych. Można przypuszczać, że to jedna z przyczyn częstotliwości wskazań przez młodszych respondentów spożywania jedzenia tego typu. Pomimo tego że część młodszych badanych ma świadomość szkodliwości tych produktów, to zinternalizowane w procesie socjalizacji sposoby żywienia i ulubione smaki, silnie oddziałują na ich obecne style żywieniowe. Inną przyczyną są niewątpliwie spoty reklamowe tego typu żywności, skierowane zwłaszcza do młodych ludzi i asocjowane z określonym stylem życia.

Tylko młode kobiety oraz kobiety w średnim wieku wskazywały na stresujące sytuacje jako wpływające na ich stan zdrowia. Badane z najstarszej grupy wiekowej nie zwróciły uwagi na to działanie antyzdrowotne. O ile najmłodsze rozmówczynie wiązały stres $\mathrm{z}$ aktywnością zawodową, o tyle kobiety będące w średnim wieku zwróciły uwagę na negatywny dla ich zdrowia wpływ stresu związanego przede wszystkim z łączeniem ról rodzinnych i zawodowych, czasami przerastających, w ich odczuciu, ich siły i możliwości. Jak już wspomniano w poprzednich podrozdziałach, to przede wszystkim kobiety odpowiedzialne są za opiekę nad dziećmi i prace w gospodarstwie domowym (Titkow, Duch-Krzystoszek, Budrowska 2004).

Kobiety, bez względu na wiek, wspominały także o nieodpowiedniej długości snu jako działaniu szkodzącym ich zdrowiu. Również 
w przypadku tej deklaracji mamy do czynienia różnicami w obrębie badanych kategorii wiekowych. Młode kobiety wskazywały tu na nadmierną aktywność zawodową i przepracowywanie się jako przyczynę problemów ze snem. Część z nich wspomniała również o nadmiernym imprezowaniu jako działaniu, które negatywnie wpływa na higienę snu, tym samym na zdrowie. Kobiety będące w średnim wieku nawiązywały nie tylko do aktywności zawodowej, ale także różnego rodzaju obowiązków domowych (m.in. sprzątanie, opieka na dziećmi), które zajmują im wiele czasu i wpływają na nieregularny bądź zbyt krótki sen. Kobiety starsze zaś ilość snu wiązały z realizowaniem takich aktywności jak czytanie książek, oglądanie telewizji w godzinach nocnych. Wskazane różnice wynikały przede wszystkim z etapów życia, na których znajdowały się rozmówczynie, związanych z realizowaniem określonych ról społecznych i wypełnianiem specyficznych obowiązków.

Stosowanie substancji psychoaktywnych także uzależnione jest od wieku badanych. Większość kobiet zadeklarowała spożywanie alkoholu przy okazji spotkań towarzyskich i imprez okolicznościowych, jednak to młodsze rozmówczynie częściej przyznawały się do tego typu antyzdrowotnego zachowania, rzadziej kobiety w średnim wieku i starsze. Badane reprezentujące najstarszą kategorię wiekową w większości zadeklarowały całkowitą rezygnację z picia alkoholu. Stwierdzono również zależność pomiędzy paleniem papierosów a wiekiem. Młode kobiety przyznawały się do okolicznościowego palenia papierosów, natomiast kobiety w średnim wieku (nieliczne) wskazały, że są nałogowymi palaczkami. Jak wynika z ogólnopolskich badań poświęconych zachowaniom antyzdrowotnym Polaków, w tym paleniu papierosów, najrzadziej palą osoby starsze, powyżej 65 roku życia (13\%) oraz młode - między 25 a 34 rokiem życia (26\%). Największą popularnością papierosy cieszą się wśród osób w średnim wieku, czyli mających od 35 do 54 lat (40\%). Niemal we wszystkich grupach wiekowych zdecydowanie częściej palą mężczyźni niż kobiety, z wyjątkiem osób w wieku 18-24 lata, wśród których przeważają palaczki (CBOS 2012d). Mimo że mężczyzn częściej charakteryzują opisane wzory zachowań, to proces androgynizacji kobiet (odbywający się na różnych poziomach życia społecznego, także w aspekcie zachowań zdrowotnych) w społeczeństwach wysoko rozwiniętych sprawia, iż młode kobiety coraz częściej sięgają po substancje psychoaktywne.

Charakterystyczne dla reprezentantek średniego wieku było niepodejmowanie aktywności fizycznej, lekceważenie objawów chorobowych i niewykonywanie badań profilaktycznych jako działań szkodzących ich zdrowiu. Kobiety te tłumaczyły swoje zachowania przede wszystkim nadmiarem obowiązków i brakiem czasu aby zająć się sobą i swoim zdrowiem, a także strachem przed wykryciem ewentualnej choroby. Jak już 
wspomniano w rozdziale dotyczącym powodów dbania o zdrowie, reprezentantki średniego wieku nawiązują do genderowo określonych kobiecych powinności (obowiązku dbania o zdrowie, nie tylko swoje, ale także najbliższych, opieki nad dziećmi oraz łączenia pracy zawodowej z obowiązkami domowymi). Można je również zakwalifikować do wspomnianego już „pokolenia przegubowego"/,sandwich generation”, żyjącego niejako „w kanapce" i rozdartego pomiędzy opieką nad starszymi rodzicami, a własnymi dziećmi bądź wnukami (Diller 2012). Uwikłanie w genderowo (patriarchalnie) określone powinności powoduje, że wielu reprezentantkom średniego wieku brakuje czasu, żeby zadbać o swoje zdrowie.

Specyficzne dla kobiet starszych było zaś wskazywanie na brak działań antyzdrowitnych. Reprezentantki tej kategorii wiekowej częściej deklarowały pozytywne zachowania zdrowotne niż takie, które mogą szkodzić ich zdrowiu.

Analizując wypowiedzi mężczyzn należących do trzech kategorii wiekowych na temat podejmowanych przez nich zachowań antyzdrowotnych, również $\mathrm{w}$ tym przypadku dostrzeżono pewne różnice $\mathrm{w}$ ich stosunku do omawianego przedmiotu postawy.

Mężczyźni młodzi i będący w średnim wieku wskazywali na spożywanie jedzenia typu fast food oraz dużej ilości słodyczy (na takie działania szkodzące zdrowiu nie zwracali uwagi najstarsi respondenci). Jeśli chodzi o nieodpowiednie jedzenie, to charakterystycznym dla mężczyzn w średnim wieku oraz mężczyzn starych było spożywanie produktów ciężkostrawnych, tłustych, tzw. tradycyjnej kuchni polskiej: „[...] lubię rzeczy dobre i tłuste, które, no tak jak mówię, typowa polska kuchnia, kapusta, jakieś tłuste żeberka czy golonka" (MST_11_71). Podobnie jak w przypadku kobiet, takie zachowania antyzdrowotne możemy również tłumaczyć różnicami generacyjnymi, dotyczącymi stylów żywieniowych osób będących w różnym wieku.

Jeśli chodzi o kolejne zachowania antyzdrowotne, na które wskazywali mężczyźni - stosowanie substancji psychoaktywnych (palenie papierosów oraz spożywanie napojów alkoholowych), to i w tym przypadku wystąpiły różnice pomiędzy reprezentantami poszczególnych kategorii wiekowych. Jak wynika z ogólnopolskich badań dotyczących omawianego zachowania antyzdrowotnego, pomimo tego że popularność palenia jest bardzo silnie zróżnicowana ze względu na płeć (wśród kobiet pali $21 \%$, a wśród mężczyzn palacze stanowią 40\%), to istotnym czynnikiem jest również wiek. Najrzadziej palą respondenci najmłodsi (18-24 lata) i najstarsi (65 lat i więcej). Również wśród naszych badanych, to młodzi mężczyźni i mężczyźni starzy rzadziej niż mężczyźni w średnim wieku deklarowali palenie papierosów. W przypadku młodych mężczyzn takie zachowania można wytłumaczyć m.in. współczesną modą na niepalenie 
i niejednokrotnie wspomniany zdrowy styl życia (healthism), natomiast mężczyźni starzy rezygnują $\mathrm{z}$ palenia papierosów przede wszystkim ze względów zdrowotnych oraz finansowych.

Jeśli chodzi o spożywanie napojów alkoholowych, to w przypadku mężczyzn nie zauważono znaczących różnic w trzech kategoriach wiekowych. Zarówno mężczyźni młodzi, w średnim wieku, jak i starzy, wskazywali na omawiane zachowanie szkodzące ich zdrowiu. Badani wspominali, że spożywają alkohol przeważnie podczas imprez bądź spotkań towarzyskich:

[...] jeżeli chodzi nawet o takie przyjemności jak dobry alkohol. Nie wiem, czy pan też lubi, ale chyba wszyscy lubią dobry alkohol. [...] bardzo lubię whisky na przykład sobie od czasu do czasu szklaneczkę wypić. I doszedłem do tego momentu, że stwierdziłem, że w tym wieku już należy, na przykład tak jak kiedyś wszyscy się śmiali, że taka przysłowiowa dawka była taka, jak spotkaliśmy się, kiedyś jak wszyscy byliśmy jeszcze młodsi, to ta półlitrowa butelka to była na osobę. To teraz mam taką normę, której nie przekraczam, to ćwiartka i wiem, że jak tego nie przekroczę, to na drugi dzień czuję się doskonale. A osiągnąłem to w taki sposób, że zamiast pić cały kieliszek, to piję pół. I naprawdę przychodzę do domu, świetnie się czuję i na drugi dzień w ogóle nie ma żadnego problemu. Jeszcze zdarza się, że gdzieś na przykład $\mathrm{w}$ niedzielę pojechać samochodem, to sobie potwierdzam to alkomatem i jest wszystko ok. I to jest takie świadome działanie, żeby na drugi dzień, brzydko mówiąc, nie zdychać. Co się zdarzało kiedyś (MST_5_64). [...] picie alkoholu nie jest korzystne dla zdrowia, generalnie. Ale, jak powiedziałem, lubię sobie, zwłaszcza w gronie przyjaciół wypić, i to nie jednego głębszego, tylko kilka, prawda. Ale na to też zwracam uwagę, bo to jest przyjemność bycia razem i ten alkohol jest jakimś czynnikiem do ciekawej, fajnej rozmowy, do, no prostu, do bycia wspólnie, przeżywania czegoś fajnie. Nie jest celem. Natomiast wiadomo, że każde doświadczenie nadmierne $\mathrm{z}$ alkoholem, no to wiesz tam, czy głowa boli, ale to są takie oczywistości, że trudno nawet o tym mówić (MST_4_64).

Jak wynika z powyższych wypowiedzi, spożywanie alkoholu podczas różnego rodzaju spotkań towarzyskich stanowi normę w naszej kulturze. Męskość od wieków kojarzona jest $\mathrm{z}$ używaniem tego typu substancji psychoaktywnych. A. Ostrowska podkreśla, że „Wzór kulturowy wskazuje, co jest właściwe i niewłaściwe dla mężczyzn i kobiet w takich kwestiach jak palenie papierosów (choć ostatnio różnice zacierają się tu coraz bardziej) i picie alkoholu. Pijana kobieta wyzwala znacznie więcej niechęci i krytyki społecznej niż pijany mężczyzna" (Ostrowska 2006: 117).

Niepodejmowanie aktywności fizycznej jako działanie antyzdrowotne było wskazywane zwłaszcza przez mężczyzn młodych i będących w średnim wieku. Uzasadniając swoją bierność, mężczyźni odwoływali się 
zwłaszcza do czynników zewnętrznych - braku czasu, zaangażowania w życie zawodowe. Charakterystyczne dla reprezentantów średniego wieku było również ograniczanie bądź zaprzestanie aktywności fizycznej ze względów zdrowotnych. Mężczyźni starzy nie zwracali uwagi na ten rodzaj działania szkodzącego ich zdrowiu. Nawiązując do wcześniej omówionego aspektu (zachowań prozdrowotnych), starsi rozmówcy nie podejmują także aktywności fizycznej, tak często jak młodsi badani. Jak wynika z badań ogólnopolskich, wraz z wiekiem obserwowany jest spadek aktywności w zakresie wszystkich form rekreacji fizycznej (CBOS 2013a).

Niewykonywanie badań profilaktycznych oraz lekceważenie objawów chorobowych również wskazywane było przez mężczyzn młodych i będących w średnim wieku. O zachowaniach tych nie wspominali reprezentanci najstarszej kategorii wiekowej. Występujące różnice generacyjne wynikały m.in. $\mathrm{z}$ zaangażowania w pełnione role w życiu prywatnym i publicznym (np. student, pracownik) i braku czasu ze względu na różnego rodzaju zobowiązania z nimi związane. Starzy mężczyźni ze względu na występowanie różnych problemów zdrowotnych niejako byli zmuszeni do ich niwelowania, m.in. przeprowadzania badań, wizyt lekarskich. Jak już wspomniano, bardzo często za namową swoich bliskich (żon, córek). Wskazane różnice wynikają przede wszystkim $z$ określonych etapów życia, na których znajdują się mężczyźni, a także ich stanu zdrowia. Niebagatelne znaczenie ma również, wspomniany już wcześniej, funkcjonujący w naszej kulturze stereotyp roli mężczyzny w społeczeństwie i rodzinie. Mężczyzna nie choruje, nie skarży się na różnego rodzaju dolegliwości oraz nie chodzi do lekarza.

Jedynie mężczyźni będący w średnim wieku zwrócili uwagę na znaczenie przepracowywania się jako działania antyzdrowotnego. I w tym przypadku zależnego od określonego etapu życia, na którym znajduje się jednostka. Tylko część młodych badanych była aktywna zawodowo (niektórzy z nich jeszcze uczyli się/studiowali), także tylko nieliczni reprezentanci najstarszej kategorii wiekowej pracowali. Zawodowa aktywność odgrywała kluczowe znaczenie $\mathrm{w}$ przypadku wskazania wspomnianego działania antyzdrowotnego. Jak już nadmieniono, centralnym punktem patriarchalnej koncepcji męskości jest właśnie aktywność zawodowa, na którą mężczyźni poświęcają więcej czasu niż kobiety. Ten istotny element życia mężczyzny przyczynia się także do kształtowania jego zdrowotnej postawy. Mężczyźni będący w średnim wieku wiedli prym we wskazywaniu różnego typu zachowań antyzdrowotnych, także braku wytrwałości w dbaniu o zdrowie. Jak sami zauważyli, kobiety są stworzone do dbania o zdrowie, nie tylko swoje, ale także najbliższych. Przykłady opieki ze strony żon/partnerek bądź córek pojawiały się w każdej kategorii wiekowej badanych, natomiast najliczniej wśród najstarszych mężczyzn. 
Część z nich zadeklarowała również brak działań antyzdrowotnych. Z ich wypowiedzi wynika, że nie czynią nic, co mogłoby szkodzić ich zdrowiu, ponieważ są pod opieką bliskich, a w związku z tym nie mają sposobności do zachowań antyzdrowotnych: „Tak, oczywiście. Myślę, że my dbamy. Tzn. ja z żoną. No ona może bardziej, bo na tę tarczycę też choruje, ale ja też. Ona mnie też zawsze przypilnuje. $\mathrm{Z}$ tymi ziołami, z dietą [...]" (MST_8_70).

Nawiązując do postawionych hipotez, kobiety rzadziej niż mężczyźni szkodzą swojemu zdrowiu, a także, jak już zostało wskazane w poprzednim podrozdziale, częściej niż mężczyźni są aktywniejsze w dbaniu o nie. Biorąc pod uwagę „upłciowiony wiek”, kobiety i mężczyźni reprezentujący różne kategorie wiekowe wskazują na nieco inne działania szkodzące ich zdrowiu. Najbardziej podobni w swoich deklaracjach byli młodzi ludzie. Zarówno młode kobiety, jak i młodzi mężczyźni wskazywali na te same zachowania negatywnie wpływające na ich zdrowie. Różnica dotyczyła przede wszystkim spożywania alkoholu - młodzi mężczyźni częściej niż ich rówieśniczki przyznawali się do tego typu antyzdrowotnego zachowania, wypijali również większe ilości tego typu napojów. Jak już zauważono, w polskim społeczeństwie istnieje mniejsze przyzwolenie dla kobiet palących papierosy czy spożywających wysokoprocentowe napoje alkoholowe. Należy tu również przypomnieć, że kobiety, częściej niż mężczyźni, uświadamiane są w zakresie szkodliwości stosowania substancji psychoaktywnych. Ta zróżnicowana siła prozdrowotnych presji społecznych przekłada się zatem na podejmowanie przez kobiety i mężczyzn określonych zachowań pro- i antyzdrowotnych. 